CARLOS ORLANDI CHAGAS

NOVOS DEFEITOS DO NEGÓCIO JURÍDICO

TESE DE DOUTORADO

TITULAR CARLOS ALBERTO DABUS MALUF

FACULDADE DE DIREITO

UNIVERSIDADE DE SÃO PAULO

SÃo PAULO

2014 


\title{
NOVOS DEFEITOS DO NEGÓCIO JURÍDICO
}

Tese apresentada à Banca de Doutorado na Faculdade de Direito da Universidade de São Paulo como exigência para aprovação no Programa de Pós-Graduação na Área de Concentração Direito Civil.

FACULDADE DE DIREITO

UNIVERSIDADE DE SÃO PAULO

\author{
SÃO PAULO
}

2014 
Dedico este trabalho ao Professor Rui Geraldo Camargo Viana, conspícuo mestre, denodado pensador e inexcedivel amigo. 


\section{INDICE}

Introdução

Capítulo I - Aspectos Gerais do Negócio Jurídico

1. O Fato Jurídico

a) Direito

b) Classificação

2. O Negócio Jurídico

a) As Teorias

- Subjetiva

- Objetiva

b) Definição

c) Os Planos da Existência, Validade e Eficácia

d) A Interpretação

Capítulo II - O Negócio Jurídico no Direito Romano

Capítulo III - O Negócio Jurídico no Direito Brasileiro

Capítulo IV - Os Defeitos do Negócio Jurídico 


\section{INTRODUÇÃO}

O tema pertinente à disciplina do negócio jurídico, tratado no velho Código Bevilaqua tão somente como ato jurídico - em clara adesão à corrente unitarista, atualmente superada pela posição dualista -, especialmente no que concerne aos seus defeitos ou vícios, já foi sobejamente estudado pela doutrina clássica brasileira e estrangeira, bem como fartamente enfrentado pela jurisprudência dos tribunais pátrios.

A despeito dessa evidência, o assunto ainda merece maior reflexão e aprofundamento em razão das alterações - mesmo que pontuais em relação a certos institutos - trazidas a lume pelo Código Civil de 2002. Além do mais, com a edição do novo Estatuto do Homem Comum, aos conhecidos defeitos do ato jurídico, foram agregados os novos defeitos do negócio jurídico, hipóteses jurídicas antes não previstas, pelo menos, no âmbito normativo.

São esses "novos" institutos do direito civil, o estado de perigo e a lesão que se pretende investigar as origens e a disciplina a eles conferida pelo doutrina civilista clássica, assim como apurar o tratamento que receberam na jurisprudência nacional mesmo ainda sob a vigência do velho Código Civil de 1916, mas sobretudo após a edição do Código Civil de 2002.

Não se pretende, por óbvio, esgotar toda a problemática ligada ao tema, sendo bem certo que cada um dos novéis institutos mereceria um estudo autônomo. O que se busca, porém, é exclusivamente aprofundar os principais contrastes e inovações, dentro da "nova" sistemática fixada pelo novo Código Civil, quando confrontada com os paradigmas do velho Código Bevilaqua.

Especial destaque se procura conferir ao enfrentamento dos termas pertinentes aos novos defeitos do negócio jurídico na jurisprudência do Supremo Tribunal Federal e do Superior Tribunal de Justiça, de modo a se poder constatar que grau de evolução a entrada em vigor do novo diploma do direito civil conferiu à práxis desses "jovens" institutos jurídicos. 


\section{CAPÍTULO I - ASPECTOS GERAIS DO NEGÓCIO JURÍDICO}

\section{O Fato Jurídico}

Os eventos resultado da atividade humana ou fruto de fatos da natureza que possam interferir na seara do direito, ou seja, sobre os quais incida norma jurídica suficiente a criar, transferir, conservar, modificar ou extinguir relações jurídicas, são tradicionalmente denominados fatos jurídicos ${ }^{l}$.

Diferente, contudo, do que se extrai da velha parêmia ex facto oritur ius ${ }^{2}$, o direito como norma positiva não deriva dos fatos, mas do próprio ordenamento jurídico que qualifica determinados fatos como jurídicos ${ }^{3}$, sendo verdade que esses fatos

Silvio Rodrigues, Direito Civil - Parte Geral, 34ª ed., São Paulo, Saraiva, 2007, pp. 155 e 156 : "Assim, a expressão fatos jurídicos, em seu sentido amplo, engloba todos aqueles eventos, provindos da atividade humana ou decorrentes de fatos naturais, capazes de ter influência na órbita do direito, por criarem, ou transferirem, ou conservarem, ou modificarem, ou extinguirem relações jurídicas".

2 Caio Mário da Silva PereIRA, Instituições de Direito Civil - Introdução ao Direito Civil - Teoria Geral do Direito Civil, vol. I, 23 ${ }^{\mathrm{a}}$ ed. atual. por Maria Celina Bodin de Moraes, Rio de Janeiro, Forense, 2010, p. 391:

"O direito origina-se do fato, como na parêmia se dizia: ex facto ius oritur. O fato é o elemento gerador do direito subjetivo mesmo quando se apresenta tão singelo que mal se perceba, mesmo quando ocorra dentro do ciclo rotineiro das eventualidades quotidianas, de que todos participam sem darem atenção. A lei comumente define uma possibilidade, um vir a ser, que se transformará em direito mediante a ocorrência de um acontecimento que converte a potencialidade de um interesse em direito individual".

Como adiante se demonstrará, contudo, à luz da Teoria Pura do Direito de H. KELSEN, o fato da ordem do ser é suficiente para caracterizar o direito, sendo-lhe conditio sine qua nom, todavia o seu fundamento deriva do próprio ordenamento jurídico, isto é, de uma norma jurídica superior que prescreva aquele indigitado fato como suficiente a interferir na órbita do direito, sendo esta norma superior conditio per quam para a validade do fato jurídico entendido em última análise como norma jurídica.

H. KELSEN, Reine Rechtslehre, 1934, trad. port. de J. Cretella Jr. e Agnes Cretella, Teoria Pura do Direito - Introdução à Problemática Científica do Direito - Versão Condensada pelo Próprio Autor, $4^{\text {a }}$ ed., São Paulo, RT, 2006, p. 95:

"Diferentes são as normas de direito. Estas não valem por causa do conteúdo. Todo e qualquer conteúdo pode ser direito. Não existe conduta humana que, como tal, por sua essência, esteja excluída de tornar-se o conteúdo de uma norma jurídica. Sua validade não pode ser, por isso, questionada se seu conteúdo não corresponder a um valor material ou moral de algum modo estabelecido. Uma norma vale como norma jurídica apenas porque foi estabelecida de modo bem determinado, criada segundo uma regra bem determinada e estabelecida de acordo com um método específico". Negritou-se.

3 H. KELSEN, Reine Rechtslehre, 1934, trad. port. de J. Cretella Jr. e Agnes Cretella, Teoria Pura do Direito - Introdução à Problemática Científica do Direito - Versão Condensada pelo Próprio Autor, $4^{\mathrm{a}}$ ed., São Paulo, RT, 2006, p. 53:

"Se alguém analisar qualquer estado de coisas (Sachverhalte) considerado como direito, como, por exemplo, uma deliberação do Parlamento, um ato administrativo, uma sentença judicial, um delito, podem distinguir-se dois elementos: um deles é um ato no tempo e no espaço, um ato perceptível 
jurídicos ostentam dois fatores constitutivos: o fato, da ordem do ser, e a sua prescrição pela ordem do dever ser como sendo ele capaz de interferir na órbita jurídica ${ }^{4}$, tudo conformando um silogismo lógico.

Preponderando a repercussão na órbita do direito que o fato jurídico tem o condão de ocasionar, ele se diferencia do que a doutrina convencionou nominar de fatos materiais, consistentes naqueles acontecimentos naturais e derivados da conduta humana que não repercutem na seara jurídica, ou seja, independente do seu conteúdo, deles não pulula nenhum efeito jurídico, porque do ordenamento não lhes incide nenhuma prescrição normativa ${ }^{5}$.

\section{a) Direito}

Acerca do conceito de direito, costuma-se estabelecer a dicotomia entre o direito objetivo e o direito subjetivo, designando o primeiro o conjunto de normas postas enquanto regras para prescrever como deve ser o comportamento humano (norma agendi), e o segundo, a faculdade que deriva da norma objetiva para determinados sujeitos recobrarem determinado comportamento prescrito (facultas agendi), de conformidade com a sua vontade e os seus interesses, ambos sempre assegurados pelo ordenamento ${ }^{6}$.

sensorialmente, um acontecimento exterior, sendo na maior parte comportamento humano; o outro, é, um ato ou acontecimento (fato) igualmente inerente ou ligado a um sentido, a um significado específico".

4 Caio Mário da SILVA PereIRA, Instituições de Direito Civil - Introdução ao Direito Civil - Teoria Geral do Direito Civil, vol. I, 23 ${ }^{\mathrm{a}}$ ed. atual. por Maria Celina Bodin de Moraes, Rio de Janeiro, Forense, 2010, p. 392:

"Ontologicamente considerado, o fato jurídico se biparte em dois fatores constitutivos: de um lado, um fato, ou seja, uma eventualidade de qualquer espécie, que se erige em causa atuante sobre o direito subjetivo, quer gerando-o, quer modificando-o, quer extinguindo-o; de outro lado, uma declaração do ordenamento jurídico, atributiva de efeito àquele acontecimento. Sem esta última, o fato não gera o direito subjetivo; sem o acontecimento, a declaração da lei permanece em estado de mera potencialidade. A conjugação de ambos, eventualidade e preceito legal, é que compõe o fato jurídico (Oertmann)".

5 José Abreu, O Negócio Jurídico e a sua Teoria Geral, $2^{\mathrm{a}}$ ed., São Paulo, Saraiva, 1988, p. 4:

"(...) Distingue, contudo, a doutrina, preliminarmente, os fatos jurídicos de uma outra categoria de eventos que se convencionou chamar de fatos materiais. Nesta indagação não importaria, absolutamente, a natureza intrínseca do fato, nem sua origem. Assim, um mesmo acontecimento poderia ser jurídico ou material, diferenciando-se um do outro pela produtividade de efeitos jurídicos, peculiar ao primeiro e inexistente no segundo. A natureza do fato, sua procedência, será irrelevante. Indaga-se, tão-somente, se repercute ou não juridicamente. Na hipótese afirmativa, será fato jurídico; fato material será na segunda hipótese".

6 Washington de BARros MonteIro - Ana Cristina de Barros Monteiro FrançA Pinto, Curso de Direito Civil - Parte Geral, vol. 1, 42a ed., São Paulo, Saraiva, 2010, pp. 4 e 5: 
H. KELSEN, porém, ao fixar a sua Teoria Pura do Direito, propondo-se a libertar a ciência jurídica de tudo quanto fosse estranho ao seu objeto: o direito ${ }^{7}$, define este como sendo o conjunto das normas jurídicas que atribuem a determinados fatos externos e sensorialmente perceptíveis - porque realizados no espaço e no tempo - o caráter de fatos jurídicos, na medida em que coincidem o objeto dos primeiros - a conduta humana - com o conteúdo prescrito pela norma jurídica correspondente. Tal conclusão se atinge porque, para a teoria pura, a norma funciona como esquema de interpretação por meio do qual se empresta à conduta humana, além do sentido subjetivo que lhe impregna o seu agente (intenção ligada ao fato externo pelo sujeito), também um sentido objetivo, ou seja, o significado do ato externo do ponto de vista do direito posto ou a significação jurídica do seu conteúdo, porque coincidente com a prescrição normativa válida ${ }^{8}$.

"Direito objetivo é a regra de direito, a regra imposta ao proceder humano, a norma de comportamento a que o indivíduo deve se submeter, o preceito que deve inspirar sua atuação. À respectiva observância pode ser compelido mediante coação. $\mathrm{O}$ direito objetivo designa o direito enquanto regra (jus est norma agendi).

Direito subjetivo é poder. São as prerrogativas de que uma pessoa é titular, no sentido de obter certo efeito jurídico, em virtude da regra de direito. A expressão designa apenas uma faculdade reconhecida à pessoa pela lei e que lhe permite realizar determinados atos. É a faculdade que, para o particular, deriva da norma (jus est facultas agendi).

Por outras palavras, direito objetivo é o conjunto das regras jurídicas; direito subjetivo é o meio de satisfazer interesses humanos (hominum causa omne jus constitutum est). $\mathrm{O}$ segundo deriva do primeiro". Negritou-se.

7 H. KELSEN, Reine Rechtslehre, 1960, trad. port. de João Baptista Machado, Teoria Pura do Direito, $6^{\text {a }}$ ed., São Paulo, Martins Fontes, 1998, p. 1:

"A Teoria Pura do Direito é uma teoria do Direito positivo - do Direito positivo em geral, não de uma ordem jurídica especial. É teoria geral do Direito, não interpretação de particulares normas jurídicas, nacionais ou internacionais. Contudo, fornece uma teoria da interpretação.

Como teoria, quer única e exclusivamente conhecer o seu próprio objeto. Procura responder a esta questão: o que é e como é o Direito? Mas já não lhe importa a questão de saber como deve ser o Direito, ou como deve ele ser feito. É ciência jurídica e não política do Direito.

Quando a si própria se designa como 'pura' teoria do Direito, isto significa que ela se propõe garantir um conhecimento apenas dirigido ao Direito e excluir deste conhecimento tudo quanto não pertença ao seu objeto, tudo quanto não se possa, rigorosamente, determinar como Direito. Quer isto dizer que ela pretende libertar a ciência jurídica de todos os elementos que lhe são estranhos. Esse é o seu princípio metodológico fundamental". Negritou-se.

8 H. KELSEN, Reine Rechtslehre, 1960, trad. port. de João Baptista Machado, Teoria Pura do Direito, $6^{\text {a }}$ ed., São Paulo, Martins Fontes, 1998, p. 4:

"O fato externo que, de conformidade com o seu significado objetivo, constitui um ato jurídico (lícito ou ilícito), processando-se no espaço e no tempo, é, por isso mesmo, um evento sensorialmente perceptível, uma parcela da natureza, determinada, como tal, pela lei da causalidade. Simplesmente, este evento como tal, como elemento do sistema da natureza, não constitui objeto de um conhecimento especificamente jurídico - não é, pura e simplesmente, algo jurídico. O que transforma este fato num ato jurídico (lícito ou ilícito) não é a sua facticidade, não é o seu ser natural, isto é, o seu ser tal como determinado pela lei da causalidade e encerrado no sistema da natureza, mas o sentido objetivo que está ligado a esse ato, a significação que ele possui. O sentido jurídico específico, a sua particular significação jurídica, recebe-a o fato em questão por intermédio de uma norma que a ele se refere com o 
Em outras palavras, o direito, objeto da ciência jurídica, é o conjunto de normas que conferindo significado objetivo aos fatos externos, tornando-os fatos jurídicos, estabelece um sistema capaz de regular a conduta dos homens em sociedade ${ }^{9}$.

No âmbito da doutrina brasileira, aproxima-se dessa posição SAN TIAGO DANTAS, para quem o objeto de trabalho do jurista é o direito evidenciado como um complexo de normas positivas. Dedica-se a ciência jurídica ao fenômeno da norma posta e não a empreender conjecturas de caráter político ou sociológico acerca de como melhor ou pior seria posta a mesma norma jurídica ${ }^{10}$.

Nessa medida, a positividade indispensável às normas jurídicas, na visão do autor brasileiro, adquire dois contornos essenciais: a exterioridade e a coercibilidade. A primeira característica esclarece que as prescrições normativas somente podem dizer respeito à conduta externa do indivíduo dentro do grupo social, mas não a ações mentais ou de caráter mental, esterilizando da incidência do direito positivo os chamados propositum in mente retentum de que cuidava o direito canônico medieval. Já a coercibilidade vem distinguir o direito de outras normas que também ditam

seu conteúdo, que lhe empresta a significação jurídica, por forma que o ato pode ser interpretado segundo esta norma. A norma funciona como esquema de interpretação. Por outras palavras: o juízo em que se enuncia que um ato de conduta humana constitui um ato jurídico (ou antijurídico) é o resultado de uma interpretação específica, a saber, de uma interpretação normativa. Mas também na visualização que o apresenta como um acontecer natural apenas se exprime uma determinada interpretação, diferente da interpretação normativa: a interpretação causal. A norma que empresta ao ato o significado de um ato jurídico (ou antijurídico) é ela própria produzida por um ato jurídico, que, por seu turno, recebe a sua significação jurídica de uma outra norma. (...)". Negritou-se.

9 H. KELSEN, Reine Rechtslehre, 1960, trad. port. de João Baptista Machado, Teoria Pura do Direito, $6^{\text {a }}$ ed., São Paulo, Martins Fontes, 1998, p. 5:

"Ora, o conhecimento jurídico dirige-se a estas normas que possuem o caráter de normas jurídicas e conferem a determinados fatos o caráter de atos jurídicos (ou antijurídicos). Na verdade, o Direito, que constitui o objeto deste conhecimento, é uma ordem normativa da conduta humana, ou seja, um sistema de normas que regulam o comportamento humano. Com o termo 'norma' se quer significar que algo deve ser ou acontecer, especialmente que um homem se deve conduzir de determinada maneira. (...)".

10 Francisco Clementino de San Tiago Dantas, Programa de Direito Civil - Aulas proferidas na Faculdade Nacional de Direito [1942-1945] - Parte Geral, 2a ed., Rio de Janeiro, Rio, 1979, p. 26:

"Aos olhos do jurista, o direito nada mais é que um complexo de normas jurídicas, uma massa de comandos, esse é que é o seu material fenomenológico.

Quando o físico se prepara para os seus estudos, que procura ele estudar? Os fenômenos físicos que ele contempla em torno de si, do mesmo modo que o naturalista as espécies vivas, o sociólogo os fatos sociais. E o jurista que trata de conhecer? Trata de conhecer as normas jurídicas. As normas jurídicas são os seus fenômenos e isto que pode parecer a alguns uma verdade elementar é uma verdade à qual fogem muitos espíritos. Muita gente pensa que não, que o jurista estuda a sociedade por um ângulo jurídico, isto é, com uma perspectiva de política e sociologia, mas o jurista só toma conhecimento do fenômeno quando a norma jurídica já está elaborada, quando agora é que começa o trabalho do jurista". 
comportamentos no âmbito do convívio social, porém sem o condão de impingir aos seus transgressores por meio de uma autoridade estatal a sua fiel observância ou a sujeição a outra disposição normativa equivalente ${ }^{11}$.

A produção normativa, retomando a visão de KELSEN, constitui-se de um ato de vontade de determinado indivíduo, quem expressa um dever ser com escopo de fixar regra sobre determinada conduta humana, mas para que esse dever ser em sentido subjetivo (ato de vontade) adquira a validade de uma nova norma jurídica é necessário que outra norma jurídica superior e preexistente lhe confira essa significação, ou seja, conceda ao mesmo dever ser o seu sentido objetivo ou normativo. Desse modo, a validade da norma produzida deriva tão somente do sentido objetivo conferido ao dever ser pela norma superior, a qual conferiu ao ato de vontade (dever ser em sentido subjetivo) significado jurídico (dever ser em sentido objetivo), o que também explica que desaparecendo a intenção subjetiva, a vontade expressa ou até mesmo o próprio agente do fato externo, permanece hígida a norma produzida ${ }^{12}$. Da mesma forma que o

Francisco Clementino de SAn Tiago Dantas, Programa de Direito Civil - Aulas proferidas na Faculdade Nacional de Direito [1942-1945] - Parte Geral, 2ª ed., Rio de Janeiro, Rio, 1979, p. 39:

"Esta noção de uma positividade do direito envolve numerosas doutrinas de que se precisa, apesar da índole da nossa cadeira, tomar consciência. Por exemplo, Jhering, já conhecido bem e que foi realmente um dos grandes espíritos do mundo jurídico no século XIX, definiu as características do direito de um modo preciso com estas duas palavras: o direito se caracteriza pela exterioridade e pela coercibilidade e que constituem o que chamamos a positividade do direito.

Que é a exterioridade? A exterioridade significa que o comando jurídico refere-se sempre a uma ação externa do homem; não pode se referir a um ato de consciência; não pode se referir a um propósito mental.

O propositum in mente retentum, de que falava tanto o direito eclesiástico na Idade Média, não constitui objeto de ação das normas jurídicas. As normas de direito só se referem à conduta externa do homem e isto é um importante elemento de diferenciação entre o direito e a moral. Enquanto a moral se refere à conduta externa e à conduta interna, o direito só se refere à conduta externa, para ele é irrelevante o domínio da consciência.

A outra característica é a coercibilidade. Tem-se numerosas normas que regulam a vida da sociedade mas que não fazem parte do tecido da ordem jurídica. São comandos que se dirigem a todos os cidadãos, mas, ou fazem parte da ordem moral, ou fazem parte mesmo dos simples bons costumes; não entram na ordem jurídica. Cumprimentar os conhecidos, felicitá-los no dia do seu aniversário, por exemplo, são normas universais, mas não são normas jurídicas, (...) ao passo que a norma jurídica, essa tem como sua característica mesmo a coercibilidade, o que quer dizer que, se alguém quiser se furtar à ação da norma jurídica, há uma autoridade capaz de impor ou o cumprimento da norma, ou o cumprimento de uma norma equivalente; ou é a própria norma que se cumpre ou então desaparece esta e surge uma outra que o Estado está em condições de impor".

H. KELSEN, Reine Rechtslehre, 1960, trad. port. de João Baptista Machado, Teoria Pura do Direito, $6^{\text {a }}$ ed., São Paulo, Martins Fontes, 1998, pp. 8 e 9:

"A circunstância de o 'dever-ser' constituir também o sentido objetivo do ato exprime que a conduta a que o ato intencionalmente se dirige é considerada como obrigatória (devida), não apenas do ponto de vista do indivíduo que põe o ato, mas também do ponto de vista de um terceiro desinteressado - e isso muito embora o querer, cujo sentido subjetivo é o dever-ser, tenha deixado faticamente de existir, uma vez que, com a vontade, não desaparece também o sentido, o dever-ser; 
ato de vontade, também o costume perpetrado na sociedade pode em sentido subjetivo fixar condutas obrigatórias (dever ser), desde que norma superior lhe confira em sentido objetivo significação jurídica e assim nessa norma jurídica preexistente a nova regra consuetudinária buscará a sua validade, sem perdê-la mesmo que mais tarde o costume que a caracterizou tão somente paire no consciente coletivo ${ }^{13}$.

É exatamente desse processo produtivo que também deriva o conceito de vigência como sendo a existência específica da norma jurídica, portanto independente do ato de vontade ou da conduta costumeira que inicialmente lhe conferiu sentido fático subjetivo. A norma jurídica encontra-se na órbita do dever ser, donde também subtrai sua validade e vigência, ou seja, de outra norma que lhe confere significado jurídico objetivo $^{14}$.

uma vez que o dever-se 'vale' mesmo depois de a vontade ter cessado, sim, uma vez que ele vale ainda que o indivíduo cuja conduta, de acordo com o sentido subjetivo do ato de vontade, é obrigatória (devida) nada saiba desse ato e do seu sentido, desde que tal indivíduo é havi do como tendo o dever ou o direito de se conduzir de conformidade com aquele dever-ser. Então, e só então, o dever-ser, como dever-ser 'objetivo', é uma 'norma válida' ('vigente'), vinculando os destinatários. É sempre este o caso quando ao ato de vontade, cujo sentido subjetivo é um deverser, é emprestado esse sentido objetivo por uma norma, que por isso vale como norma 'superior' , atribui a alguém competência, (ou poder) para esse ato. (...) Portanto, não é do ser fático de um ato de vontade dirigido à conduta de outrem, mas é ainda e apenas de uma norma de dever-ser que de flui a validade - (...) - da norma segundo a qual esse outrem se deve conduzir em harmonia com o sentido subjetivo do ato de vontade".

13 H. KELSEN, Reine Rechtslehre, 1960, trad. port. de João Baptista Machado, Teoria Pura do Direito, $6^{\mathrm{a}}$ ed., São Paulo, Martins Fontes, 1998, p. 10:

"As normas através das quais uma conduta é determinada como obrigatória (como devendo ser) podem também ser estabelecidas por atos que constituem o fato do costume. (...) Porém, o sentido subjetivo dos atos constitutivos do costume apenas pode ser interpretado como norma objetivamente válida se o costume é assumido como fato produtor de normas por uma norma superior. Visto o fato do costume ser constituído por atos de conduta humana, também as normas produzidas pelo costume são estabelecidas por atos de conduta humana e, portanto, normas postas, isto é, normas positivas, tal como as normas que são o sentido subjetivo de atos legislativos. Através do costume tanto podem ser produzidas normas morais como normas jurídicas. As normas jurídicas são normas produzidas pelo costume se a Constituição da comunidade assume o costume - um costume qualificado - como fato criador de Direito". Negritou-se.

14 H. KELSEN, Reine Rechtslehre, 1960, trad. port. de João Baptista Machado, Teoria Pura do Direito, 6a ed., São Paulo, Martins Fontes, 1998, p. 11:

"Com a palavra 'vigência' designamos a existência específica de uma norma. Quando descrevemos o sentido ou o significado de um ato normativo dizemos que, com o ato em questão, uma qualquer conduta humana é preceituada, ordenada, prescrita, exigida, proibida; ou então consentida, permitida ou facultada. Se, como acima propusemos, empregarmos a palavra 'dever-ser' num sentido que abranja todas estas significações, podemos exprimir a vigência (validade) de uma norma dizendo que certa coisa deve ou não deve ser feita. Se designarmos a existência especifica da norma como a sua 'vigência', damos desta forma expressão à maneira particular pela qual a norma - diferentemente do ser dos fatos naturais - nos é dada ou se nos apresenta. A 'existência' de uma norma positiva, a sua vigência, é diferente da existência do ato de vontade de que ela é o sentido objetivo. A norma pode valer (ser vigente) quando o ato de vontade de que ela constitui o sentido já não existe. Sim, ela só entra mesmo em vigor depois de o ato de vontade, 
Conceito distinto, porque figura na órbita do ser, ou seja, no mundo fático, é o de eficácia, o qual diz respeito à efetiva aplicação e observância da norma jurídica, sendo que a eficácia pressupõe a vigência, contudo a vigência não demanda a eficácia, a não ser em evidente grau mínimo ${ }^{15}$.

Um ponto relevante na teoria pura diz respeito ao domínio de validade material da norma jurídica ${ }^{16}$, na medida em que se circunscreve a regular tão somente a conduta humana, sendo que os demais fatos que não derivam diretamente da ação ou inação do homem somente podem ser alvo do conteúdo objetivo de normas se estiverem em conexão com a conduta humana em condição ou efeito dela ${ }^{17}$, o que distingue o pensamento de $\operatorname{KELSEN}^{18}$, mas não o afasta da posição segundo a qual os fatos jurídicos

cujo sentido ela constitui, ter deixado de existir. $\mathrm{O}$ individuo que, com o seu ato intencional dirigido à conduta de outrem, criou uma norma jurídica, não precisa continuar a querer essa conduta para que a norma que constitui o sentido do seu ato valha (seja vigente). (...)". Negritouse.

15 H. KELSEN, Reine Rechtslehre, 1960, trad. port. de João Baptista Machado, Teoria Pura do Direito, 6a ed., São Paulo, Martins Fontes, 1998, pp. 11 e 12:

"Como a vigência da norma pertence à ordem do dever-ser, e não à ordem do ser, deve também distinguir-se a vigência da norma da sua eficácia, isto é, do fato real de ela ser efetivamente aplicada e observada, da circunstância de uma conduta humana conforme à norma se verificar na ordem dos fatos. Dizer que uma norma vale (é vigente) traduz algo diferente do que se diz quando se afirma que ela é efetivamente aplicada e respeitada, se bem que entre vigência e eficácia possa existir uma certa conexão. Uma norma jurídica é considerada como objetivamente válida apenas quando a conduta humana que ela regula lhe corresponde efetivamente, pelo menos numa certa medida. Uma norma que nunca e em parte alguma é aplicada e respeitada, isto é, uma norma que - como costuma dizer-se - não é eficaz em uma certa medida, não será considerada como norma válida (vigente). Um mínimo de eficácia (como sói dizer-se) é a condição da sua vigência. (...) Vigência e eficácia de uma norma jurídica também não coincidem cronologicamente. Uma norma jurídica entra em vigor antes ainda de se tornar eficaz, isto é, antes de ser seguida e aplicada. (...)". Negritou-se. H. KELSEN, Reine Rechtslehre, 1960, trad. port. de João Baptista Machado, Teoria Pura do Direito, $6^{\text {a }}$ ed., São Paulo, Martins Fontes, 1998, pp. 15 e 16:

"(...) Pode falar-se ainda de um domínio material de validade tendo em conta os diversos aspectos da conduta humana que são normados: aspecto econômico, religioso, político, etc. (...)".

H. Kelsen, Reine Rechtslehre, 1960, trad. port. de João Baptista Machado, Teoria Pura do Direito, $6^{\text {a }}$ ed., São Paulo, Martins Fontes, 1998, p. 16:

"(...) $\mathrm{O}$ que as normas de um ordenamento regulam é sempre uma conduta humana, pois apenas a conduta humana é regulável através das normas. Os outros fatos que não são conduta humana somente podem constituir conteúdo de normas quando estejam em conexão com uma conduta humana - ou, como já notamos, apenas enquanto condição ou efeito de uma conduta humana. (...)". Negritou-se.

18 H. KELSEN, Reine Rechtslehre, 1960, trad. port. de João Baptista Machado, Teoria Pura do Direito, 6a ed., São Paulo, Martins Fontes, 1998, p. 35:

"(...) A autoridade jurídica prescreve uma determinada conduta humana apenas porque - com razão ou sem ela - a considera valiosa para a comunidade jurídica dos indivíduos. Esta referência à comunidade jurídica é também decisiva, em última análise, para a regulamentação jurídica da conduta de uma pessoa determinada. Não é apenas - e talvez não seja tanto - o interesse do credor concreto aquilo que é protegido pela norma jurídica que vincula o devedor ao pagamento: é antes o interesse da comunidade - apreciado pela autoridade jurídica - na manutenção de um determinado sistema econômico". 
são aqueles acontecimentos do mundo do ser derivados da conduta humana ou de eventos da natureza, mas estes quando capazes de interferir na órbita do direito, porque consoantes ao conteúdo objetivo de uma norma jurídica que lhes prescreva consequências para a comunidade jurídica.

Necessariamente atrelado ao esquema de interpretação conferido às normas jurídicas, figura o conceito de sanção, o que caracteriza o ordenamento jurídico como ordem coativa $^{19}$, significando que à comunidade jurídica é atribuído o poder de impingir àquele agente cuja conduta indesejável prescrita foi verificada ou àquele agente acometido de um evento natural alheio ao seu interesse subjetivo, um mal contra a sua vontade, podendo empregar nesse sentido até mesmo a força física. E nesse ponto, o direito se distancia das demais ordens sociais $^{20}$, na medida que estas também prescrevem condutas de dever ser, mas não dispõem do poder de impor males àqueles agentes que incorrem na conduta oposta à prescrita ${ }^{21}$. Essa assertiva também deságua na

H. KELSEN, Reine Rechtslehre, 1960, trad. port. de João Baptista Machado, Teoria Pura do Direito, $6^{a}$ ed., São Paulo, Martins Fontes, 1998, pp. 35 e 36:

"Uma outra característica comum às ordens sociais a que chamamos Direito é que elas são ordens coativas, no sentido de que reagem contra as situações consideradas indesejáveis, por serem socialmente perniciosas - particularmente contra condutas humanas indesejáveis - com um ato de coação, isto é, com um mal - como a privação da vida, da saúde, da liberdade, de bens econômicos e outros -, um mal que é aplicado ao destinatário mesmo contra sua vontade, se necessário empregando até a força física - coativamente, portanto. Dizer-se que, com o ato coativo que funciona como sanção, se aplica um mal ao destinatário, significa que este ato é normalmente recebido pelo destinatário como um mal. (...)". Com outras palavras, Goffredo TELLES JUNIOR define a norma jurídica como imperativo autorizante, visto que permite que se exija dos seus violadores a observância do seu imperativo, a reparação dos males causados ou a imposição de penas.

"Jurídicas são as normas que autorizam a reação correspondente à ação violadora da norma. Essa reação é a que se acha devidamente autorizada por norma jurídica, e tanto pode ser o ato de 'fazer justiça com as próprias mãos' (ato este permitido pelo Direito, em casos estritos: Código Penal, arts. 23 e 24), como pode ser o pedido formal, feito em juízo.

Somente são jurídicas as normas aptas a ser invocadas como fundamento válido de uma pretensão submetida ao Poder incumbido de 'distribuir justiça' numa sociedade. Isto significa que somente são jurídicas as normas que autorizam alguém a submeter sua pretensão ao referido Poder" ( $A$ Norma Jurídica, in Estudos, São Paulo, Juarez de Oliveira, 2005, pp. 11 e 12).

Distancia-se, contudo, da Teoria Pura do Direito na medida em que afirma que a norma jurídica não é atributiva, porque a faculdade de exercer coação é imanente à natureza humana e a norma tão somente autoriza o exercício dessa mesma faculdade imanente.

"Depreende-se, do que se acaba de demonstrar, que a norma jurídica não atribui faculdade nenhuma. O que lhe é próprio é exprimir uma autorização dada pela sociedade. A norma jurídica é o instrumento pelo qual o lesado, para os fins legais, fica autorizado a exercer sua faculdade de exigir e de coagir.

A norma jurídica não é atributiva. Ela é autorizante" (A Norma Jurídica, in Estudos, São Paulo, Juarez de Oliveira, 2005, p. 16). Direito, 6a ed., São Paulo, Martins Fontes, 1998, p. 37:

"Como ordem coativa, o Direito distingue-se de outras ordens sociais. O momento coação, isto é, a circunstância de que o ato estatuído pela ordem como consequiência de uma situação de fato 
conclusão de que diferente do que normalmente assegura a communis opinio, a conduta humana positiva ou negativa ou até mesmo o evento que dá azo à imputação do ato coercitivo, particularmente da sanção, não se caracterizam como contrários ao direito ou fora da órbita do direito ${ }^{22}$, mas, pelo contrário, são seus pressupostos, ou seja, são as condutas nominadas ilícitos ou delitos que dão azo à aplicação do direito, porque na medida em que se verificam, devem ser executados os atos coativos fixados pela norma jurídica pertinente.

O sistema se fecha, na visão de KELSEN, com a chamada norma fundamental ${ }^{23}$, que é pressuposta e prescreve em seu conteúdo que uma determinada comunidade jurídica deve se comportar conforme as normas postas sob determinados sentidos objetivos e que são capazes de impor aos indivíduos daquele grupo determinado atos coercitivos caso incorram nas condutas opostas àquelas prescritas como dever ser $^{24}$.

considerada socialmente prejudicial deve ser executado mesmo contra a vontade da pessoa atingida e - em caso de resistência - mediante o emprego da força física, é o critério decisivo". Caio Mário da SILva PereIRA, Instituições de Direito Civil - Introdução ao Direito Civil - Teoria Geral do Direito Civil, vol. I, $23^{\mathrm{a}}$ ed. atual. por Maria Celina Bodin de Moraes, Rio de Janeiro, Forense, 2010, p. 4:

"O fenômeno jurídico é perceptível, e mais patentemente ainda a idéia de direito em contraposição à sua negação: diante da ofensa, da contrariedade ou da distorção, aparece viva a idéia de direito. Não seria, porém, de todo razoável que o jurista se julgasse habilitado a conceituar o direito apenas em face da idéia contrária, como se dissesse que a idéia de ser fosse tão-somente a antinomia do não-ser".

23 H. KELSEN, Reine Rechtslehre, 1934, trad. port. de J. Cretella Jr. e Agnes Cretella, Teoria Pura do Direito - Introdução à Problemática Científica do Direito - Versão Condensada pelo Próprio Autor, $4^{\mathrm{a}}$ ed., São Paulo, RT, 2006, p. 96:

"A norma fundamental de um ordenamento jurídico positivo não é, em compensação, nada mais que uma regra fundamental, conforme a qual são produzidas as normas do ordenamento jurídico, a criação da estabilidade fundamental da produção jurídica. Ela é o ponto de partida de um procedimento; possui um caráter eminentemente dinâmico-formal. Desta norma fundamental não se pode deduzir logicamente as normas do sistema jurídico. Devem ser produzidas por um ato institucional especial - que não é ato racional - mas volitivo. A instituição de normas jurídicas se desenvolve de diversas maneiras: por meio de costumes ou pelo processo legislativo, enquanto se tratar de normas gerais; por atos de jurisdição e por atos negociais nas normas individuais".

24 H. KELSEN, Reine Rechtslehre, 1960, trad. port. de João Baptista Machado, Teoria Pura do Direito, 6a ed., São Paulo, Martins Fontes, 1998, p. 56:

"Se se concebe o Direito como uma ordem de coerção, a fórmula com a qual traduzimos a norma fundamental de uma ordem jurídica estadual significa: a coação de um indivíduo por outro deve ser praticada pela forma e sob os pressupostos fixados pela primeira Constituição histórica. A norma fundamental delega na primeira Constituição histórica a determinação do processo pelo qual se devem estabelecer as normas estatuidoras de atos de coação. Uma norma, para ser interpretada objetivamente como norma jurídica, tem de ser o sentido subjetivo de um ato posto por este processo - pelo processo conforme à norma fundamental - e tem de estatuir um ato de coação ou estar em essencial ligação com uma norma que o estatua. Com a norma fundamental, portanto, pressupõe-se a definição nela contida do Direito como norma coercitiva. A definição do Direito pressuposta na norma fundamental tem como conseqüência que apenas se deve considerar como juridicamente prescrita - ou, o que é o mesmo, como conteúdo de um dever jurídico - uma certa conduta, quando a conduta oposta seja normada como pressuposto de um ato coercitivo que é dirigido contra os indivíduos que por tal forma se conduzam (ou 
Primordial, assim, para o sistema é a figura da sanção, que deve ser aplicada caso verificada a conduta que lhe dá azo, permitindo ainda dizer que supérflua é a norma que prescreve determinado comportamento, mas precípua é aquela que prescreve a conduta oposta, a qual uma vez verificada ocasiona a aplicação da sanção ${ }^{25}$.

Definem-se, assim, o ilícito ou o delito tão somente porque a ordem jurídica imputou a uma determinada conduta humana (ação ou omissão) a incidência de uma sanção e não porque essa mesma conduta tenha per se ou carregue de forma imanente um caráter ilícito ou delituoso ${ }^{26}$. Conclui-se com maior evidência que o ilícito ou delito - diferente do que tradicionalmente se propaga - não representa uma negação do direito, mas o seu pressuposto ou condição, visto que verificados desencadeiam a aplicação da

contra os seus familiares). Deve notar-se, no entanto, que o próprio ato de coação não precisa ser prescrito com este sentido, que a sua decretação e a sua execução podem ser apenas autorizadas". Negritou-se.

H. KELSEN, Reine Rechtslehre, 1960, trad. port. de João Baptista Machado, Teoria Pura do Direito, 6a ed., São Paulo, Martins Fontes, 1998, pp. 60 e 61:

"Já num outro contexto fizemos notar que, quando uma norma prescreve uma determinada conduta e uma segunda norma estatui uma sanção para a hipótese da não-observância da primeira, estas duas normas estão essencialmente interligadas. Isto vale particularmente para a hipótese em que um ordenamento normativo - como o ordenamento jurídico - prescreve uma determinada conduta pelo fato de ligar à conduta oposta um ato coercitivo a título de sanção, de tal forma que uma conduta somente se pode considerar como prescrita, nos termos desse ordenamento - e, portanto, no caso do ordenamento jurídico, como juridicamente prescrita - se a conduta oposta é pressuposto de uma sanção. Se uma ordem jurídica ou uma lei feita pelo parlamento contém uma norma que prescreve uma determinada conduta e uma outra norma que liga à não-observância da primeira uma sanção, aquela primeira norma não é uma norma autônoma, mas está essencialmente ligada à segunda; ela apenas estabelece - negativamente - o pressuposto a que a segunda liga a sanção. $\mathbf{E}$, quando a segunda norma determina positivamente o pressuposto a que liga a sanção, a primeira torna-se supérflua do ponto de vista da técnica legislativa. (...)". Negritou-se.

H. KELSEN, Reine Rechtslehre, 1960, trad. port. de João Baptista Machado, Teoria Pura do Direito, $6^{\text {a }}$ ed., São Paulo, Martins Fontes, 1998, pp. 124 e 125:

"A relação entre ilícito e conseqüência do ilícito não consiste, assim - como pressupõe a jurisprudência tradicional -, em a uma ação ou omissão, pelo fato de representar um ilícito ou delito, ser ligado um ato de coação como conseqüência do ilícito, mas em uma ação ou omissão ser um ilícito ou delito por lhe ser ligado um ato de coação como sua consequiência. Não é uma qualquer qualidade imanente e também não é qualquer relação com uma norma metajurídica, natural ou divina, isto é, qualquer ligação com um mundo transcendente ao Direito positivo, que faz com que uma determinada conduta humana tenha de valer como ilícito ou delito - mas única e exclusivamente o fato de ela ser tornada, pela ordem jurídica positiva, pressuposto de um ato de coerção, isto é, de uma sanção.

(...) Do ponto de vista de uma teoria do Direito positivo não há qualquer fato que, em si e por si, isto é, sem ter consideração a respectiva consequiência estatuída pela ordem jurídica, seja um ilícito ou delito. Não há mala in se, mas apenas mala prohibita. Isto é, de resto, apenas a conseqüência do princípio geral reconhecido no direito penal, nullum crimen sine lege, nulla poena sine lege; e este princípio, que vale não só para o direito penal, não só para os delitos criminais, como também para todos os delitos, não só em relação às penas mas também em relação a todas as sanções, é tãosomente a conseqüência do positivismo jurídico. Um e o mesmo fato é, segundo uma ordem jurídica, um ilícito ou delito, por esta lhe ligar a uma sanção, e não o é segundo uma outra que não prevê tal conseqüência". Negritou-se. 
sanção e caso não verificados, porque a conduta humana do agente lhe foi oposta, evitam ou afastam a incidência da mesma sanção prescrita pelo ordenamento jurídico ${ }^{27}$.

Nesse sentido, KELSEN fulmina a ideia recorrente de que sobre o direito posto existe uma órbita de preceitos ideal, universal e eterna que lhe inspira, ditando ao ordenamento jurídico valores - até mesmo porque os valores não são absolutos e em sua relatividade variam no tempo e no espaço. Higieniza o direito da possibilidade de se subordinar a regras e preceitos que lhes sejam estranhos e ostentem caráter nitidamente ideológico, para impor ao ordenamento a realização de um equívoco e polissêmico ideal de justiça ${ }^{28}$.

Destarte, o conceito de norma jurídica se equipara ao de dever jurídico, porque sendo este a conduta humana conforme a prescrição da ordem jurídica, é também o conteúdo da norma posta suficiente a afastar a incidência do ato de coação (sanção). Na hipótese de cumprimento do dever jurídico, verifica-se a observância da norma, enquanto na situação em que se tem a conduta humana oposta ao dever jurídico,

H. KELSEN, Reine Rechtslehre, 1960, trad. port. de João Baptista Machado, Teoria Pura do Direito, $6^{\text {a }}$ ed., São Paulo, Martins Fontes, 1998, p. 127:

"Se uma ordem normativa prescreve uma determinada conduta apenas pelo fato de ligar uma sanção à conduta oposta, o essencial da situação de fato é perfeitamente descrito através de um juízo hipotético que afirme que, se existe uma determinada conduta, deve ser efetivado um determinado ato de coação. Nesta proposição, o ilícito aparece como um pressuposto (condição) e não como uma negação do Direito; e, então, mostra-se que o ilícito não é um fato que esteja fora do Direito e contra o Direito, mas é um fato que está dentro do Direito e é por este determinado, que o Direito, pela sua própria natureza, se refere precisa e particularmente a ele. Como tudo o mais, também o ilícito (não-Direito) juridicamente apenas pode ser concebido como Direito. Quando se fala de conduta 'contrária'-ao-Direito, o elemento condicionante é o ato de coação; quando se fala de conduta 'conforme'-ao-Direito, significa-se a conduta oposta, a conduta que evita o ato de coação".

28 Caio Mário da SILva PereIRA, Instituições de Direito Civil - Introdução ao Direito Civil - Teoria Geral do Direito Civil, vol. I, $23^{\mathrm{a}}$ ed. atual. por Maria Celina Bodin de Moraes, Rio de Janeiro, Forense, 2010, p. 6:

"Fixando-se, porém, o jurista na órbita do direito em si, é forçado a reconhecer que acima do direito positivo, e sobre este influindo no propósito de realizar o ideal de justiça, ditado por uma concepção de superlegalidade, o direito natural sobrepaira à norma legislativa, e, com este sentido, é universal e é eterno, integrando a norrnação ética da vida humana, em todos os tempos e em todos os lugares. Se alguma vez, sob o império de forças antijurídicas, declina o sentimento do justo, a humanidade supera a crise e retoma o seu caminho, procurando sempre o ideal da justiça, que se radica indefectivelmente na consciência humana.

Costuma-se dizer que o direito positivo se opõe ao direito natural, aquele representando o regime de vida social corrente, este o conjunto de princípios ideais preexistentes e dominantes. Enquanto o direito positivo é nacional e contingente, o direito natural é universal e eterno. Não se poderá, entretanto e em verdade, falar em contraposição ou antinomia, pois que, se um é a fonte de inspiração do outro, não exprimem idéias antagônicas, mas, ao revés, tendem a uma convergência ideológica, ou, ao menos, devem procurá-la, o direito positivo amparando-se na sujeição ao direito natural para que a regra realize o ideal, e o direito natural inspirando o direito positivo para que este se aproxime da perfeição". 
verifica-se a aplicação da mesma norma jurídica por meio da imputação do ato coercitivo prescrito. Importa ressaltar que ambas as situações (condutas) estão conforme o direito e denotam a sua eficácia ${ }^{29}$.

Essa construção teórica afasta em definitivo a concepção do direito natural como parâmetro para a ordem jurídica pressupondo elementos estranhos ao ordenamento a lhe inspirar e concebendo como normas aquelas regras harmônicas com o direito ideal e eterno derivado da consciência e da razão humana ${ }^{30}$. Direito, $6^{a}$ ed., São Paulo, Martins Fontes, 1998, p. 130:

"Com isto fica determinado o conceito de dever jurídico. Este encontra-se numa relação essencial com a sanção. Juridicamente obrigado está o indivíduo que, através da sua conduta, pode cometer o ilícito, isto é, o delito, e, assim, pode provocar a sanção, a conseqüência do ilícito - o delinqüente potencial; ou o que pode evitar a sanção pela conduta oposta. No primeiro caso, fala-se da violação do dever, no segundo, em cumprimento do dever. $O$ indivíduo que cumpre o dever que lhe é imposto por uma norma jurídica, observa a norma jurídica; o indivíduo que, em caso de violação do Direito, efetiva a sanção estatuída na norma jurídica, aplica a norma. Tanto a observância da norma jurídica como a sua aplicação representam uma conduta conforme a norma. Se, por eficácia de uma ordem jurídica, se entende o fato de os indivíduos - cuja conduta ela regula enquanto liga a uma conduta por ela determinada um ato coercitivo, igualmente por ela determinado, a título de sanção - se conduzirem em conformidade com as suas normas, então essa eficácia manifesta-se tanto na efetiva observância das normas jurídicas, isto é, no cumprimento dos deveres jurídicos por elas estatuídos, como na aplicação das normas jurídicas, isto é, na efetivação das sanções por elas estatuídas". Negritou-se. Geral do Direito Civil, vol. I, 23 ${ }^{\mathrm{a}}$ ed. atualizada por Maria Celina Bodin de Moraes, Rio de Janeiro, Forense, 2010, p. 7:

"Hugo Grócio, no século XVI, sustentando que em oposição ao direito positivo, imperfeito e transitório, há um direito ideal e eterno, impregnado na consciência e gerado pela razão humana, criou a chamada escola de direito natural, que se estendeu por toda a Europa, conquistando a todos os filósofos e pensadores, para a qual o direito natural é o paradigma da lei mutável e humana e, por isto, as leis não têm base na vontade do legislador, que é apenas o intérprete ou o veículo da lei natural".

Como se denota, Caio Mário da Silva PereirA, com inequívoco desacerto, rejeita a posição de KELSEN insistindo na opinião segundo a qual o direito positivo deve ser sempre balizado por "ideais de justiça" de inspiração elevada.

"Vê-se, então, que em mais de dois mil anos de civilização ocidental sempre se admitiu e ainda se afirma que nenhum sistema de direito positivo pode libertar-se das inspirações mais abstratas e mais elevadas. Não é possível situar o fenômeno ius no campo da pura elaboração legislativa, sendo forçoso reconhecer a existência de uma ordem superior e dominante, de uma justiça absoluta e ideal, que o direito positivo realiza dentro do contingente da norma legislada, e sem o qual esta dificilmente se distinguiria do capricho estatal. Se se indagar por que a formulação da regra de conduta segue um determinado rumo, e não outro; se se investigar a razão de os sistemas jurídicos de nações diferentes coincidirem na obtenção de finalidades análogas e às mais das vezes idênticas; se se pesquisar o motivo de não se apresentar o direito positivo como a expressão caprichosa e desenfreada do legislador eventual, encontrar-se-á como uma constante irrefugível a contenção nos limites da realização de padrões abstratos e não formulados. Cumpre, entretanto, assinalar, como faz Enneccerus, que no caso de insubordinação do direito positivo ao direito ideal ou à justiça absoluta, caberá ao legislador corrigir a falha pela derrogação da lei má, mas não ao juiz recusar-lhe a aplicação em nome da justiça ideal. $\mathrm{O}$ anseio superior pela realização do justo abstrato deve sobrepairar ao ordenamento positivo, pois que, no dizer de Del Vecchio, é uma exigência fundamental da consciência humana conceber a idéia do justo como absoluta e admitir 
Na mesma linha é o pensamento no Brasil de SAN TIAGo DANTAS, para quem a norma jurídica deve ser analisada sobre três aspectos: estrutura externa, estrutura interna e conteúdo ${ }^{31}$. A estrutura externa é o invólucro por meio do qual se apresentam as normas jurídicas, sendo o mais comum deles a lei, porém não se podendo descurar do decretos e regulamentos, bem como do costume e da jurisprudência ${ }^{32}$. A estrutura interna se decompõe, para esse autor nacional, em comando e sanção, definido o primeiro como sendo o que deve o indivíduo fazer ou como se deve comportar e a segunda como o mal a que está ameaçado o indivíduo refratário ao comando ${ }^{33}$. E o

um critério absoluto e ideal da justiça e do direito, independente do fato de sua sanção positiva. O direito natural é a expressão destes critérios de justo absoluto e de direito ideal" (Op. cit., pp. 7 e 8).

31 Francisco Clementino de SAN TIAgo DanTAs, Programa de Direito Civil - Aulas proferidas na Faculdade Nacional de Direito [1942-1945] - Parte Geral, 2 ed., Rio de Janeiro, Rio, 1979, p. 58:

"Pode-se considerá-la sob três aspectos; quanto à sua estrutura externa, quanto à sua estrutura interna e, finalmente, quanto ao seu conteúdo. Se quiser-se, então, a coisa de uma maneira mais lógica, a norma jurídica pode ser estudada como forma e como matéria. Como forma se estuda a forma interna; como matéria, é o estudo do seu conjunto. Mas não se vai adotar esta terminologia tão escolástica, e sim estrutura interna, estrutura externa, conteúdo e norma".

32 Francisco Clementino de SAN Tiago Dantas, Programa de Direito Civil - Aulas proferidas na Faculdade Nacional de Direito [1942-1945] - Parte Geral, 2 ed., Rio de Janeiro, Rio, 1979, p. 58:

"Como estrutura externa a norma quase sempre aparece como lei. A lei é o tipo da estrutura externa, mas ainda se tem outros, vamos dizer, os regulamentos, os decretos, as várias formas administrativas pelas quais se anunciam normas jurídicas, são tipos que pertencem ao domínio da estrutura externa da norma, ainda se pode apontar o costume. Muitas vezes a norma jurídica se apresenta num invólucro que é o próprio costume, a própria tradição oral ou escrita que se transmite num determinado lugar. Outras vezes o invólucro da norma jurídica é a jurisprudência, isto é, os julgados dos tribunais, que repete uma mesma solução e tornando esta vinculativa para outras decisões posteriores".

33 Francisco Clementino de SAn Tiago Dantas, Programa de Direito Civil - Aulas proferidas na Faculdade Nacional de Direito [1942-1945] - Parte Geral, 2a ed., Rio de Janeiro, Rio, 1979, p. 59:

"Agora, à estrutura interna o que pertence? Quando se considera uma norma jurídica qualquer e se examina a sua estrutura interna, nela se descobrem, sempre dois elementos: um é o comando; outro é a sanção - a sanção e o comando.

O comando é aquilo que se deve fazer, a sanção é aquilo que acontece se assim não se fizesse. Já se sabe que é uma característica fundamental do direito a coercibilidade, de maneira que se pode afirmar: não há norma jurídica sem sanção. A sanção é o mal de que se está ameaçado no caso de não se obedecer ao comando. Os dois elementos são, por conseguinte, inseparáveis.

Não se pode compreender comando sem sanção porque este comando não seria jurídico e também não se pode conceber sanção sem comando, pois que este é a ameaça que nos é dirigida no caso de não se obedecer a um certo preceito de lei. Então, do ponto de vista da sua estrutura íntima a norma se analisa nestes dois elementos: comando, sanção".

Na mesma direção doutrinária aponta o magistério de M. A. COELHO DA RoCHA, quem lecionando ainda sob a vigência das vetustas Ordenações Filipinas (1844) também decompunha a essência da lei em parte dispositiva e sanção, não deixando de exclarecer, por evidente influência da teoria do direito natural então reinante que a conduta conforme a norma jurídica (lei) seria justa e a aposto seria qualificada como injusta.

M. A. Coelho DA RochA, Instituições de Direito Civil, Tomo I, São Paulo, Saraiva, 1984, p. 3:

"\$2. Lei é a regra estabelecida para as ações dos homens por uma autoridade, a quem se deve obedecer. A ação conforme com esta regra diz-se justa; a que se lhe opõe, injusta. É da essência da 
conteúdo da norma jurídica pode ostentar vários matizes, porém a sua investigação afasta-se do âmbito de interesse da ciência jurídica ${ }^{34}$.

Importante, todavia, é o conceito de dever jurídico, como exposto na Teoria Pura do Direito, que ganha relevância na medida em que tradicionalmente é contraposto ao de direito subjetivo, significando este o poder conferido ao indivíduo destinatário do dever de exigir ou reclamar a conduta a que outro indivíduo está obrigado pelo ordenamento jurídico. KELSEN, contudo, demonstra que a apontada distinção, embora possa até ser útil para representar esquematicamente as situações jurídicas, é supérflua para a sua descrição científica. Explica que na contraposição entre dever jurídico e direito subjetivo, por meio da qual o segundo conceito traduz o "direito" ou "pretensão" do indivíduo perante o qual outro indivíduo está obrigado a uma conduta positiva ou negativa ou a um dever de tolerância, na realidade subsume-se tão somente ao conceito do dever jurídico do indivíduo obrigado, quem por sua conduta pode observar a prescrição normativa ou optar pela conduta oposta igualmente prescrita e se expor à imputação de uma sanção. O indivíduo destinatário do dever jurídico funciona como mero objeto da conduta prescrita, porque a sua dita "pretensão" é mero reflexo do dever a que o outro indivíduo está obrigado pela ordem normativa a observar $^{35}$.

lei: $1^{\circ}$ ) a parte dispositiva, ou a expressão da vontade do legislador; $2^{\circ}$ ) a sanção, isto é, a pena imposta ao transgressor. Quando em alguma lei civil a sanção não é explícita, sempre se subentende ou a nulidade do ato, ou a ação judicial, que compete ao interessado na observância da lei contra o transgressor".

Francisco Clementino de SAN Tiago Dantas, Programa de Direito Civil - Aulas proferidas na Faculdade Nacional de Direito [1942-1945] - Parte Geral, 2a ed., Rio de Janeiro, Rio, 1979, p. 59:

"E quanto ao conteúdo material? O conteúdo material da norma é geralmente uma regra econômica, ética, política, religiosa ou simplesmente moral, que o legislador adotou, que ele incorporou na norma e que poderia mudar sem que a norma deixasse por isso de ser, norma, de ser norma jurídica".

35 H. KELSEN, Reine Rechtslehre, 1960, trad. port. de João Baptista Machado, Teoria Pura do Direito, 6a ed., São Paulo, Martins Fontes, 1998, pp. 142 e 143:

"Esta situação, designada como 'direito' ou 'pretensão' de um indivíduo, não é porém, outra coisa senão o dever do outro ou dos outros. Se, neste caso, se fala de um direito subjetivo ou de uma pretensão de um indivíduo, como se este direito ou esta pretensão fosse algo de diverso do dever do outro (ou dos outros), cria-se a aparência de duas situações juridicamente relevantes onde só uma existe. A situação em questão é esgotantemente descrita com o dever jurídico do indivíduo (ou dos indivíduos) de se conduzir por determinada maneira em face de um outro indivíduo. Dizer que um indivíduo é obrigado a uma determinada conduta significa que, no caso da conduta oposta, se deve verificar uma sanção; o seu dever é a norma que prescreve esta conduta enquanto liga uma sanção à conduta oposta. Quando um indivíduo é obrigado em face de outro a uma determinada prestação, é a prestação a receber pelo outro que forma o conteúdo do dever; apenas se 
Sendo dessa forma o conceito de direito equivalente ao de dever jurídico conduta humana prescrita pelo ordenamento jurídico - fulmina-se a tradicional dicotomia fixada entre direito objetivo e direito subjetivo, uma vez que o segundo é mero reflexo do primeiro e anódino para ciência do direito, além de encontrar suas raízes também no direito natural, que insistia em asseverar a preexistência de direitos inatos ao homem ${ }^{36}$ e anteriores a qualquer norma posta ${ }^{37}$.

Em outras palavras, KELSEN nega a existência do direito subjetivo como categoria apartada da norma objetiva posta pela comunidade jurídica, assegurando que se trata tão somente de corolário do dever jurídico imposto, cuja inobservância dará azo à imputação do ato coercitivo prescrito $^{38}$. Essa posição, porém, não é agasalhada de

pode prestar a outrem algo que esse outrem receba. E, quando um indivíduo está obrigado em face de outrem a suportar uma determinada conduta deste, é a tolerância desta mesma conduta que constitui o conteúdo do dever. Quer dizer: a conduta do indivíduo em face do qual o dever existe, correlativa da conduta devida, está já conotada na conduta que forma o conteúdo do dever. Se se designa a relação do indivíduo, em face do qual uma determinada conduta é devida, com o indivíduo obrigado a essa conduta como 'direito', este direito é apenas um reflexo daquele dever.

A propósito, importa notar que 'sujeito' nesta relação é apenas o obrigado, isto é, aquele indivíduo que pela sua conduta pode violar ou cumprir o dever. $O$ indivíduo que tem direito, isto é, aquele em face do qual esta conduta há de ter lugar, é apenas objeto da conduta que, como correspondente à conduta devida, está já conotada nesta. Este conceito de um direito subjetivo que apenas é o simples reflexo de um dever jurídico, isto é, o conceito de um direito reflexo, pode, como conceito auxiliar, facilitar a representação da situação jurídica. É, no entanto, supérfluo do ponto de vista de uma descrição cientificamente exata da situação jurídica. (...)". Negritou-se.

Definindo o direito subjetivo como sendo "permissões dadas por meio de normas jurídicas", Goffredo TELLES JUNIOR assevera tratar-se de direitos imanentes à natureza humana, para os quais a ordem jurídica tão somente assegura ao homem a possibilidade usar dessa faculdade que já lhe é intrínseca.

O Direito Subjetivo, in Estudos, São Paulo, Juarez de Oliveira, 2005, p. 121:

"O Direito Subjetivo é subjetivo porque as permissões, que o constituem, são próprias das pessoas que as possuem; são permissões que lhes pertencem, podendo ser usadas, ou não usadas, por elas; permissões, portanto, que a elas se sujeitam, e que, de certa maneira, estão dentro delas.

(...)

Os Direitos Subjetivos não se acham fora das pessoas que os detém; não se colocam diante delas. Pelo contrário, as permissões constitutivas de tais Direitos, após serem concedidas e assumidas, se incorporam a seus titulares, como qualidades próprias deles".

H. KELSEN, Reine Rechtslehre, 1960, trad. port. de João Baptista Machado, Teoria Pura do Direito, $6^{\text {a }}$ ed., São Paulo, Martins Fontes, 1998, pp. 144 e 145:

"A concepção tradicional de que o direito é um objeto do conhecimento jurídico diferente do dever, de que àquele caberia mesmo a prioridade em relação a este, é sem dúvida devida à doutrina do Direito natural. Esta parte da suposição de direitos naturais, de direitos inatos ao homem, que existem antes de toda e qualquer ordem jurídica positiva. (...). Se se afasta a hipótese dos direitos naturais e se reconhecem apenas os direitos estatuídos por uma ordem jurídica positiva, então verifica-se que um direito subjetivo, no sentido aqui considerado, pressupõe um correspondente dever jurídico, é mesmo este dever jurídico".

38 Caio Mário da SILva PereIRA, Instituições de Direito Civil - Introdução ao Direito Civil - Teoria Geral do Direito Civil, vol. I, 23 $3^{\text {a }}$ ed. atualizada por Maria Celina Bodin de Moraes, Rio de Janeiro, Forense, 2010, p. 26: 
forma unânime, prevalecendo na doutrina a insistência no tocante à distinção de $\operatorname{conceitos}^{39}$ e à necessária correspondência entre o dever jurídico e o poder jurídico, significando o segundo exatamente a faculdade veiculada pelo direito subjetivo. Sob essa óptica, estabelece-se na relação jurídica dois pólos, um positivo - figurado pelo sujeito ativo a quem compete a faculdade de exigir a observância da prescrição normativa - e um negativo - este figurado pelo sujeito passivo titular do dever jurídico e alvo do comando normativo ou da reclamação do sujeito ativo ${ }^{40}$.

"Kelsen, normativista, nega o direito subjetivo, partindo de que o direito se confunde com o Estado, no sentido de que este é um sistema de normas, impostas aos indivíduos, e em conseqüência não poderá haver prerrogativas individuais em relação ao Estado. Se este determina uma dada conduta individual, agirá contra o ofensor da norma no propósito de constrangê-lo à observância, sem que o fato de alguém reclamar a atitude estatal de imposição se traduza na existência de uma faculdade reconhecida. Em toda parte do mundo jurídico, o que existe é a norma, seja a norma geral, criada pelo Estado, seja a norma individual, criada pela declaração de vontade, por delegação dele. A norma jurídica, que é a essência do direito, pode ser encarada num sentido objetivo, ou pode ser vista em sentido subjetivo, nas relações individuais, mas, em qualquer caso, a teoria do direito enxerga sempre a norma".

Goffredo Telles Junior, O Direito Subjetivo, in Estudos, São Paulo, Juarez de Oliveira, 2005, pp. 138 e 139:

"Estreitas são as relações entre o Direito Subjetivo e o Direito Objetivo. Por mais distintos que sejam os dois Direitos, não pode um existir sem o outro.

Efetivamente, não se compreende o Direito Objetivo, a não ser em razão do Direito Subjetivo. Por que? Porque o Direito Objetivo existe para indicar os movimentos humanos que, em sociedade, podem ser oficialmente exigidos e proibidos. Em outras palavras: o Direito Objetivo existe para revelar, primeiro, a permissão de exigir a prática de certos atos; segundo a permissão de praticar os atos não proibidos. Ora, tais permissões, como se viu, constituem, exatamente, os Direitos Subjetivos. Logo, sem Direito Subjetivo, o Direito Objetivo não teria razão de ser.

E não há Direito Subjetivo sem Direito Objetivo. Por que? Porque as permissões, de que os Direitos Subjetivos são constituídos, são dadas por meio do Direito Objetivo.

Não há, finalmente, Direito Subjetivo contra Direito Objetivo. Por sua natureza, os Direitos Subjetivos se acham sempre na dependência do Direito Objetivo. É evidente que as permissões decorrem do ato de permitir, e a este se subordinam. Seria um contra-senso que o Direito Objetivo fosse a expressão de permissões para a prática de ações contrárias aos mandamentos manifestados pelo próprio Direito Objetivo". Geral do Direito Civil, vol. I, 23 ${ }^{\mathrm{a}}$ ed. atualizada por Maria Celina Bodin de Moraes, Rio de Janeiro, Forense, 2010, p. 36:

"Correlata à idéia do direito subjetivo define-se ainda a do dever jurídico. A concepção do poder jurídico não está completa sem a correspondência de um dever. Se o direito subjetivo traduz um vínculo, é indispensável a noção de um ente abstratamente ligado àquele que tem o poder de realização do direito. Direito e dever se completam, um dependente do outro. Havendo na relação jurídica dois lados, um positivo e outro negativo, há de haver igualmente uma dualidade de sujeitos, um ativo, outro passivo; um que tem o poder jurídico, outro que assume o dever jurídico; um que pode exigir a realização, outro contra quem é dirigida a vontade do primeiro. $\mathrm{O}$ sujeito ativo tem a faculdade de reclamar o comando normativo; o sujeito passivo sofre a imposição da norma. O sujeito passivo pode ser determinado, como na relação creditória, ou indeterminado, como nos direitos reais. Desta maneira se fecha o pensamento jurídico: o sujeito ativo procede contra o sujeito passivo, mas não tem senhoria sobre ele; o sujeito ativo polariza o seu poder sobre a coisa, mas não se dirige contra ela; o sujeito passivo suporta a determinação do direito objetivo, para prestar ao sujeito ativo". 
Percorridos esse pontos principais da Teoria Pura do Direito, é possível fixar que o direito é a norma posta em caráter geral $^{41}$ ou individual, figurando nesta última hipótese a jurisprudência ${ }^{42}$ e o negócio jurídico ${ }^{43}$, que além de denotarem a aplicação do direito posto, também significam a sua produção ${ }^{44}$. Direito - Introdução à Problemática Científica do Direito - Versão Condensada pelo Próprio Autor, $4^{\text {a }}$ ed., São Paulo, RT, 2006, p. 104:

"Os graus mais próximos à Constituição são as normas gerais produzidas no processo legislativo, cuja função consiste não só em determinar os órgãos e o processo do conteúdo das normas individuais, comumente ditadas pelos tribunais e pelas autoridades administrativas, mas também, e principalmente, o conteúdo das mesmas (sic). Enquanto cabe à Constituição o pesado encargo de regular o procedimento da criação das leis, seu conteúdo, porém, só é determinado em muito pequena medida, sendo tarefa da legislação, do mesmo modo, a produção e a determinação do conteúdo dos atos judiciais e administrativos. (...)".

H. KelSEN, Reine Rechtslehre, 1934, trad. port. de J. Cretella Jr. e Agnes Cretella, Teoria Pura do Direito - Introdução à Problemática Científica do Direito - Versão Condensada pelo Próprio Autor, $4^{\text {a }}$ ed., São Paulo, RT, 2006, p. 106:

"A função da denominada jurisdição é muito mais constitutiva, criadora de direito, na verdadeira acepção da palavra. Pois existe uma situação de fato concreta, ligada a uma específica conseqüência jurídica, e toda essa relação é criada pela sentença judicial. Assim, como ambas as situações de fato são ligadas nas relações do geral pela lei, assim deverão estar unidas, na relação do individual, pela sentença judicial. Por isso é que a sentença judicial é uma norma jurídica individual, uma individualização ou concretização da norma geral ou abstrata, a continuação do processo de produção do direito, do geral para o individual. Somente o preconceito, de acordo com o qual todo direito está contido na norma geral, a identificação errônea do direito com a lei, poderia obscurecer esse ponto de vista".

H. KELSEN, Reine Rechtslehre, 1934, trad. port. de J. Cretella Jr. e Agnes Cretella, Teoria Pura do Direito - Introdução à Problemática Científica do Direito - Versão Condensada pelo Próprio Autor, $4^{\text {a }}$ ed., São Paulo, RT, 2006, p. 108:

"A individualização e concretização das normas gerais acontece em certas áreas jurídicas, como, por exemplo, no direito civil, não indiretamente, através de um ato funcional de órgão estatal, como é a sentença judicial. Nas normas jurídicas civis que se aplicam nos tribunais, entre a lei e a sentença judicial, interpõe-se o negócio jurídico, que, em relação à situação de fato condicionante, exerce uma função individualizadora.

Delegadas pela lei, as partes estabelecem normas concretas para o seu comportamento recíproco, normas que estabelecem um comportamento recíproco e cuja infração consiste na situação de fato verificada, criada pela sentença judicial, a qual está ligada à conseqüência do ilícito, isto é, à execução.

A última fase deste processo de produção jurídica, que tem seu começo na promulgação da Constituição, é a realização do ato coercitivo, como conseqüência da antijuridicidade".

H. KelSEN, Reine Rechtslehre, 1934, trad. port. de J. Cretella Jr. e Agnes Cretella, Teoria Pura do Direito - Introdução à Problemática Científica do Direito - Versão Condensada pelo Próprio Autor, $4^{\text {a }}$ ed., São Paulo, RT, 2006, p. 108:

"A maioria dos atos jurídicos é, ao mesmo tempo, ato de produção jurídica e ato executivo. Com cada um desses atos jurídicos será executada uma norma de grau mais alto e uma norma de grau inferior será produzida. Assim se apresenta o primeiro ato constituinte como execução da norma fundamental, a legislação - que é a produção de normas gerais como execução da Constituição, sentença judicial e ato administrativo, estabelecidas pela norma individual, como execução da lei, a realização de atos coercitivos, como execução de ordens administrativas e sentenças judiciais. $O$ ato coercitivo possui, sem dúvida, caráter de pura execução, assim como o pressuposto da norma fundamental possui caráter de puro projeto de normas. Mas tudo o que se acha entre esses dois casos limite é, ao mesmo tempo, produção e execução do direito". Negritou-se. 
Sem aderir à irretorquível posição de H. KELSEN acerca da inexistência dos nominados direitos subjetivos, E. BETTI leciona que a norma jurídica é composta por uma previsão de fato a qual o direito confere valor jurídico, chamada de fattispecie, e por uma disposição correspondente, ou seja, uma reação ou resposta à realidade social verificada que enseja a produção de uma nova situação ou relação jurídica. Destarte, concretizada a hipótese fática prevista em abstrato pela norma jurídica (fattispecie), opera-se o nexo de causalidade jurídica suficiente a fazer incidir à hipótese concreta a disposição suficiente a lhe modificar a situação jurídica ${ }^{45}$.

Esclarece o autor que o nexo fixado pela norma entre a fattispecie e a disposição pertinente não são fruto da causalidade natural, como se pode pensar na medida em que se nomina o surgimento do novo estado de direito como efeito jurídico. Na realidade, trata-se de relação de causalidade jurídica, cujas consequências verificadas são resultado da valoração jurídica que o ordenamento confere a determinadas hipóteses de fato, as quais concretizadas dão azo ao surgimento de uma nova situação jurídica ${ }^{46}$.

Essa construção lhe permite definir os fatos jurídicos como sendo "aqueles factos a que o direito atribui relevância juridica, no sentido de mudar as situações anteriores a eles e de configurar novas situações, a que correspondem novas qualificações jurídicas. O esquema lógico do facto jurídico, reduzido à expressão mais

E. BetTi, Teoria General del Negozio Giuridico, trad. port. de Fernando de Miranda, Teoria Geral do Negócio Jurídico, Tomo I, Coimbra, Coimbra, 1969, pp. 17 e 18:

"(...) A norma jurídica, considerada no seu arranjo lógico, consta de uma previsão e de uma disposição correspondente. Isto é, prevê, em abstracto e em geral, hipóteses de facto, classificadas por tipos e, ao mesmo tempo, orientadas segundo as directivas de uma valoração jurídica hipóteses que, em terminologia técnica, são denominadas fattispecie - e estabelece-lhes um tratamento apropriado, relacionando com elas, através de uma síntese normativa, como se fossem 'efeitos', situações jurídicas correspondentes. Logo que se realiza, em concreto, um facto ou uma relação da vida social, que, enquadrado na sua moldura circunstancial, apresente os requisitos previstos e corresponda ao tipo de fatispécie contemplado, intervém a síntese, o nexo estabelecido pela norma, de um modo hipotético, entre aquele tipo de fatispécie e a correspondente disposição: isto é, produz-se a nova situação jurídica disposta em previsão".

E. BetTI, Teoria General del Negozio Giuridico, trad. port. de Fernando de Miranda, Teoria Geral do Negócio Jurídico, Tomo I, Coimbra, Coimbra, 1969, pp. 18 e 19:

"E dado que esta, então, se produz automàticamente, no geral com uma constância e com uma necessidade inelutáveis, o nexo de carácter normativo estabelecido pela norma entre fatispécie e disposição é, no geral, comparado à causalidade natural, e concebido como um nexo de 'causalidade jurídica' (o que faz com que as novas situações jurídicas que se produzem, costumem ser denominadas 'efeitos jurídicos'). Há, porém, uma diferença essencial, que convém não esquecer: e é que os chamados 'efeitos jurídicos', ao contrário dos efeitos naturais, sendo o produto de uma valoração juridica, são uma criação do espirito humano, na medida em que ele reage sobre a realidade social. Eles representam a resposta que a ordem jurídica dá aos vários tipos de situações previstas: de maneira que a relação que aqui está em jogo, não é, pròpriamente, a de causa para efeito, mas aquela mesma que, na acti vidade humana, se estabelece entre a situação de facto e a acção que esta faz determinar. (...)". 
simples, obtém-se estudando-o como um facto dotado de certos requisitos pressupostos pela norma, o qual incide sobre uma situação pré-existente (inicial) e a transforma numa situação nova (final), de modo a constituir, modificar ou extinguir, poderes e vínculos, ou qualificações e posições jurídicas" 47 , de modo que o efeito constitutivo, modificativo ou extintivo atribuído aos fatos jurídicos deriva em última análise da norma jurídica que no seu esquema lógico prevê uma situação abstrata, para a qual acaso verificada, está disposta uma consequência que lhe altera a situação jurídica anterior fazendo surgir uma nova $^{48}$.

Por fim, a melhor doutrina clássica brasileira, embora também sem se libertar da tradicional separação, reconhece o direito como sendo o que se denomina direito objetivo, definindo-o como conjunto de preceitos coativos que integram a ordem jurídica e regulam a vida dos homens em sociedade ${ }^{49}$.

\section{b) Classificação}

No campo dos fatos jurídicos, a primeira distinção se pode estabelecer entre o fato jurídico natural e o fato jurídico voluntário, dizendo respeito o primeiro conceito aos fatos que independem da conduta humana, porém interessam ao homem porque

E. BetTI, Teoria General del Negozio Giuridico, trad. port. de Fernando de Miranda, Teoria Geral do Negócio Jurídico, Tomo I, Coimbra, Coimbra, 1969, p. 20.

E. BetTi, Teoria General del Negozio Giuridico, trad. port. de Fernando de Miranda, Teoria Geral do Negócio Jurídico, Tomo I, Coimbra, Coimbra, 1969, pp. 20 e 21:

"A eficácia constitutiva, modificativa ou extintiva, é atribuída ao facto jurídico em relação à situação em que se ele enquadra, na medida em que forma com ela (como fatispécie) um objecto de previsão e de valoração jurídica, por parte da norma que estabelece aquela eficácia. A valoração de um facto como facto jurídico exprime-se, precisamente, ao pôr em relação com a situação prevista, sobre a qual ele incide (fatispécie), uma situação jurídica nova, que se reporta à préexistente e é um desenvolvimento dela".

Clóvis Bevilaqua, Teoria Geral do Direito Civil, $7^{\mathrm{a}}$ ed., atual. por Achilles Bevilaqua e Isaias Bevilaqua, Rio de Janeiro, Francisco Alves, 1955, pp. 11 e 12:

"O direito, regra social obrigatória, é o que se costuma chamar direito objetivo, expressão das necessidades dos grupos sociais, sob a forma de preceitos coativos. Esta regulamentação dos interêsses humanos, segundo a idéia de justiça dominante no momento, constitui, quando considerada em seu conjunto, uma sistematização das energias sociais, que os juristas alemães, com muita propriedade, denominam ordem jurídica, o que importa dizer: justa proporção dos interêsses colidentes, ou antes, organização da vida em comum, pela proporcionada satisfação das necessidades e pela orientação cultural dos impulsos.

Psicològicamente, o direito é idéia, sentimento e poder de ação. Como idéia e sentimento, estuda-o particularmente a filosofia do direito. Como poder de ação será aqui considerado.

É o direito subjetivo que DERNBURG define uma faculdade concedida pela ordem jurídica ou a parte dos bens da existência, que cabe a uma pessoa na sociedade humana.

Neste sentido é que JHERING considera o direito um interêsse protegido pela lei". 
interferem em relações jurídicas ${ }^{50}$, enquanto os voluntários derivam da conduta humana comissiva ou omissiva, igualmente interferindo em relações sob a órbita do direito ${ }^{51}$.

Importa mencionar que essa classificação encontra resistência, e quem assim se posiciona a considera equívoca na medida em que possibilitaria designar o mesmo fato tanto como natural quanto como voluntário e consigna que a real distinção deve recair sobre a valoração do ordenamento jurídico acerca do fato, ou melhor dizendo, deve-se levar em conta o valor que a ordem jurídica confere à consciência que acompanha o comportamento humano e a vontade que o determina, de modo que se qualificam como atos jurídicos (lato sensu) as hipóteses em que o predito comportamento do agente tem relevância reconhecida pelo direito e se qualificam como fatos jurídicos (estricto sensu) aquelas hipóteses para as quais a ordem jurídica confere consequências prescindido da consciência e da vontade humanas ${ }^{52}$.

Caio Mário da SILVA PereIRA, Instituições de Direito Civil - Introdução ao Direito Civil - Teoria Geral do Direito Civil, vol. I, 23 ${ }^{a}$ ed. atualizada por Maria Celina Bodin de Moraes, Rio de Janeiro, Forense, 2010, p. 392:

"Os fatos jurídicos na sua acepção técnica podem desenrolar-se no campo da atividade humana, ou desta serem independentes, e, por tal razão, os escritores os classificam em duas ordens: fatos jurídicos voluntários e fatos jurídicos naturais.

Os naturais, independentes da vontade do homem, não são, porém, a ele estranhos, uma vez que atingem as relações jurídicas, e, como é o homem o seu sujeito, a ele interessam evidentemente. (...)".

51 Caio Mário da SILVA PereIRA, Instituições de Direito Civil - Introdução ao Direito Civil - Teoria Geral do Direito Civil, vol. I, $23^{\mathrm{a}}$ ed. atualizada por Maria Celina Bodin de Moraes, Rio de Janeiro, Forense, 2010, p. 393:

"Os voluntários resultam da atuação humana, positiva ou negativa, e, de uma ou de outra espécie, isto é, comissivos ou omissivos, influem sobre as relações de direito, variando as conseqüências em razão da qualidade da conduta e da intensidade da vontade. (...)".

E. BETTI, Teoria General del Negozio Giuridico, trad. port. de Fernando de Miranda, Teoria Geral do Negócio Jurídico, Tomo I, Coimbra, Coimbra, 1969, pp. 29 e 30:

"Para se decidir quando existe, ou não existe, um acto jurídico, é preciso usar da maior cautela, para não se ser inuzido a considerar como actos (jurídicos) factos que o não sejam. Uma doutrina corrente distingue entre factos voluntários (actos) e factos naturais (factos em sentido estrito). Mas, assim encarada, a distinção provém do aspecto já atrás apontado (...) e revela-se desprovida de interesse e, sobretudo, é equívoca. Na verdade, ela levaria a qualificar como natural e como voluntário o mesmo facto (por exemplo, a sementeira ou a plantação num terreno, ou a morte de uma pessoa), conforme ele, no caso específico, fosse, ou não, determinado pela vontade do homem.

$\mathrm{Na}$ realidade, a distinção entre actos e factos jurídicos, só tem sentido na medida em que tome por base o modo como a ordem juridica considera e valoriza um determinado facto. Se a ordem jurídica toma em consideração o comportamento do homem em si mesmo, e, ao atribuir-lhe efeitos juridicos, valoriza a consciência que, habitualmente, o acompanha, e a vontade que, normalmente, o determina, o facto deverá qualificar-se como acto juridico. Mas deverá, pelo contrário, qualificar-se como facto, quando o direito tem em conta o fenómeno natural como tal, prescindindo da eventual concorrência da vontade: ou então quando ele considera, realmente, a acção do homem sobre a natureza exterior, mas, ao fazê-lo, não valora tanto o acto humano em si mesmo, quanto o resultado de facto que ele tem em vista: quer dizer, a modificação objectiva que ele provoca no estado de coisas pré-existente". 
De todo o modo, tradicionalmente os fatos jurídicos em sentido largo (lato sensu) se dividem em "fatos jurídicos estricto sensu", que são os acontecimentos naturais, sem intervenção da vontade humana, mas com desdobramentos no âmbito do direito, e nos "atos jurídicos", sendo estes as ações ou inações humanas com repercussão jurídica ${ }^{53}$. É esta última categoria também a noção de "ato jurídico lato sensu”, que engloba os atos humanos aderentes ao direito e suficientes a produzir efeitos jurídicos independentemente de qualquer expressão de vontade e os atos humanos que canalizam uma manifestação de vontade e produzem os efeitos jurídicos também aderentes ao direito, mas neste caso desejados pelo agente ${ }^{54}$.

Nesse ponto, a doutrina se debateu entre os defensores da inexistência de qualquer distinção no campo dos atos jurídicos (corrente unitarista), sustentando a tese de que os fatos jurídicos oriundos da ação humana e fruto da vontade se enquadrariam dentro de um único conceito, independente dos seus efeitos jurídicos serem perseguidos pelo agente ou decorrentes do ordenamento jurídico. De outro lado, figuraram os defensores da dicotomia (corrente dualista), asseverando a diferença entre as hipóteses em que os efeitos jurídicos são meramente derivados da ordem jurídica e aquelas em que eles são resultados da autonomia da vontade do indivíduo ${ }^{55}$.

53 Orlando GoMES, Transformações Gerais do Direito das Obrigações, São Paulo, RT, 1967, p. 73:

“(...) Considerados fatos jurídicos os acontecimentos naturais ou ações humanas que recebem da lei significação própria, dividem-se, respectivamente, em fatos jurídicos estricto sensu e atos jurídicos. A qualificação dos acontecimentos naturais faz-se correntemente com a expressão fatos jurídicos, desacompanhada dos termos restritivos, raramente se empregando no sentido genérico, que compreende todos os atos jurídicos. Procede-se dêsse modo, por mais cômoda, a simplificação. Demais dessa razão ao se empregá-la, tem-se em vista, mais comumente, figurá-la como categoria que opõe à dos atos jurídicos, com a finalidade de separar inequìvocamente os fatos jurídicos oriundos dos acontecimentos naturais dos que resultam de ações humanas. Englobam-se estas na denominação genérica de atos jurídicos. (...)”.

Caio Mário da SIlva PereIRA, Instituições de Direito Civil - Introdução ao Direito Civil - Teoria Geral do Direito Civil, vol. I, $23^{\text {a }}$ ed. atualizada por Maria Celina Bodin de Moraes, Rio de Janeiro, Forense, 2010, p. 407:

“(...) Na mesma valoração ontológica da lei, como dos atos jurisdicionais, a vontade individual tem o poder de instituir resultados ou gerar efeitos jurídicos, e, então, a manifestação volitiva do homem, com o nome genérico de ato jurídico, enquadra-se entre as fontes criadoras de direitos (...). É a noção do ato jurídico lato sensu que abrange as ações humanas, tanto aquelas que são meramente obedientes à ordem constituída, determinantes de conseqüências jurídicas ex lege, independentemente de serem ou não queridas como aquelas outras declarações de vontade, polarizadas no sentido de uma finalidade, hábeis a produzir efeitos jurídicos queridos". José ABREU, O Negócio Jurídico e sua Teoria Geral, 2a ed., São Paulo, Saraiva, 1988, p. 15 :

"A quem se detenha a analisar a doutrina fica evidenciada a existência de duas posições antagônicas em torno do assunto. Um primeiro grupo de doutrinadores entende que inexistiria qualquer diferença entre ato e negócio jurídico, que, assim, significariam uma mesma coisa, atos que repercutiriam juridicamente, frutos da vontade humana; um outro movimento de opinião, contudo, propugna pela existência de nítidos traços diferenciais entre ato e negócio jurídico, 
Desse embate acerca da classificação dos atos jurídicos lato sensu, sobressaiu no plano doutrinário a corrente dualista, de modo que os nominados atos jurídicos se dividem em negócios jurídicos e atos jurídicos estricto sensu, atos não-negociais ou atos meramente lícitos ${ }^{56}$. Nestes, a despeito de também concorrerem a conduta humana e a prescrição normativa, os efeitos jurídicos verificados decorrem ex-lege, não sobressaindo o "valor plasmador" da vontade negocial que guia os efeitos jurídicos dos atos negociais ${ }^{57}$.

Lembrando que a doutrina tradicional tratava os negócios jurídicos tão somente como atos jurídicos, Caio Mário da Silva PEREIRA distingue-os também dos atos jurídicos estricto sensu, na medida em que estes produzem efeitos independentemente da vontade do agente, pois esses efeitos aflorariam de qualquer modo, uma vez que derivam da própria lei, enquanto os negócios jurídicos demandam a declaração de vontade do agente apta a produzir os efeitos desejados dentro de sua autonomia privada, mas que não são corolários diretos e necessários do ordenamento jurídico ${ }^{58}$,

embora provenham, ambos, da atividade volitiva do homem, sendo, assim, figuras autônomas, com características próprias. O primeiro movimento de opinião foi batizado de unitarismo (porque entendia unificados os conceitos de ato e negócio jurídico); o segundo ficou conhecido como corrente dualista (pelo fato de entender ser ato jurídico uma coisa e negócio jurídico outra)". Orlando GoMEs, Transformações Gerais do Direito das Obrigações, São Paulo, RT, 1967, p. 73 : “(...) Predomina, atualmente, a concepção dualista pela qual a expressão atos jurídicos compreende duas categorias de fatos jurídicos lato sensu, a dos negócios jurídicos e a dos atos jurídicos stricto sensu ou atos não-negociais. Desta corrente doutrinária, não se afastam quantos continuam a denominar atos jurídicos os negócios jurídicos, conceituando-os com os elementos característicos desta subespécie dos atos jurídicos lato sensu. Simplesmente não empregam a expressão negócio jurídico. Entre nós, sòmente nos últimos tempos essa expressão se vai tornando corrente no vocabulário jurídico. Os escritores mias antigos usavam invariàvelmente a expressão atos jurídicos (...)".

57 Clóvis V. do Couto E SILVA, A Obrigação como Processo, Rio de Janeiro, FGV, 2006, p. 73:

"Além dos negócios jurídicos, existem outros atos voluntários, denominados atos em sentido estrito. A eles são aplicáveis as disposições relativas ao negócio jurídico, quanto à nulidade, anulabilidade, capacidade, vícios da vontade etc. Alguns autores dão-lhes o nome de 'atos semelhantes aos negócios jurídicas', pelas razões acima apontadas. A diferença está em que, nestes, os efeitos derivam ex-lege. Não se pretende com isso dizer que os negócios jurídicos não dependam da incidência de lei. Certamente que existe essa dependência. Mas, no negócio jurídico, manifesta-se o valor plasmador da vontade, como em nenhum outro ato, de modo que, embora não se faça necessária a vontade de produzir efeitos jurídicos para a sua existência, esses efeitos, via de regra, equiparam-se e comensuram-se à vontade negocial. Ademais, faculta-se às partes determinarem, na forma que lhes aprouver, o conteúdo do ato; aporem condições, termos etc.

Nos atos em sentido estrito, qualquer que seja a vontade, os efeitos serão somente aqueles determinados pela lei. Assim, só para dar relevo a esse particular, diz-se que os efeitos derivam exlege".

58 Caio Mário da SILVA PereIRA, Instituições de Direito Civil - Introdução ao Direito Civil - Teoria Geral do Direito Civil, vol. I, $23^{\mathrm{a}}$ ed. atualizada por Maria Celina Bodin de Moraes, Rio de Janeiro, Forense, 2010, pp. 407 e 408 :

“Observa-se, então, que se distinguem o 'negócio jurídico' e o 'ato jurídico'. Aquele é a declaração de vontade, em que o agente persegue o efeito jurídico (Rechtsgeschäft); no ato jurídico stricto 
mas são perseguidos. Defende ainda que sendo o ato de vontade pressuposto do negócio jurídico, a sua exteriorização é necessária e ocorre por meio da declaração de vontade, entendida esta em sentido largo, visto que sendo apta a levar ao mundo exterior a vontade interna do agente pode se revestir de variadas formas ${ }^{59}$, no que se filia à teoria subjetiva.

Aproximando-se da teoria objetiva, Sílvio RODRIGUES confere relevo ao princípio da autonomia da vontade, visto que é esta externada em consonância com a norma jurídica de regência que permite que se atinjam os resultados jurídicos almejados. Figurando a norma como esquema de interpretação, a emissão de vontade em harmonia com a sua prescrição resulta na produção de outra norma jurídica de caráter particular e apta a disciplinar as relações jurídicas perseguidas pelo agente e prescritas pelo ordenamento, conferindo-lhe índole coercitiva, ou seja, na hipótese de comportamento contrário ao previsto na norma particular engendrada, haverá a incidência de sanção em desfavor daquele que assim proceder $^{60}$.

sensu ocorre manifestação volitiva também, mas os efeitos jurídicos são gerados independentemente de serem perseguidos diretamente pelo agente. (...) Todos eles são fatos humanos voluntários. Os 'negócios jurídicos' são, portanto, declarações de vontade destinadas à produção de efeitos jurídicos queridos pelo agente; os 'atos jurídicos stricto sensu' são manifestações de vontade, obedientes à lei, porém geradoras de efeitos que nascem da própria lei. Dentre os atos lícitos estão os atos que não são negócios jurídicos, bem como os negócios jurídicos. Todos, porém, compreendidos na categoria mais ampla de 'atos lícitos', que se distinguem, na sua etiologia e nos seus efeitos, dos 'atos ilícitos".

59 Caio Mário da SILva PEREIRA, Instituições de Direito Civil - Introdução ao Direito Civil - Teoria Geral do Direito Civil, vol. I, $23^{\text {a }}$ ed. atualizada por Maria Celina Bodin de Moraes, Rio de Janeiro, Forense, 2010, p. 413:

"Assentado, pois, que é a vontade o pressuposto do negócio jurídico, é imprescindível que ela se exteriorize e se divulgue por uma emissão, de forma a levar a deliberação interior ao mundo exterior. A vontade interna ou real é que traz a força jurígena, mas é a sua exteriorização pela declaração que a torna conhecida, o que permite dizer que a produção de efeitos é um resultado da vontade, mas que esta não basta sem a manifestação exterior.

Quando se fala em declaração de vontade, emprega-se a palavra em sentido lato. Não é mister que o agente faça uma declaração formal, através da palavra escrita ou falada. Basta que traduza o seu querer por uma atitude inequívoca, seja esta efetuada através do veículo habitual de expressão, seja por um gesto. (...)".

Sílvio Rodrigues, Direito Civil - Parte Geral, vol. 1, 34ª ed., São Paulo, Saraiva, 2007, p. 170:

"De fato. O negócio jurídico representa uma prerrogativa que o ordenamento jurídico confere ao indivíduo capaz de, por sua vontade, criar relações a que o direito empresta validade, uma vez que se conformem com a ordem social. A vontade procura um fim que não destoa da lei e que, por esse motivo, obtém dela a eficácia necessária.

O fim da declaração é produzir efeitos jurídicos imediatos, e, dada a liceidade do propósito, tais efeitos são efetivamente gerados. A esse princípio se chama autonomia da vontade. Representa a medida na qual o direito positivo reconhece aos indivíduos a possibilidade de praticar atos jurídicos, produzindo seus efeitos.

Uma vez estabelecida uma relação jurídica, por convenção entre os particulares, legalmente constituída, a lei lhe empresta sua força coercitiva e ela se torna obrigatória. Alguns códigos dizem 
De forma mais didática, W. BARros MonteIRo e Ana Cristina de Barros Monteiro FRAnÇA PINTO definem os fatos jurídicos (lato sensu) como sendo aqueles acontecimentos da natureza ou derivados da ação humana, previstos no ordenamento jurídico, que dão azo ao nascimento, subsistência ou perda de direitos ${ }^{61}$, os quais se subdividem nos fatos jurídicos estricto sensu e nos atos jurídicos lato sensu, repartindose este último conceito em negócios jurídicos, atos jurídicos lícitos ou estricto sensu e atos ilícitos ${ }^{62}$.

Tal é a proeminência dos negócios jurídicos para o direito privado, que o atual Código Civil Brasileiro lhe dedica ampla disciplina ${ }^{63}$, reservando aos atos jurídicos em sentido estrito tão somente um $\operatorname{artigo~}^{64}$, o qual se limita a dispor sobre a incidência no que couber das regras descritas para os atos negociais ${ }^{65}$.

que tal convenção tem força de lei. É o princípio de que pacta sunt servanda, o qual, embora muito atacado nos últimos tempos, e a despeito das exceções que nele se insinuam, continua a reger as relações privadas, pois, efetivamente e como ponto de partida, as convenções entre os particulares são válidas e geram efeitos, sempre que não colidirem com a lei de ordem pública. (...)". Negritouse.

61 Curso de Direito Civil - Parte Geral, vol. 1, 42a ed., São Paulo, Saraiva, 2010, p. 207:

"Pois bem, esses acontecimentos, de que decorrem o nascimento, a subsistência e a perda dos direitos, contemplados em lei, denominam-se fatos jurídicos (lato sensu)". Curso de Direito Civil - Parte Geral, vol. 1, 42ª ed., São Paulo, Saraiva, 2010, pp. 207 e 208:

Dentre esses fatos, uns são de ordem natural, alheios à vontade humana, ou para os quais essa vontade apenas concorre de modo indireto, tais como o nascimento, a maioridade, a interdição e a morte, em relação à pessoa natural; o desabamento de um edifício, o abandono do álveo pelo rio, a aluvião e a avulsão em relação às coisas; o decurso do tempo, o caso fortuito e a força maior, em relação aos direitos em geral.

Outros fatos, tão freqüentes como os primeiros, são as ações humanas. Entre estas, umas produzem efeitos jurídicos em consonância com a vontade do agente, que as pratica justamente para obter os resultados desejados. São os negócios jurídicos, como o casamento, o contrato, o testamento e a renúncia. Outras ações humanas produzem também efeitos jurídicos, mas sem qualquer atenção àquele elemento interno, psíquico, que é a vontade do agente. Os efeitos produzidos acham-se previamente delineados na lei como conseqüência fatal da prática daquela ação. São os atos jurídicos lícitos. Outros, enfim, procedem do agir humano, mas violam o direito: são os atos ilícitos".

Código Civil - artigos 104 a 188.

Código Civil:

“Art. 185 - Aos atos jurídicos lícitos, que não sejam negócios jurídicos, aplicam-se, no que couber, as disposições do Título anterior".

65 Caio Mário da SILVA PereIRA, Instituições de Direito Civil - Introdução ao Direito Civil - Teoria Geral do Direito Civil, vol. I, $23^{\mathrm{a}}$ ed. atualizada por Maria Celina Bodin de Moraes, Rio de Janeiro, Forense, 2010, p. 408:

"Aos atos jurídicos que não sejam negócios jurídicos (atos jurídicos lícitos ou atos jurídicos stricto sensu) são aplicáveis, no que couber, o disposto acerca dos negócios jurídicos (Código Civil, art. 185; Código Civil português, art. 295). Havendo o Código perfilhado a noção de negócio jurídico, considerou desnecessário repetir os mesmos conceitos em relação aos atos jurídicos que não constituam negócios jurídicos. Vale dizer: por extensão analógica, os requisitos de validade, as modalidades, os defeitos e a teoria das nulidades, construídas em tomo do negócio jurídico, aplicam-se aos atos jurídicos em geral”. 


\section{O Negócio Jurídico}

Retomando os postulados da Teoria Pura do Direito, consoante a qual o direito é fixado como uma ordem normativa capaz de disciplinar a conduta dos homens, tem-se que esse sistema de normas é valido na medida em que cada prescrição normativa encontra seu fundamento em uma prescrição (norma) superior, num sistema escalonado. Desse modo, as normas são vigentes porque estão fundamentadas em outra norma que lhes são superior e donde extraem sua validade, podendo se estabelecer um silogismo cuja premissa maior é a norma superior, a premissa menor é o fato da ordem do ser pelo qual a norma inferior é posta no ordenamento jurídico e a conclusão é a própria norma inferior válida. Nesse esquema de produção normativa, premissa maior e premissa menor são pressupostos da norma produzida, porém somente o dever ser da premissa maior é seu fundamento de validade ou sua conditio per quam, enquanto o fato do ser da premissa menor não fundamenta a norma produzida, mas a caracteriza e figura como conditio sine qua non para sua existência. A norma superior confere poder ou competência para que um órgão ou autoridade da comunidade jurídica estatuam a nova norma, de modo que o fundamento de validade encontra-se na prescrição que conferiu esse poder ou competência e não no ato do órgão ou da autoridade, embora esse ato do mundo do ser seja imprescindível para que a nova regra se torne vigente ${ }^{66}$.

H. KELSEN, Reine Rechtslehre, 1960, trad. port. de João Baptista Machado, Teoria Pura do Direito, $6^{\text {a }}$ ed., São Paulo, Martins Fontes, 1998, pp. 215 e 216:

"Dizer que uma norma que se refere à conduta de um indivíduo 'vale' (é 'vigente'), significa que ela é vinculativa, que o indivíduo se deve conduzir do modo prescrito pela norma. Já anteriormente num outro contexto, explicamos que a questão de porque é que a norma vale - quer dizer: por que é que o indivíduo se deve conduzir de tal forma - não pode ser respondida com a simples verificação de um fato da ordem do ser, que o fundamento de validade de uma norma não pode ser um tal fato. Do fato de algo ser não pode seguir-se que algo deve ser; assim como do fato de algo dever ser se não pode seguir que algo é. O fundamento de validade de uma norma apenas pode ser a validade de uma outra norma. Uma norma que representa o fundamento de validade de uma outra norma é figurativamente designada como norma superior, por confronto com uma norma que é, em relação a ela, a norma inferior. Na verdade, parece que se poderia fundamentar a validade de uma norma com o fato de ela ser posta por qualquer autoridade, por um ser humano ou suprahumano: assim acontece quando se fundamenta a validade dos Dez Mandamentos com o fato de Deus, Jeová, os ter dado no Monte Sinai; ou quando se diz que devemos amar os nossos inimigos porque Jesus, o Filho de Deus, o ordenou no Sermão da Montanha. Em ambos os casos, porém, o fundamento de validade, não expresso mas pressuposto, não é o fato de Deus ou o Filho de Deus ter posto uma determinada norma num certo tempo e lugar, mas uma norma: a norma segundo a qual devemos obedecer às ordens ou mandamentos de Deus, ou aquela outra segundo a qual devemos obedecer aos mandamentos de Seu Filho. Em todo caso, no silogismo cuja premissa maior é a proposição de dever ser que enuncia a norma superior: devemos obedecer aos mandamentos de Deus (ou aos mandamentos de Seu Filho), e cuja conclusão é a proposição de dever-ser que enuncia a norma inferior: devemos obedecer aos Dez Mandamentos (ou ao mandamento que nos ordena que amemos os inimigos), a proposição que verifica (afirma) um fato 
Depreende-se que esse sistema escalonado de normas jurídicas, no qual normas inferiores encontram seu fundamento de validade nas normas que figuram num plano superior, não pode se estender ad infinintum, ou seja, o sistema demanda um fecho, que reside numa norma que não encontra sua validade em outra que lhe é superior porque ela é a última e a mais elevada e diferente das demais normas não é posta por nenhum órgão ou autoridade da comunidade jurídica, mas é pressuposta num exercício lógico. Chamada de norma fundamental (Grundnorm), ela é o fundamento de todas as demais normas pertencentes à ordem normativa, figurando como elo de unidade do sistema positivo $^{67}$.

Dentro do sistema escalonado em que as normas superiores conferem validade às inferiores, abaixo da norma fundamental pressuposta está a constituição, por óbvio, buscando seu fundamento na Grundnorm. Em seguida, figuram a legislação e o costume, como normas gerais contendo prescrições abstratas, cujo fundamento de validade, mas não necessariamente o seu conteúdo, uma vez que se trata de um sistema dinâmico, deriva da constituição, devendo ser destacado que o costume somente

da ordem do ser: Deus estabeleceu os Dez Mandamentos (ou o Filho de Deus ordenou que amássemos os inimigos), constitui, como premissa menor, um elo essencial. Premissa maior e premissa menor, ambas são pressupostos da conclusão. Porém apenas a premissa maior, que é uma proposição de dever-ser, é conditio per quam relativamente à conclusão, que também é uma proposição de dever-ser. Quer dizer, a norma afirmada na conclusão. A proposição de ser que funciona como premissa menor é apenas conditio sine qua non relativamente à conclusão. Quer dizer: o fato da ordem do ser verificado (afirmado) na premissa menor não é o fundamento de validade da norma afirmada na conclusão".

H. KELSEN, Reine Rechtslehre, 1960, trad. port. de João Baptista Machado, Teoria Pura do Direito, 6a ed., São Paulo, Martins Fontes, 1998, p. 217:

"Como já notamos, a norma que representa o fundamento de validade de uma outra norma é, em face desta, uma norma superior. Mas a indagação do fundamento de validade de uma norma não pode, tal como a investigação da causa de um determinado efeito, perder-se no interminável. Tem de terminar numa norma mais elevada, ela tem de ser pressuposta, visto que não pode ser posta por uma autoridade, cuja competência teria de se fundar numa norma ainda mais elevada. A sua validade já não pode ser derivada de uma norma mais elevada, o fundamento da sua validade já não pode ser posto em questão. Uma tal norma, pressuposta como a mais elevada, será aqui designada como norma fundamental (Grundnorm). (...).

Todas as normas cuja validade pode ser reconduzida a uma e mesma norma fundamental formam um sistema de normas, uma ordem normativa. A norma fundamental é a fonte comum da validade de todas as normas pertencentes a uma e mesma ordem normativa, o seu fundamento de validade comum. $\mathrm{O}$ fato de uma norma pertencer a uma determinada ordem normativa baseia-se em que o seu último fundamento de validade é a norma funda mental desta ordem. É a norma fundamental que constitui a unidade de uma pluralidade de normas enquanto representa o fundamento da validade de todas as normas pertencentes a essa ordem normativa". 
ostentará o sentido objetivo de dever ser se a constituição assim lhe prestar esse fundamento ${ }^{68}$.

Nesse patamar das normas gerais produzidas conforme a prescrição da constituição, costuma-se fixar a subdivisão entre leis e decretos, conforme o órgão legiferante competente seja um parlamento eleito pelo povo ou a própria administração pública, sendo os atos normativos nessa ultima hipótese nominados decretos-leis. A distinção também aparece na medida em que a constituição possa conferir competência para o parlamento fixar as normas gerais, mas também permita à administração pública editar normas pormenorizadas das regras gerais ${ }^{69}$.

Superado o escalão das normas gerais, faz-se necessário repisar que no sistema normativo teorizado por KELSEN, a aplicação e a produção normativa são fenômenos simultâneos, de forma que ao passo que a norma superior é aplicada e confere fundamento a uma norma inferior, verifica-se também a produção de um novo ato normativo. Tal ocorre também na medida em que a aplicação das normas gerais fundamentam a edição de normas de caráter individual, conferindo-lhes vigência.

H. KELSEN, Reine Rechtslehre, 1960, trad. port. de João Baptista Machado, Teoria Pura do Direito, $6^{\text {a }}$ ed., São Paulo, Martins Fontes, 1998, pp. 250 e 251:

"As normas jurídicas gerais criadas pela via legislativa são normas conscientemente postas, quer dizer, normas estatuídas. Os atos que constituem o fato legislação são atos produtores de normas, são atos instituidores de normas; quer dizer: o seu sentido subjetivo é um dever-ser. Através da Constituição, este sentido subjetivo é alçado a uma significação objetiva, o fato legislativo é instituído como fato produtor de Direito. A Constituição também pode, porém, instituir como fato produtor de Direito um determinado fato consuetudinário. Este fato, como já foi referido acima, é caracterizado pela circunstância de os indivíduos pertencentes à comunidade jurídica se conduzirem por forma sempre idêntica sob certas e determinadas circunstâncias, de esta conduta se processar por um tempo suficientemente longo, de por essa forma surgir, nos indivíduos que, através dos seus atos, constituem o costume, a vontade coletiva de que assim nos conduza mos.

Então, o sentido subjetivo do fato que constitui o costume é um dever-ser: o sentido de que nos devemos conduzir de acordo com o costume. O sentido subjetivo do fato consuetudinário só pode, porém, ser pensado como norma jurídica objetivamente válida se este fato assim qualificado é inserido na Constituição como fato produtor de normas jurídicas".

H. KELSEN, Reine Rechtslehre, 1960, trad. port. de João Baptista Machado, Teoria Pura do Direito, $6^{\text {a }}$ ed., São Paulo, Martins Fontes, 1998, p. 255:

"O escalão da produção de normas gerais - regulada pela Constituição - é por sua vez geralmente subdividido, na conformação positiva das ordens jurídicas estaduais, em dois ou mais escalões. Aqui poremos em destaque apenas a distinção entre lei e decreto, que é de particular importância onde a Constituição atribua fundamentalmente a produção das normas jurídicas gerais a um parlamento eleito pelo povo, permitindo, porém, a elaboração mais pormenorizada das leis por meio de normas gerais que são editadas por certos órgãos da administração, ou onde, para certos casos excepcionais, dê ao governo competência para, no lugar do parlamento, editar todas as normas gerais necessárias ou apenas certas normas gerais. As normas gerais que provêm não do parlamento, mas de uma autoridade administrativa, são designadas como decretos, que podem ser decretos regulamentares ou decretos-leis. Estes últimos são também chamados decretos com força de lei. (...)". 
Ressalvas, nesse tocante, devem ser feitas em relação aos dois extremos do sistema, uma vez que a norma fundamental não é produzida e tem sua validade pressuposta, assim como a imputação de um ato coercitivo prescrito por uma norma individual também não redunda na produção de uma nova norma, mas tão somente encerra o sistema, o qual tem sua gênese na aplicação da sanção. No mais, ou seja, relevados os extremos, aplicação e produção de normas andam juntas, especialmente na edição das normas individuais ${ }^{70}$.

Nesse espectro das normas individuais, aparecem as decisões judiciais, ou o que se convencionou chamar de jurisprudência, como produto do sistema normativo escalonado. No processo de produção normativa, a jurisprudência traduz a individualização ou concretização da normas gerais abstratas, permitindo, em última ratio, a imputação da sanção ao indivíduo cuja conduta verificada pelo processo competente destoou da prescrição legal, restando enfatizar que não se trata de mera dicção do direito posto, mas de criação de norma jurídica suficiente a regular uma determinada conduta específica ${ }^{71}$.

H. KELSEN, Reine Rechtslehre, 1960, trad. port. de João Baptista Machado, Teoria Pura do Direito, 6 ed., São Paulo, Martins Fontes, 1998, pp. 260 e 261:

"Uma norma que regula a produção de outra norma é aplicada na produção, que ela regula, dessa outra norma. A aplicação do direito é simultaneamente produção do Direito. Estes dois conceitos não representam, como pensa a teoria tradicional, uma oposição absoluta. É desacertado distinguir entre atos de criação e atos de aplicação do Direito. Com efeito, se deixarmos de lado os casoslimite - a pressuposição da norma fundamental e a execução do ato coercivo - entre os quais se desenvolve o processo jurídico, todo ato jurídico é simultaneamente aplicação de uma norma superior e produção, regulada por esta norma, de uma norma inferior. Se considerarmos a ordem jurídica estadual sem ter em conta um Direito internacional que lhe esteja supra-ordenado, então a norma fundamental determina, de fato, a criação da Constituição, sem que ela própria seja, ao mesmo tempo, aplicação de uma norma superior. Mas a criação da Constituição realiza-se por aplicação da norma fundamental. Por aplicação da Constituição, opera-se a criação das normas jurídicas gerais através da legislação e do costume; e, em aplicação destas normas gerais, realizase a criação das normas individuais através das decisão judiciais e das resoluções administrativas. Somente a execução do ato coercivo estatuído por estas normas individuais - o último ato do processo de produção jurídica - se opera em aplicação das normas individuais que a determinam sem que seja, ela própria, criação de uma norma. A aplicação do Direito é, por conseguinte, criação de uma norma inferior com base numa norma superior ou execução do ato coercivo estatuído por uma norma".

H. KELSEN, Reine Rechtslehre, 1960, trad. port. de João Baptista Machado, Teoria Pura do Direito, $6^{\text {a }}$ ed., São Paulo, Martins Fontes, 1998, pp. 263 e 264:

"Do ponto de vista de uma consideração centrada sobre a dinâmica do Direito, o estabelecimento da norma individual pelo tribunal representa um estádio intermediário do processo que co meça com a elaboração da Constituição e segue, através da legislação e do costume, até a decisão judicial e desta até a execução da sanção. Este processo, no qual o Direito como que se recria em cada momento, parte do geral (ou abstrato) para o individual (ou concreto). É um processo de individualização ou concretização sempre crescente. 
Prepondera, outrossim, ainda no âmbito das normas individuais derivadas dos sistema normativo também o negócio jurídico, igualmente compreendido com norma jurídica, porque deriva sua validade de normas gerais que permitem aos indivíduos regularem suas condutas de determinada maneira, ensejando ainda àquela parte da relação negocial cuja conduta oposta à prescrita no negócio se verificar a imputação de uma sanção também prescrita nas normas gerais que conferiram a faculdade de autoregulação por meio do negócio jurídico ${ }^{72}$.

\section{a) As Teorias}

Historicamente pioneiras e ainda predominantes na doutrina estrangeira, bem como entre os autores clássicos nacionais ${ }^{73}$, são as teorias voluntaristas, as quais

Para individualizar a norma geral por ele aplicada, o tribunal tem de verificar se, no caso que se lhe apresenta, existem in concreto os pressupostos de uma conseqüência do ilícito determinados in abstracto por uma norma geral. Esta determinação do fato que condiciona as conseqüências do ilícito implica a determinação da norma geral a aplicar, isto é, a averiguação de que está em vigor uma norma geral que liga uma sanção ao fato (ou , situação de fato) em apreço. O tribunal não só tem de responder à quaestio facti como também à quaestio juris. Depois de realizadas estas duas averiguações, o que o tribunal tem a fazer é ordenar in concreto a sanção estatuída in abstracto na norma jurídica geral. Estas averiguações e esta ordem ou comando são as funções essenciais da decisão judicial".

72 H. KELSEN, Reine Rechtslehre, 1960, trad. port. de João Baptista Machado, Teoria Pura do Direito, $6^{\text {a }}$ ed., São Paulo, Martins Fontes, 1998, pp. 284 e 285:

"Uma conduta pode ser havida como contrária ao negócio jurídico porque o sentido subjetivo do ato ou dos atos que formam um negócio jurídico é uma norma, porque o negócio jurídico é um fato produtor de normas. Na linguagem tradicional a palavra 'negócio jurídico' é usada tanto para significar o ato produtor da norma como ainda a norma produzida pelo ato. O negócio jurídico típico é o contrato. Num contrato as partes contratantes acordam em que devem conduzir-se de determinada maneira, uma em face da outra. Este dever-ser é o sentido subjetivo do ato jurídico negocial. Mas também é o seu sentido objetivo. Quer dizer: este ato é um fato produtor de Direito se e na medida em que a ordem jurídica confere a tal fato esta qualidade; e ela confere-lhe esta qualidade tornando a prática do fato jurídico-negocial, juntamente com a conduta contrária ao negócio jurídico, pressuposto de uma sanção civil. Na medida em que a ordem jurídica institui o negócio jurídico como fato produtor de Direito, confere aos indivíduos que lhe estão subordinados o poder de regular as suas relações mútuas, dentro dos quadros das normas gerais criadas por via legislativa ou consuetudinária, através de normas criadas pela via jurídico-negocial. Estas normas jurídico-negocialmente criadas, que não estatuem sanções mas uma conduta cuja conduta oposta é o pressuposto da sanção que as normas jurídicas gerais estatuem, não são normas jurídicas autônomas. Elas apenas são normas jurídicas em combinação com as normas gerais que estatuem as sanções. (...)".

73 Clovis Bevilaqua, Teoria Geral do Direito Civil, $7^{\mathrm{a}}$ ed., atual. Achilles Bevilaqua e Isaias Bevilaqua, Rio de Janeiro, Francisco Alves, 1955, p. 198:

"Na sistemática alemã, embora haja tendência a estabelecer-se distinção entre atos jurídicos e declarações de vontade, geralmente as duas expressões se consideram equipolentes. Savigny ensina: 'Chama-se declaração de vontade a classe de fatos jurídicos, que não somente são atos livres, mas ainda, segundo a vontade do agente, têm por fim imediato criar ou dissolver uma relação de direito'. Windscheid, por seu lado, escreve: 'ato jurídico é uma declaração da vontade individual, tendo em vista produzir um efeito jurídico'. É claro que a vontade individual só por si não tem fôrça para criar, modificar ou extinguir direitos; é preciso que ela se manifeste segundo a ordem jurídica. É o que ficou, anteriormente, afirmado, e fêz sentir Kohler, quando definiu atos 
enfrentam o negócio jurídico como manifestação ou declaração de vontade com escopo de produzir efeitos jurídicos ou efeitos práticos tutelados pela ordem jurídica ${ }^{74}$.

Posteriormente, ainda dentro do campo voluntarista, abre-se o debate entre os partidários da teoria da vontade (Willenstheorie) e os adeptos da teoria da declaração (Erklarungstheorie), defendendo os segundos o predomínio da vontade declarada sobre aquela subjetivamente verificada no íntimo do indivíduo.

Filiando-se à posição doutrinária voluntarista e enfatizando a preponderância da vontade na caracterização do negócio jurídico, além de fixar a relação de causalidade entre a vontade validamente manifestada e a intenção de gerar efeitos jurídicos por meio do ato negocial ${ }^{75}$, José ABREU em seu magistério também esclarece a contenda travada entre os voluntaristas e os declaracionistas, lembrando que os primeiros julgavam necessária a harmonia entre o conteúdo da declaração (meio de manifestação da vontade) e a real intenção do indivíduo na busca dos efeitos jurídicos pertinentes, enquanto para os sectários da teoria da declaração bastaria a exteriorização da vontade, nenhuma relevância conferindo eles à intenção do agente ${ }^{76}$.

jurídicos 'ações que, pelo direito, são destinadas a influir na vida jurídica em virtude de sua natureza lógica'. As declarações de vontade são, como diz Sohm, 'a fôrça que mantém o mundo das relações jurídicas de ordem privada em movimento ininterrupto".

74 Antônio Junqueira de AzEVEDo, Negócio Jurídico - Existência, Validade e Eficácia, 4ª ed., São Paulo, Saraiva, 2007, p. 4:

"As definições do negócio jurídico, como ato de vontade, são as mais antigas na ordem histórica e talvez se possa dizer que, até hoje, mesmo na doutrina estrangeira, são elas ainda as mais comuns. Fala-se, então, para conceituar o negócio jurídico, em manifestação de vontade destinada a produzir efeitos jurídicos, ou em ato de vontade dirigido a fins práticos tutelados pelo ordenamento jurídico, ou, ainda, em declaração de vontade (adotada, porém, esta última expressão em sentido pouco preciso, através do qual não se a distingue de manifestação de vontade).

As definições voluntaristas são indubitavelmente dominantes na doutrina brasileira, na qual, aliás, com poucas exceções, nem se quer se cogita da concepção oposta; correspondem elas, grosso modo, à definição que o art. 81 no Código Civil brasileiro dá ao 'ato jurídico'. (...)". Negritou-se. José ABReu, O Negócio Jurídico e sua Teoria Geral, 2a ed., São Paulo, Saraiva, 1988, pp. 32 e 33: "É a vontade, portanto, sem sombra de dúvida, o cerne do próprio negócio jurídico que nela tem sua gênese e pela qual dita sua própria estrutura. Uma e outra (gênese e estrutura) resultam sempre do elemento volitivo. A vontade, portanto, será a causa. Os efeitos dela emergem. O elemento volitivo assume, assim, papel preponderante e fundamental na caracterização do negócio jurídico, De todos os fatos voluntários (ou fatos conforme a vontade humana) é o negócio jurídico, sem dúvida, aquele em que a vontade assume maiores proporções e se evidencia de forma mais destacada. Daí a observação precisa de Windscheid, para quem o negócio jurídico nada mais é que uma 'declaração de vontade, privada, manifestada de modo válido, no intuito de produzir efeitos jurídicos'. Nota-se aquela relação de causalidade, muito bem posta na conceituação, entre a vontade e a intenção de gerar os efeitos jurídicos. (...)".

76 José Abreu, O Negócio Jurídico e sua Teoria Geral, 2ª ed., São Paulo, Saraiva, 1988, pp. 54 e 55: "Consoante se assinala, com muita propriedade, os juristas se dividem na aferição do papel da vontade. Em derredor do assunto se consolidaram duas posições antagônicas, separando-se os 
Mas que realmente se opõem às teorias voluntaristas são as denominadas teorias objetivas ou preceptivas, que encaram o negócio jurídico como um fato concreto ao qual o ordenamento jurídico reconhece validade normativa ${ }^{77}$.

\section{a.1) Teoria Subjetiva}

Definindo o negócio jurídico como "manifestação de vontade dirigida a um fim prático tutelado pelo ordenamento jurídico" e esclarecendo ser este fim o regramento dos próprios interesses, L. CARIOTA FERRARA assegura tratar-se do instrumento mais qualificado da autonomia privada, na medida em que autorregula a esfera jurídica do indivíduo por meio da sua vontade ${ }^{78}$.

Pondera que a autonomia privada encontra limites, não sendo dado ao sujeito regular qualquer interesse, mas somente aqueles dignos de guarida no ordenamento jurídico, como também não pode regular seus interesses de qualquer modo, mas deve observar os parâmetros normativos fixados. Assim, o negócio jurídico deve ganhar

juristas em duas fronteiras distintas. De um lado os partidários da teoria da vontade; de outro, os prosélitos da teoria da declaração - propugnando os primeiros (voluntaristas) que deveria haver uma sintonia entre a declaração (como meio hábil à exteriorização da vontade) e a intenção, entendida esta última como o desejo de obter determinadas conseqüências jurídicas. (...)

Já os prosélitos da teoria da declaração entendem que, ao contrário, o que importa é a emissão desta, sendo desimportante a aferição de sua vinculação à intenção do agente. A declaração valeria per si mesma, independentemente da intenção. O debate tem grande importância e sobretudo sabor prático, uma vez que a aceitação de um ou outro posicionamento se reflete na indagação pertinente aos chamados vícios do consentimento, ecoando, ainda, na problemática da interpretação dos negócios jurídicos. (...)

A nós nos parece que a teoria da vontade deve merecer as preferências, porque nos convence a colocação dos prosélitos desta teoria ao pregarem a necessidade de uma harmonia entre o ato declarativo e a intenção. A declaração, para validar-se juridicamente, deve sintonizar-se com o querer interno, isto é, com a intenção do agente. (...)".

Antônio Junqueira de AZEVEDo, Negócio Jurídico - Existência, Validade e Eficácia, 4ª ed., São Paulo, Saraiva, 2007, pp. 11 e 12:

"Concepção, porém, realmente oposta à referida no $\S 1^{\circ}$ é a que Scognamiglio denomina 'teoria preceptiva'; enumera o mesmo autor, entre os seguidores dessa teoria, Bullow, Henle e Larenz, na Alemanha, e, na Itália, Betti. Para os partidários dessa teoria, o negócio jurídico constitui um comando concreto ao qual o ordenamento jurídico reconhece eficácia vinculante. (...)".

78 L. CARIOTA Ferrara, Il Negozio Giuridico nel Diritto Italiano, trad. esp. de Manuel Albaladejo, El Negocio Jurídico, Madrid, Aguilar, 1956, pp. 43 e 44:

"Entre los actos jurídicos lícitos tienen particular naturaleza y valor los negocios jurídicos.

Estos son manifestaciones de voluntad dirigidas a un fin práctico tutelado por el ordenamiento jurídico.

El fin perseguido es, generalmente, regular los propios intereses en la vida social, como, por ejemplo, disponer de los propios bienes.

EI negocio jurídico en cuanto constituye uno de los medios para la autorregulación de los propios intereses, en cuanto es medio de actuación del dominio de la voluntad en la esfera jurídica propia del sujeto, es el instrumento más calificado de la autonomía privada". 
exteriorização nos moldes legalmente preconizados, com observância, por exemplo, dos requisitos de partes capazes, objeto lícito e forma prescrita ou não vedada, visto que inobservados os ditames do ordenamento não subsistirá a regulação desejada ${ }^{79}$.

Outra limitação importante à autonomia privada deriva dos tipos negociais, por vezes previstos em lei e dos quais não é permitido ao particular se afastar, visto que negado reconhecimento de negócios atípicos em determinadas searas do direito privado. Da mesma forma, os negócios jurídicos encontram também limitação nas normas cogentes ou de ordem pública, cujos efeitos jurídicos prescritos não podem ser afastados pela vontade das partes, mas, ao revés, devem necessariamente prevalecer $^{80}$.

Prosseguindo na exposição, assevera que a vontade é essencial ao negócio jurídico e adentra na discussão se os seus efeitos têm causa na vontade do agente ou no ordenamento jurídico, lembrando que três correntes se debatem nesse tocante, a primeira no sentido de que os efeitos jurídicos derivam exclusivamente da vontade, a segunda redarguindo que derivam tão somente da ordem jurídica e uma terceira sustentando a conjugação de ambos como causa, ou seja, a junção da vontade particular com a estatal ${ }^{81}$.

L. CAriota Ferrara, Il Negozio Giuridico nel Diritto Italiano, trad. esp. de Manuel Albaladejo, El Negocio Jurídico, Madrid, Aguilar, 1956, p. 45:

"Ante todo, un límite de la autonomía privada, en su extrinsecación, deriva de las normas ordinativas atinentes al negocio jurídico. La voluntad del particular es considerada eficaz en tanto en cuanto el negocio en el que encarna reúna los requisitos exigidos por la ley: forma, capacidad, causa, etc.

En otros términos, la voluntad del sujeto consigue regular de modo seguro sus intereses, en tanto en cuanto concurren los extremos que la ley exige para el negocio en general o para aquel tipo de negocio en especial. De otra manera, el negocio cae o puede caer, y con él la regulación. (...)". L. CARIOTA Ferrara, Il Negozio Giuridico nel Diritto Italiano, trad. esp. de Manuel Albaladejo, El Negocio Jurídico, Madrid, Aguilar, 1956, pp. 45 e 46:

"Otro límite: al particular no le está permitido siempre y en cualquier materia crear un negocio que reúna los requisitos generales, pero que no encaje en ninguno de los tipos previstos por la ley (negocio atípico). Esto no le está permitido, p. ej., en materia de relaciones de familia. En tal campo, se le deja, cuando más, la posibilidad de crear una serie de situaciones de hecho.

Además, si el particular ha elegido o ha debido elegir un tipo de negocio, no siempre puede eliminar los efectos que la ley liga a dicho tipo. Ello, p. ej., está prohibido en materia de relaciones de familia. En general, son inmutables aquellas consecuencias que se hallan consagradas en normas cogentes o inderogables (contrapuestas a las dispositivas)".

81 L. CARIOTA Ferrara, Il Negozio Giuridico nel Diritto Italiano, trad. esp. de Manuel Albaladejo, El Negocio Jurídico, Madrid, Aguilar, 1956, p. 47:

"De todo cuanto se ha dicho sobre la distinción entre negocio jurídico y acto jurídico, de la definición que ya se ha dado de aquél y de lo que se ha indicado sobre la autonomía de la voluntad, se puede fácilmente deducir que la voluntad es esencial en el negocio. La relevancia que, como veremos, se da a ésta, a su dirección y a su contenido por el ordenamiento es la consagración jurídica de ello. 
Consagra-se, portanto, a vontade como causa preponderante dos efeitos dos negócios jurídicos e ao mesmo tempo se fixa a sua direção, isto é, a que se dirige a vontade do agente: ao propósito jurídico ou ao propósito prático do negócio jurídico, sendo este outro ponto sobre o qual se debate a doutrina ${ }^{82}$. Defende o autor que como a vontade deve necessariamente ostentar uma finalidade esta é a finalidade prática, ou seja, sobressai no ato voluntário do indivíduo a finalidade empírica, até mesmo porque os efeitos jurídicos, por vezes, não são sequer conhecidos ou previstos, e mesmo que indesejados se verificam assim mesmo, o que denota seu afastamento como causa presente na vontade negocial ${ }^{83}$.

Superando o debate acerca da preponderância da vontade, como elemento anímico, ou da sua declaração, entendida esta com a manifestação da primeira suficiente a externá-la como elemento constitutivo do negócio jurídico, CARIOTA FERRARA fixa ambas, vontade e declaração, como essenciais, porém obtempera que o princípio da vontade encontra limites nos princípios da responsabilidade e da confiança ${ }^{84}$, ou

Y ahora se impone el examen de un viejo problema: causa de los efectos jurídicos, ¿es la voluntad del particular o el orden jurídico? Según algunos, el orden jurídico es la sola verdadera causa de los efectos jurídicos y la voluntad negocial confina con la zona del hecho y tiene la simple función de determinar o condicionar la norma. Otros sostienen la tesis opuesta, dando valor causal (es decir, valor de causa efficiens de los efectos jurídicos) a la voluntad del particular. Otros, aun conciliando las soluciones opuestas, ven la causa, en la voluntad privada y en la del Estado unidas". Negritou-se.

L. CARIOTA Ferrara, Il Negozio Giuridico nel Diritto Italiano, trad. esp. de Manuel Albaladejo, El Negocio Jurídico, Madrid, Aguilar, 1956, p. 50:

"Además, con la definición dada, hemos acogido una de las soluciones propuesta por la doctrina para un grave y debatido problema: el de a qué se dirige la voluntad negocial. Según una opinión lo es a los efectos jurídicos (el denominado propósito jurídico); según otra lo es al fin práctico (el denominado propósito empírico o práctico); según una tercera, que es atenuación de la primera, la voluntad se dirige a un efecto jurídico en general".

83 L. CARIOTA FerRARA, Il Negozio Giuridico nel Diritto Italiano, trad. esp. de Manuel Albaladejo, El Negocio Jurídico, Madrid, Aguilar, 1956, pp. 50 e 51:

"(...) En efecto, en la realidad la voluntad del sujeto o de los sujetos tiende a un resultado práctico, y ni conoce ni prevé los efectos jurídicos que se le ligan. Estos, por otro lado, se verifican incluso si no fueron jamás previstos. No se diga que es preciso al menos que la voluntad tienda hacia un fin jurídico en general, pues ello, indudablemente, se encuentra en la mayor parte de los casos concretos, pero es innegable que el negocio produce sus efectos incluso si falta tal tendencia. Con razón ha sido negado que la concordancia de los efectos jurídicos con la función o razón (causa) deba, ella misma, ser querida".

84 L. CARIOTA FERRARA, Il Negozio Giuridico nel Diritto Italiano, trad. esp. de Manuel Albaladejo, El Negocio Jurídico, Madrid, Aguilar, 1956, pp. 52 e 53:

"La voluntad, sin embargo, no se considera, por el ordenamiento jurídico, de por sí, sino que ella se integra con la manifestación, otro elemento constitutivo del negocio: la propia voluntad se valora en tanto y por cuanto ha sido manifestada.

(...)

Pero hay más. EI principio de autonomía de la voluntad no impera de modo absoluto, pues en tal caso cualquier falta o vicio de la voluntad debería producir la invalidez del negocio. Y, por el contrario, nadie puede invocar su desconocimiento de la juridicidad o de algunos efectos jurídicos 
melhor, a vontade não pode ser considerada inexistente ou viciada se para tanto concorreu com dolo ou culpa a parte que o sustenta ou se a outra parte do negócio tinha razões para confiar na higidez da declaração voluntária. Conclui, assim, por uma posição intermediária no tocante à prevalência da vontade ou da declaração, visto que as soluções extremas deságuam em inegáveis distorções, como a desvalorização completa da manifestação da vontade no primeiro caso ou a desconsideração do querer na segunda hipótese ${ }^{85}$.

Desse modo, sem descuido da importância tanto da vontade, quanto da sua declaração, mas sem adotar posição sectária em relação a qualquer da duas, e agregando que devem encontrar limites na responsabilidade das partes, bem como na sua confiança e na dos terceiros, e ainda lembrando que a causa dos efeitos do negócio são as finalidades práticas perseguidas pelos agentes, pode-se definir, sob essa ótica, o negócio jurídico como "manifestação de vontade que se dirige a um fim prático, e que o ordenamento jurídico protege, tendo em conta também a responsabilidade do ou dos sujeitos e a confiança deles e dos demais" ${ }^{86}$.

del acto que ha realizado. Ni la falta o vicios de la voluntad atinentes al contenido de la manifestación (simulación, error, etc.), y ni siquiera la falta de voluntad de la manifestación pueden invocarse, si son debidos a culpa o dolo del que los sufre o si la otra parte o los terceros han confiado o han tenido razones para confiar en una voluntad existente y carente de vicioso.

Ninguna falta o vicio del querer puede ser invocado si es responsable el sujeto, en el sentido de que éste se haya comportado diversamente de como lo habría hecho un hombre de diligencia y prudencia ordinarias, o sea un hombre de negocios de tipo medio de aquel lugar y de aquel tiempo. Todo cuanto precede significa que son esenciales la voluntad y la declaración, y que el principio de voluntad está limitado por el de responsabilidad combinado con otro, con el de confianza". L. CARIOTA Ferrara, Il Negozio Giuridico nel Diritto Italiano, trad. esp. de Manuel Albaladejo, El Negocio Jurídico, Madrid, Aguilar, 1956, pp. 55 a 57:

"De cuanto precede se deduce que nosotros lo mismo en el terreno dogmático que en el del Derecho positivo, creemos debe preferirse respecto a la naturaleza y a la disciplina del negocio y, consiguientemente, respecto al problema de la relación entre voluntad y declaración (manifestación), una solución intermedia, conciliadora del valor de la voluntad con el de la declaración, y suavizada por la influencia de la responsabilidad y de la confianza. Esta es la posición que debe tomarse, en nuestra opinión, respecto a las varias teorías formuladas en materia de relación entre voluntad y declaración.

(...)

Estos temperamentos y estas limitaciones son la mejor prueba de la insostenibilidad de las teorías extremas. La sostenedora del dogma de la voluntad, aparte de no responder a la vida práctica y a las exigencias y deberes que incumben a quien vive en el mundo jurídico, comete el error de desconocer, en su primera configuración, el valor de la declaración. Sus propios defensores, han corregido tal error (Windscheid) y se han situado en el justo medio, como se ha visto.

La teoría de la declaración adolece del vicio opuesto, desconociendo el valor del querer, o bien sustituyendo el querer real por uno inexistente".

86 L. CARIOTA FerRARA, Il Negozio Giuridico nel Diritto Italiano, trad. esp. de Manuel Albaladejo, El Negocio Jurídico, Madrid, Aguilar, 1956, p. 58: 


\section{a.2) Teoria Objetiva}

Sustentando a teoria oposta, E. BETTI propugna que os negócios jurídicos têm sua gênese no seio da própria sociedade, ou melhor, na iniciativa privada do seus membros, que têm a necessidade de conforme os seus interesses fazer circular os bens e serviços de que são titulares. São os negócios jurídicos ações de auto-regulação que os indivíduos estabelecem entre si, num primeiro momento independente de qualquer regramento jurídico, como mecanismo de satisfação de seus interesses e necessidades no tocante à circulação dos bens que lhes são colocados à disposição. Frisa que inicialmente os vínculos são fixados tão somente por meio da palavra empenhada e da boa-fé existente entre os concidadãos, figurando como sanção apenas a ojeriza que poderá advir do corpo social em desfavor do indivíduo faltoso nas suas relações. É somente mais tarde que o direito reconhece a autonomia privada dos indivíduos e agasalha sob o seu manto as suas práticas e mecanismos de circulação de bens e satisfação de interesses, alçando-as ao patamar de negócios jurídicos, bem como impingindo-lhes sanções jurídicas verificadas em desfavor de eventuais negociantes recalcitrantes com os seus deveres de conduta ${ }^{87}$.

"Pero innegablemente la voluntad sigue siendo elemento esencial de negocio. Innegablemente el principio de voluntad se limita, pero no se excluye, por los de responsabilidad y de confianza. Igualmente sigue siendo elemento esencial la manifestación. Por tanto, en nuestra opinión, es muy justa y legítima la definición que pone de relieve, como esencia del negocio jurídico, la manifestación de voluntad. Incluso caído el dogma de la voluntad, el negocio jurídico es para nosotros 'manifestación de voluntad dirigida a un fin práctico'. Sólo hay que añadir que el ordenamiento lo tutela 'teniendo en cuenta la responsabilidad del sujeto y la confianza de los demás'. De tal manera, junto a la voluntad y la manifestación, resultan expresados en la definición los límites que derivan, para el imperio del querer, del principio de responsabilidad combinado con el de confianza.

Nosotros nos detenemos, así, en el punto medio entre las teorías opuestas, pensando que esta vez, 'in medio stat veritas'.

Para nosotros, pues, el negocio jurídico hay que definir-lo como 'manifestación de voluntad que se dirige a un fin práctico, y que el ordenamiento jurídico tutela, teniendo en cuenta también la responsabilidad del o de los sujetos y la confianza de los demás".

E. BetTi, Teoria General del Negozio Giuridico, trad. port. de Fernando de Miranda, Teoria Geral do Negócio Jurídico, Tomo I, Coimbra, Coimbra, 1969, pp. 91 e 92:

"Esta génese, que os negócios jurídicos costumam ter no terreno social, de acordo com a necessidade da circulação dos bens, mostra, claramente, que eles germinam da iniciativa privada e são, essencialmente, actos por meio das quais os particulares procuram satisfazer a necessidade de regular por si mesmos os seus interesses nas relações recíprocas: actos de auto-determinação, de auto-regulamentação dos seus próprios interesses. Auto-regulamentação que a consciência social já considera vinculativa para as partes, mesmo antes do acto ser elevado à dignidade de negócio jurídico: quer dizer, ele é considerado, não como um programa puro e simples, a que as partes podem, livremente, ater-se ou não (tal como poderia acontecer com um propósito individual, formado no íntimo da consciência), mas como um critério vinculante, como uma regra de conduta, que tem de ser observada e que, no caso de inobservância, é acompanhada, na vida social, por sanções, mais ou menos enérgicas e seguras, tanto de carácter especifico (ex.: medidas de retorsão 
Ressalta, outrossim, que essa possibilidade de fixação de relações ancoradas na autonomia privada dos indivíduos somente tem ambiente para crescer e evoluir para a órbita do direito naquelas comunidades econômicas e jurídicas que asseguram aos seus membros a propriedade individual de uma parcela dos bens, possibilitando-lhes, assim, empreender a sua circulação ${ }^{88}$.

Prosseguindo na análise, o autor reconhecendo a inquestionável necessidade e interesse dos povos em fazer circular bens e serviços, conclui que o direito na sua função reguladora acolherá também mecanismos que ordenem essas práticas vitais, ostentando desse modo duas funções, uma estática, tendente à conservação e proteção do status quo, e outra dinâmica, esta permissiva da perene necessidade de circulação de riquezas. Nesse ponto, filiando-se à corrente tradicional que estabelece a dicotomia entre o direito objetivo e o direito subjetivo, estabelece um paralelo entre o negócio jurídico, entendido como mecanismo reconhecido pelo ordenamento jurídico suficiente a permitir o estabelecimento de liames jurídicos entre os indivíduos, permitindo-os, desse modo, satisfazer interesses e necessidades, e o direito subjetivo, este com a finalidade estática de tutelar os interesses privados tal como se encontram, protegendoos de ameaças. E conclui que tanto o direito subjetivo quanto o negócio jurídico derivam da autonomia privada dos indivíduos, que reconhecida pelo ordenamento jurídico, assevera-lhes tanto a conservação dos seus interesses como a possibilidade de colocá-los em circulação para satisfação de necessidades ${ }^{89}$.

e de auto-tutela) como de carácter genérico (ex.: perda ou diminuição do crédito social, com a consequente impossibilidade, ou dificuldade, de realizar novos negócios). A sanção do direito apresenta-se como qualquer coisa acrescentada e lògicamente posterior: mais precisamente, como um reconhecimento de autonomia. Em consequência desse reconhecimento, os negócios da vida privada elevam-se à dignidade de negócios jurídicos e tomam-se instrumentos, que o próprio direito põe à disposição dos particulares, para servirem de base aos seus interesses na vida de relação, por conseguinte, para dar vida e permitir o desenvolvimento das relações entre eles: e portanto, continuarão também a ser actos de autonomia privada".

E. BetTI, Teoria General del Negozio Giuridico, trad. port. de Fernando de Miranda, Teoria Geral do Negócio Jurídico, Tomo I, Coimbra, Coimbra, 1969, pp. 92 e 93:

"Naturalmente, porém, a necessidade de negócios entre um indivíduo e outro, só se vê claramente naqueles ordenamentos económico-sociais que reconhecem aos individuos um um conjunto de bens que lhes competem, isto é, nos ordenamentos baseados no reconhecimento da propriedade individual. Efectivamente, só com base nesse reconhecimento, a circulação dos bens, assim como a prestação de serviços entre os indivíduos, são entregues, necessàriamente, à autonomia privada. (...)".

89 E. BETTI, Teoria General del Negozio Giuridico, trad. port. de Fernando de Miranda, Teoria Geral do Negócio Jurídico, Tomo I, Coimbra, Coimbra, 1969, pp. 95 a 97:

"Se a circulação dos bens e dos serviços, como, de um modo geral, o desenvolvimento de relações entre os indivíduos, representa uma necessidade vital de qualquer sociedade, é óbvio que também 
Noutro ponto em que E. BetTI se afasta da Teoria Pura do Direito de H. Kelsen é no tocante à consideração do negócio jurídico em ralação ao ordenamento jurídico, uma vez que o mestre italiano, diferente do mestre de Viena, faz distinção entre a produção e aplicação das normas jurídicas, situando no primeiro campo tão somente aquelas hipóteses em que a ordem constitucional erige determinados membros da comunidade jurídica a órgãos legiferantes, reconhecendo-lhes a produção normativa como válida. Já no segundo campo, figuram os negócios jurídicos, não alçados à condição de norma individual, mas entendidos como causa geradora de relações jurídicas já de antemão previstas no plano abstrato pelo ordenamento jurídico. Estabelece-se a distinção entre autonomia criadora de normas jurídicas e autonomia criadora de relações jurídicas, cuidando a primeira das hipóteses de delegação da competência normativa para determinados particulares e a segunda das modalidades de fattispecie que previstas em abstrato pelo direito, quando verificadas em concreto, geram relações jurídicas entre os particulares, imputando-lhes sanções caso sua conduta

o direito, na função ordenadora a que é destinado no âmbito do organismo social (ubi societas ibi jus), deve corresponder à mesma exigência. (...). Além da função, em si mesma estática, de proteger a actual distribuição, mediante a atribuição de direitos subjectivos aos presentes detentores, o direito tem, também, a , função dinâmica de lhe tornar possível a perene renovação, de facilitar a circulação dos bens e a recíproca utilização dos serviços, em conformidade com as necessidades que vão surgindo sucessivamente. E porque, num ordenamento baseado na propriedade individual dos individuos consociados, essa renovação é obra da autonomia privada (§1), a solução do problema está em reconhecer essa autonomia, e em lhe elevar algumas manifestações à categoria de negócios jurídicos: o que equivale a dizer, a instrumentos para dar vida e desenvolvimento a relações jurídicas entre os individuos. O instituto do negócio jurídico representa, assim, a solução de um problema prático, paralelo ao que é resolvido com a figura do direito subjectivo privado. Ambos (direito e negócio) estão ao serviço da liberdade e da autonomia privada, mas com finalidades essencialmente diferentes, visto cada um dos dois representar a solução jurídica de um problema prático diferente, embora correlativo. O direito subjectivo tem uma finalidade estática, de conservação e de tutela. O negócio jurídico tem, pelo contrário, uma finalidade dinâmica, de iniciativa e de renovação. Com o direito subjectivo, a ordem jurídica resolve o problema de proteger os interesses privados, tais como os encontra constituídos na ordem econômico-social que tutela. Com o negócio jurídico, ela resolve o problema de dar à iniciativa individual um modo de se manifestar e de se mover, modificando a posição de tais interesses de acordo com as directrizes que os próprios particulares julguem mais convenientes. Tanto o direito subjectivo privado, como o negócio jurídico, são dominados pelo princípio da liberdade e da consequente auto-responsabilidade privada (...). O indivíduo é livre de agir segundo a sua maneira de ver: isto desde que, por outro lado, só ele sofra as consequências da sua conduta, quer elas sejam, para ele, vantajosas ou onerosas. O direito subjectivo também não é uma coisa que ao particular seja distribuída do alto, e como que imposta e assegurada por acção automática da lei, sem seu conhecimento e sem intervenção da sua vontade. É, em vez disso, frequentemente obtido graças a uma actividade própria, capaz . de pôr em movimento o mecanismo da norma juridica; e é uma coisa que, uma vez obtida, é conservada e defendida, com um esforço sempre atento, contra a ameaça e o ataque alheios". 
destoe daquela prevista como efeito do vínculo fixado, nesse ponto reservando-se o campo da autonomia privada ${ }^{90}$.

Colocadas essas premissas e sem perder de vista que o reconhecimento jurídico da autonomia privada, materializada no negócio jurídico, é a solução para a necessidade de satisfazer o interesse social na circulação de riquezas, define-se o negócio jurídico como o "acto pelo qual o indivíduo regula, por si, os seus interesses, nas relações com outros (acto de autonomia privada): acto ao qual o direito liga efeitos mais conformes à função económico-social que lhe caracteriza o tipo (típica neste sentido)"191.

E desta construção, é possível extrair a forma, o conteúdo e a causa do negócio jurídico, elementos fundamentais para alicerçar a teoria objetiva ou preceptiva defendida por BETTI em sua obra.

E. BetTI, Teoria General del Negozio Giuridico, trad. port. de Fernando de Miranda, Teoria Geral do Negócio Jurídico, Tomo I, Coimbra, Coimbra, 1969, pp. 97 a 99:

"A autonomia - como autoridade, e como potestas, de auto-regulamentação dos próprios interesses e relações, exercidas pelo próprio titular deles - pode ser reconhecida pela ordem juridica estadual com duas funções distintas e diversas: a) Pode ser reconhecida como fonte de normas jurídicas, destinadas a fazer parte integrante da própria ordem jurídica, que a reconhece, precisamente, como fonte de direito subordinada e dependente; $b$ ) Pode ser, além disso, reconhecida como pressuposto e causa geradora de relações jurídicas já disciplinadas, em abstracto e em geral, pelas normas dessa ordem jurídica.

Aqui só interessa considerar a autonomia privada. Esta autonomia é reconhecida pela ordem juridica, no campo do direito privado, exclusivamente na segunda das indicadas funções. É, portanto, reconhecida como actividade e potestas, criadora, modificadora ou extintora de relações jurídicas entre particulares: relações cuja vida e cujas vicissitudes, são, antecipadamente, disciplinadas por normas jurídicas preexistentes. A manifestação precípua desta autonomia é o negócio jurídico, o qual, precisamente, é concebido como um acto de autonomia privada, a que o direito liga o nascimento, a modificação ou a extinção de relações jurídicas entre particulares.Estes efeitos jurídicos produzem-se na medida em que são previstos por normas que, tomando por pressuposto de facto o acto de autonomia privada, os ligam a ele como sendo a fatispécie necessária e suficiente.

Também a autonomia privada configura um auto-regulamento, e até, ainda mais, um regulamento directo, individual, concreto, de determinados interesses pessoais, efectivado pelos próprios particulares interessados. Entre o interesse regulado, o poder e a vontade reguladora (é este o ponto característico), há aqui uma coincidência imediata: porque são interesse, poder e vontade das próprias pessoas. $\mathrm{Na}$ autonomia criadora de normas jurídicas, o ordenamento estadual reconhece uma verdadeira e própria fonte de direito objectivo, dentro da órbita de competência que lhe é própria $a b$ origine. Pelo contrário, na autonomia criadora de relações juridicas, a ordem juridica limita-se a reconhecer aos indivíduos o poder de criar fatispécies aptas a gerar vínculos entre eles. A autonomia privada tem, portanto, caracteres próprios, claros e inconfundíveis com os de qualquer outra autonomia".

91 E. BETTI, Teoria General del Negozio Giuridico, trad. port. de Fernando de Miranda, Teoria Geral do Negócio Jurídico, Tomo I, Coimbra, Coimbra, 1969, pp. 107 e 108:

"Passando, após estas premissas, a determinar o conceito do negócio jurídico, não devemos perder de vista o problema prático, de que a autonomia privada e o seu reconhecimento juridico representam a solução. (...). Ele , é o acto pelo qual o indivíduo regula, por si, os seus interesses, nas relações com outros (acto de autonomia privada): acto ao qual o direito liga os efeitos mais conformes à função económico-social que lhe caracteriza o tipo (típica neste sentido)". 
A forma do negócio jurídico é um ato humano consistente numa declaração ou em um comportamento, suficientes a conferir a este fato do mundo externo a recognoscibilidade, ou seja, que permita ao ato humano ser reconhecido socialmente para que sobre ele incida a correspondente fattispecie prevista no ordenamento jurídico, gerando os efeitos dispostos pela norma e dando azo ao surgimento de uma nova situação jurídica. Ponto relevante é a exigência da recognoscibilidade social da declaração ou do comportamento, porque justamente afasta em definitivo do conteúdo e da causa dos negócios jurídicos o dogma da vontade, encarada esta como fato psicológico interno ao absoluto alvedrio do seu agente e indene de qualquer forma de controle ou verificação. A vontade do agente somente ostenta relevância na gênese do negócio, contudo na medida em que atinge o mundo externo por meio de uma declaração ou comportamento e estes se apresentam socialmente recognoscíveis, ela vai ocupar lugar em segundo plano ${ }^{92}$.

O conteúdo do negócio jurídico é uma disposição, ancorada na autonomia privada, esta assegurada pelo ordenamento, que tem o escopo de regular uma relação jurídica fixada para satisfazer interesses e necessidades das partes negociantes. Trata-se, em última análise de um preceito de caráter dispositivo e vinculativo. Novamente é preciso destacar que nessa medida, a declaração ou comportamento socialmente recognoscíveis não são mera manifestação ou complemento comprobatório de um

92 E. BetTI, Teoria General del Negozio Giuridico, trad. port. de Fernando de Miranda, Teoria Geral do Negócio Jurídico, Tomo I, Coimbra, Coimbra, 1969, pp. 108 e 109:

"À primeira pergunta deve responder-se que o negócio é um acto que ora consiste numa declaração, ora num simples comportamento (...). Se qualquer negócio é, essencialmente, um facto social, e a autonomia privada é um fenómeno social, é fácil compreender que o negócio jurídico deve, também, satisfazer àquela exigência de recognoscibilidade que domina toda a vida social, isto é, deve ser um facto socialmente reconhecível. A exigência de recogniscibilidade encontra-se em todo o campo da vida de relaçao, quer se trate de entender as manifestações da espiritualidade alheia, quer se trate de regular relações entre sócios. Efectivamente, só pelo trâmite de formas representativas idóneas para conservar a marca do seu autor e a tornar reconhecível o sentido nelas objectivado, os homens podem chegar a entender-se entre eles e constituir, nas relações reciprocas, comunhões de espiritualidade. Se, numa hipótese absurda, se experimentasse imaginar estar suprimido esse trâmite entre os seres humanos, a consequência seria que eles não poderiam voltar a comunicar uns com os outros, e seria destruida, com a possibilidade de se compreenderem e de regularem as relações recíprocas, toda a vida social. Ora, este dado elementar da experiência, é perdido de vista por quem, através de uma elipse inconsciente, descobre na 'vontade', tanto o objecto da ínterpretação, como a essência do negócio jurídico. Na verdade, a 'vontade', como facto psicológico meramente interno, é qualquer coisa em si mesma incompreensível e incontrolável, que pertence, unicamente, ao foro intimo da consciência individual. Só na medida em que se torne reconhecível no ambiente social, quer por declarações, quer por comportamentos, ela passa a ser um facto social, susceptível de interpretação e de valoração, por parte dos consociados. Sòmente declarações ou comportamentos são entidades socialmente reconheciveis e, portanto, capazes de poder constituir objecto de interpretação, ou instrumento de autonomia privada. (...)". 
estado de foro íntimo, mas figuram como uma estatuição operativa suficiente a regular no plano social a conduta dos indivíduos que em seguida subsume-se à fattispecie correspondente e produz os efeitos previstos pela ordem jurídica ${ }^{93}$.

E a causa do negócio jurídico, como já se enfatizou, é a satisfação do interesse ou necessidade de caráter econômico e social perseguidos pelos agentes e agasalhados como juridicamente relevantes pela ordem jurídica, que assim lhes confere disciplina (previsão ou fattispecie) e lhes assegura consequências jurídicas (disposição) ${ }^{94}$.

Desse modo, BETTI espanca o dogma da vontade, repisando que no negócio jurídico o indivíduo não se limita a querer ou declarar que quer, mas pelo contrário manifesta e externa uma conduta que terá o condão de vinculá-lo a um futuro comportamento ou submetê-lo à imputação de uma sanção, caso sua conduta seja posteriormente verificada em desconformidade com o preceito disposto pelo ordenamento jurídico. Reconhece, é bem verdade, que a vontade figura na gênese do fato ainda na órbita da autonomia privada, todavia, no âmbito do negócio jurídica é relegada a segundo plano, na medida em que prepondera a declaração ou comportamento socialmente recognoscíveis, sendo ainda verdade que os efeitos dispostos pela ordem jurídica independem da vontade que nesse momento já se perfez e

E. BetTI, Teoria General del Negozio Giuridico, trad. port. de Fernando de Miranda, Teoria Geral do Negócio Jurídico, Tomo I, Coimbra, Coimbra, 1969, pp. 110 e 111:

"À segunda pergunta, responde-se que o negócio contém, e é, essencialmente, uma estatuição, uma disposição, um preceito da autonomia privada, dirigido a interesses concretos próprios de quem o estabelece: preceito destinado a ter eficácia constitutiva, isto é, a realizar, imediatamente, os efeitos ordenativos correspondentes, na vida de relação. A declaração tem, portanto, natureza preceptiva ou dispositiva, e por conseguinte carácter vinculativo; o comportamento tem, semelhantemente, só por si esse carácter. Com isto pretende dizer-se que declaração e comportamento não são simples revelação externa, manifestação complementar de um estado de espírito interno, ou de um propósito, não são mera enunciação ou indício de um conteúdo psicológico, cuja existência seja juridicamente relevante como tal e demonstrável por outro modo; enunciação ou indício com pura eficácia representativa ou probatória, e sem eficácia operativa própria (...). Contra esta visão dualista, mantém-se firmemente que declaração e comportamento são a estatuição ordenadora de uma linha de conduta, em confronto com outras disposições, por meio das quais o indivíduo regula as suas relações com outros, e que têm, portanto, uma relevância essencialmente social e uma eficácia operativa própria, que não é válida de outra forma: eficácia que, primeiro, se manifesta, lògicamente, no plano social, e depois, graças à sanção do direito, se destina a produzir-se também no plano jurídico".

E. BetTI, Teoria General del Negozio Giuridico, trad. port. de Fernando de Miranda, Teoria Geral do Negócio Jurídico, Tomo I, Coimbra, Coimbra, 1969, p. 111:

"Finalmente, à terceira pergunta, deve responder-se que qualquer tipo de negócio serve uma função económico-social característica dele (tipica, neste sentido), a qual, ao mesmo tempo que é, normalmente, tida em conta por quem o realiza (e desse modo constitui a sua intenção prática típica), é tomada em consideração pelo direito, qualquer que seja a razão justificativa da garantia e a sanção juridica, e seja qual fôr o critério directivo para a configuração de efeitos ordenativos conformes a ela. (...)". 
cedeu lugar à firme resolução emanada no sentido de perseguir e atingir interesses ou satisfazer necessidades do futuro (causa do negócio) ${ }^{95}$.

Finalmente, o autor pondera que mesmo que não possa superar em definitivo o dualismo que resiste entre a declaração (significado objetivo) e a sua percepção pelo indivíduo (significado subjetivo), muda-se a perspectiva de observação e valoração, visto que a vontade terá sempre caráter psicológico e interno e o preceito ostentará condão socialmente percebido ${ }^{96}$. E obtempera que para as hipóteses em que há desconformidade entre a vontade e o preceito ou entre este e aquela, lança-se mão da auto-responsabilidade e da legitimação. Primeiro se verifica se o indivíduo que alega dissonância da sua vontade com o preceito não deve suportar os efeitos do negócio jurídico, não porque os perseguisse, mas porque objetivamente fez crer à comunidade jurídica e às outras partes que objetivamente ostentava aquele interesse que deu causa ao negócio. E no segundo caso, há de se indagar se o preceito objetivamente verificado

E. BetTI, Teoria General del Negozio Giuridico, trad. port. de Fernando de Miranda, Teoria Geral do Negócio Jurídico, Tomo I, Coimbra, Coimbra, 1969, pp. 112 a 114:

"(...) Com o negócio, o inditvíduo não se limita a declarar que quer alguma coisa, mas declara, para os outros, o objecto do seu querer: e deve ser um regulamento vinculativo, o que ele estabelece no seu interesse, para as relações com os outros. Com o negócio, ele não pode limitar-se a manifestar um estado de espírito, um modo de ser do querer, que teria uma importância psicológica puramente individual; mas deve apontar um critério de conduta, estabelecer uma relação de valor normativo (...). A questão diz respeito, não já ao carácter de acto voluntário, que qualquer negócio deve ter, mas. à função da vontade, ao lugar que lhe deve ser atribuído na estrutura de um facto social, como é a manifestação da autonomia privada na vida de relação. Não se nega que, na normalidade dos casos, o individuo declare ou faça qualquer coisa querida. Negase, apenas, que a vontade se encontre, no negócio, em primeiro plano, e que a concordância entre os efeitos jurídicos e a função ou razão (causa) do negócio, também deva, ela própria, ser querida, como se pretende quando se postula uma vontade individual orientada para os efeitos jurídicos. Efectivamente, não deve esquecer-se que, no momento em que o negócio se realiza, o processo volitivo deve ter, e normalmente já o fez, percorrido o seu iter, e atingido a sua meta definitiva: ele já se esgotou e concretizou numa resolução firme, e os efeitos são determinados pela ordem jurídica, em conformidade com a função do negócio. O teor de um negócio qualquer, mostra bem que nele ocupa o primeiro plano o regulamento de interesses disposto para o futuro, ao passo que a vontade apenas está em segundo plano, como dirigida à função prática daquele: ela pertence, efectivamente, à génese, mas não ao conteúdo do acto de autonomia como facto soacial". E. BetTI, Teoria General del Negozio Giuridico, trad. port. de Fernando de Miranda, Teoria Geral do Negócio Jurídico, Tomo I, Coimbra, Coimbra, 1969, pp.141 e 142:

"(...) De resto, mesmo configurando o conteúdo do negócio como preceito da autonomia privada, não se supera, é verdade, o inevitável dualismo entre a declaração e a actividade preceptiva que nela deveria estar realizada, entre o significado social (objectivo) do negócio e a apreciação individual (subjectiva) que dele faz o autor da declaração. Mas muda, necessàriamente, o ponto de vista, a perspectiva, da qual o dualismo deve ser olhado e valorado. Ao passo que a 'vontade', seja como for que a encaremos, será sempre uma coisa interna, inseparável da pessoa e, portanto, qualquer coisa incontrolável, o preceito é, conceitualmente, uma coisa 'estabelecida' a respeito de esferas de interesses interferentes, é uma atitude exprimida externamente no ambiente social, e, por isso, verificável sem possibilidade de equívoco. (...)". 
derivou da declaração ou comportamento de agentes que ostentavam legitimidade para dispor acerca do interesse objeto do negócio jurídico ${ }^{97}$.

\section{b) Definiçãa}

Na doutrina brasileira, como já enfatizado, prevalece a posição voluntarista, liderada pelo próprio Clovis BEVILAQUA, quem assim se posiciona ao comentar o artigo 85 de seu velho Código Civil de 1916, equiparando a declaração de vontade ao conceito de ato jurídico e asseverando figurar a vontade como seu núcleo essencial ${ }^{98}$.

De Portugal e ainda na vigência das Ordenações do Reino, também se filiou à teoria da vontade o lente da Universidade de Coimbra M. A. COELHO DA ROCHA, para quem o ato jurídico é todo fato ou omissão resultado da razão humana e suficiente a criar, extinguir ou alterar direitos ou obrigações ${ }^{99}$, enfatizando também o mestre

E. BetTI, Teoria General del Negozio Giuridico, trad. port. de Fernando de Miranda, Teoria Geral do Negócio Jurídico, Tomo I, Coimbra, Coimbra, 1969, pp. 144 e 145:

"Para quem considere o negócio sob este aspecto, surge, portanto, e põe-se, necessàriamente, o problema da auto-responsabilidade, isto é, o problema de saber se o autor do negócio não deverá, porventura, suportar as consequências, que sejam para ele prejudiciais, dependentes da impressão suscitada, da confiança razoável radicada nos 'outros', a quem o preceito era destinado ou, por qualquer modo, dizia respeito, sem que possa considerar-se decisiva, em sentido contrário, a prova de que ele não queria aquelas consequências, ou não pensava nelas. Aparece e impõe-se, igualmente, o problema da legitimação e dos seus limites. Porque, se o negócio é um acto de autonomia, que tem relevância social em relação a outros consociados (mesmo quando tenha estrutura unilateral), evidentemente já não bastará perguntar se o autor o quer e tinha capacidade para querê-lo, mas iteressa também, e sobretudo, saber se ele podia ou não dar-lhe vida, dentro de que limites e por que caminhos o podia fazer. O preceito do negócio é não só, e não tanto, o resultado normal de uma vontade (isto não passa de um dos seus aspectos), mas é, sobretudo, a manifestação de um poder, no círculo dos consociados. Manifestação - disciplinada por normas de validade e de competência - daquele poder de autonomia, que é, acima de tudo, uma realidade da vida social, e encontra a sua legitimidade no reconhecimento juridico".

98 Clovis Bevilaqua, Codigo Civil dos Estados Unidos do Brazil, vol. I, Rio de Janeiro, Francisco Alves, 1916, p. 351:

"Neste artigo, o Codigo emprega a expressão - declaração de vontade, que é o conteudo do acto juridico, pelo proprio acto. Num sentido geral, podem, realmente, as duas locuções se equivaler.

A vontade manifesta-se por signaes ou symbolos, entre os quaes occupam logar proeminente as palavras. Esses signaes ou palavras podem não traduzir, fielmente, o que o agente quer exprimir. A lei, por isso, manda attender, de preferencia, á intenção, desde que haja elementos para delerminala, fóra da expressão verbal imperfeita, indecisa, obscura ou insuficiente.

Este preceito é mais do que uma regra de interpretação. E' um elemento complementar do conceito do acto juridico. Affirma que a parte essencial ou nuclear do acto juridico é a vontade. E' a ella, quando manifestada de accordo com a lei, que o direito dá efficacia". Instituições de Direito Civil, Tomo I, São Paulo, Saraiva, 1984, p. 50:

"\$94. Diz-se ato, ou ação, neste sentido, todo fato, ou omissão, praticado por uma pessoa no uso da sua razão. Quando desta ação resulta a criação, extinção, ou alteração de direitos, ou obrigações, é um ato de direito. Estes atos podem ser lícitos, ou ilícitos. Os atos ilícitos não podem produzir direitos para seus autores, mas produzem obrigações - Código da Prússia, P. 1, Tít. 3, art. 35. Além disto em alguns atos dá-se a manifestação da vontade, a qual é considerada como a base da aquisição ou alteração dos direitos: a estes chamamos propriamente atos jurídicos, 
português que o consentimento, classificado como elemento essencial do ato jurídico, confunde-se com a manifestação da vontade ${ }^{100}$.

No Brasil, seguiu nesse tocante a posição firmada pelo autor do Código Civil pátrio, José Augusto CESAR, quem em sua obra clássica sobre o tema defende que os atos ou negócios jurídicos - designa-os indistintamente - são declarações de vontade destinadas a constituir, modificar ou extinguir relações jurídicas ${ }^{101}$. Percebe-se que o autor do início do século passado não admite a distinção entre os atos jurídicos nãonegociais e os negócios jurídicos, mas deixa clara sua adesão dentro do campo voluntarista também á teoria da declaração, asseverando que a vontade que não manifestada juridicamente não existe e, portanto, observa para a produção dos efeitos jurídicos perseguidos a concorrência de duas vontades: a de realizar o negócio jurídico e a de fazer a sua pertinente declaração ${ }^{102}$.

Na mesma linha doutrinária seguem João Luiz ALVES ${ }^{103}$, Eduardo ESPINOLA ${ }^{104}$, Carvalho Santos ${ }^{105}$, Luiz da Cunha Gonçalves ${ }^{106}$, Vicente Ráo ${ }^{107}$ e SAN Tiago DANTAS $^{108}$.

de que aqui tratamos. Nos atos em que se não dá manifestação de vontade, não resultam outros direitos e obrigações senão aqueles que as leis expressamente determinam - id., art. 32". Instituições de Direito Civil, Tomo I, São Paulo, Saraiva, 1984, p. 52:

"§99. A manifestação da vontade supõe e ordinariamente confunde-se com o consentimento. Este pode ser expresso ou tácito. Diz-se consentimento expresso, quando é declarado por palavras, ou por escrito, ou por outros sinais não-equívocos, representativos de palavras - L. 38 e 52 , §10, D. de oblig. et act., e tácito, quando alguém pratica fatos, que não admitem outra explicação razoável senão vontade de dar o consentimento a um ato, ou aceitar uma obrigação (quasi contractus); (...)". José Augusto CeSAR, Ensaio sobre os Actos Juridicos, Campinas, Casa Genoud, 1913, pp. 29 a 31:

"Actos ou negocios juridicos são, pois, as declarações de vontade simples ou ligadas a outros factos, as quaes se destinam a constituir, modificar ou extinguir as relações de direito.

Uma notificação promovida pela parte, uma oferta de pagamento são negocios juridicos. Não importa que todos os efeitos desses actos sejam estabelecidos pela lei, porquanto o que põe em movimento a dispozição legal, o que determina a aplicação da norma é um acto da vontade do interessado. Ao inverso a aquizição da propriedade mediante uzucapião não constitue um negocio juridico, pois não deriva de uma declaração de vontade".

José Augusto CESAR, Ensaio sobre os Actos Juridicos, Campinas, Casa Genoud, 1913, p. 46:

"O direito só regula factos externos; a vontade que não se manifesta legalmente não eziste. Para que um acto de volição produza efeitos juridicos, é precizo que se traduza numa expressão externa juridicamente apreciavel. Vontade juridica, é pois, vontade declarada.

Não basta a vontade de realizar o negocio; cumpre que concorra a vontade de fazer a declaração. Aquele que depois de haver deliberado um negocio, comunicasse essa resolução confidencialmente a amigos, não teria emitido uma declaração de vontade juridica. Faltaria nesse cazo a vontade da declaração".

103 Comentando o artigo 82 do então recém editado Código Civil, o Senador da República partícipe no trâmite do diploma legislativo ressalta que a validade do ato jurídico tem seu substrato no consentimento indene de vícios. 
João Luiz Alves, Codigo Civil da Republica dos Estados Unidos do Brasil - Annotado, Rio de Janeiro, F. Briguiet e Cia., 1917, p. 80:

"- As condições essenciaes para a validade do acto juridico, prescriptas neste art., são as mesmas que a doutrina e o Dir. Ant. exigem (N. Consol., art. 223; Dig. Port., I. 219 e 220), subentendendose que o consentimento, não viciado (arts. 86 a 105), fórma o proprio substractum do acto juridico". vol. 1, Bahia, Joaquim Ribeiro \& Co., 1918, p. 227:

"Prescreve o art. 82 que o acto juridico, para ser valido, deve proceder dum agente capaz, ter objecto licito e manifestar-se pela forma prescripta na lei, ou, quando esta não imponha forma especial, por qualquer que não seja prohibida.

Escreve o Prof. Merêa, da Universidade de Coimbra: 'Entre os requisitos da validade do negocio juridico, cumpria mencionar ainda a vontade e sua manifestação. E' a este elemento que respeitam os arts. 85 a 105'.

Tambem Clovis, na 'Theoria Geral do Direito', allude á manifestação de vontade como requisito do acto iuridico.

Se analysarmos a figura do acto iuridico, veremos que para sua constituição é indispensavel se manifeste a vontade no sentido de estabelecer uma relação de direito. Essa vontade só corresponderá aos fins, a que se destina, se proceder duma pessoa legalmente capaz, tiver objecto juridicamente permittido e fôr exteriorizada em forma prescripta ou admittida por lei".

J. M. Carvalho SAntos, Codigo Civil Brasileiro Interpretado - Principalmente sobre o ponto de vista pratico - Parte Geral (arts. 43 - 113), Rio de Janeiro, Calvino Filho, 1934, pp. 264 a 266 :

"Discreminando-se, dentre os elementos do facto juridico, que é o genero, os caracteristicos deste, chega-se naturalmente á definição: 'Acto ou negocio juridico é a declaração de vontade, simples ou ligada a outros factos, a qual se destina a constituir, modificar ou extinguir as relações de direito'. (...)

Para que a vontade manifestada seja efficaz e possa attingir o escopo visado, portanto, faz-se mistér tenha um conteúdo juridico, que é como o thema da relação que se quer constituir, e que, considerado objectivamente, é producto separado da vontade que a determinou e da pessoa que a quer.

(...)

Isso não significa, já ficou dito e convem repetir, que o effeito produzido deva ser inteiramente previsto e corresponda, sem discrepancia, ao pensamento do declarante; tal pensamento basta ser concebido e exposto no sentido juridico que se quer, segundo o conteúdo legal da relação juridica; a vontade se determina, explica-se, dando vida e movimento real ao schema legal da relação juridica, como abstractamente é pensada e descripta pela lei, encarnando-a em si. D'onde, querer um facto é querel-o do mesmo modo e com a mesma força por que a lei p regula (Cfr. CHIRONI e ABELLO, obr. cit., pag. 372; WINDSCHEID, obr. cit., §69; CROME, obr. cit., vol. 1, §86).

Ainda que as consequencias sejam contrarias á vontade subjectiva do agente, o certo é que serão sempre correspondentes á sua intenção pratica, porque quem quer uma relação juridica deve querel-a com aquella efficacia e extensão que tem na lei e com os effeitos que lhe são legalmente attribuidos (CHIRONI e ABELLO, obr. e loc. cits.)".

Ao tratar dos requisitos dos atos jurídicos, o autor enfatiza que a manifestação da vontade não se encontra entre eles, porque ela é, na realidade, pressuposto do ato jurídico, e se encontra presente em cada um dos requisitos enumerados: a capacidade, o objeto e a forma.

J. M. CARVAlho SAntos, Codigo Civil Brasileiro Interpretado - Principalmente sobre o ponto de vista pratico - Parte Geral (arts. 43 - 113), Rio de Janeiro, Calvino Filho, 1934, pp. 266 e 267 :

"Não nos parece que a manifestação da vontade possa ser incluida entre os requisitos, porque ella é mais do que isso: é um presupposto. $O$ acto juridico presuppõe, de facto, a manifestação da vontade, sendo esta, na phrase de PRATES DA FONSECA, o principio vital, verdadeiro substractum do acto juridico. Ennumeral-a com os demais requisitos do acto seria produzir uma classificação imperfeita pois o seu valor não é equivalente ao dos demais: ella está incluida em cada um destes. Para que a manifestação da vontade colha a figura de acto juridico, é preciso que a declaração parta de agente capaz, recaia sobre objecto licito e se produza em forma prescripta ou não defesa em lei. A simples vontade ou resolução não bastam, para que o acto exista: será necessario que essa deliberação se manifeste de modo valido. Mas, justamente para que essa declaração se realize validamente é que se requerem a capacidade, o obiecto licito e a forma. A capacidade é considerada em relação á declaração de vontade. A forma e o objecto tambem o são, 
evidentemente. Ninguem dirá, porém, que a manifestação da vontade esteja, para com os requisitos apontados, na mesma relação de dependencia, ou estes tenham entre si os mesmos caracteristicos de condição, e, que, por conseguinte, a manifestação da vontade vise a perfeição da forma ou do objecto, etc. (Obr. cit. pag. 16)".

"A declaração da vontade é a base de todos os actos jurídicos. Nos contratos ela chama-se mútuo consenso, porque a vontade tem de ser declarada por ambos ou todos os contraentes e convergente, 'in idem placitum consensus'.

Mas, para atingir o fim visado, a declaração de vontade deve ter os requisitos seguintes: $a$ ) ser feita com seriedade; $b$ ) ser consciente; c) ser exteriorizada, e nos contratos, até, dirigida ao outro contraente, e não a diversa pessoa, ainda que aquêle não seja determinado, como sucede, nos casos de notificação pública, por anúncios, circulares, etc., e nos contratos de adesão (transportes nos eléctricos e caminhos de ferro, contratos de fornecimentos de gás, luz, água, etc.)".

Este doutrinador, a despeito de ser de nacionalidade portuguesa, é mencionado dentre os nacionais porque a sua obra citada é dedicada também ao direito brasileiro, como ressalta o próprio autor em seu Prefácio: "É que o nosso Tratado era baseado quase exclusivamente no Código Civil português e obedecia ao respectivo método, ao passo que nêste livro, a doutrina é exposta segundo o método científico e com amplas referências ao direito brasileiro. Quer dizer, sem sacrificarmos os princípios, fazemos um estudo de direito comparado, confrontando, a cada passo, o direito português com o direito brasileiro, isto é, com um direito que, filiado por um lado, na tradição portuguêsa, que remonta às Ordenações Filipinas, por outro lado adquiriu novos predicados, ao contacto com a forte vida americana e com a afinada cultura germânica. Com esta publicação queremos, ainda, provar a nossa constante devoção e a nossa gratidão ao Brasil, ou seja, aos ilustres brasileiros que de várias formas nos honraram e com sincero carinho nos acolheram durante a nossa visita àquele país em 1947".

Vicente RÁo, Ato Jurídico, 2a ed., São Paulo, Max Limonad, 1961, pp. 28 a 30:

"De conformidade com o art. 81 de nosso código civil, 'todo ato lícito que tenha por fim imediato adquirir, resguardar, transferir, modificar, ou extinguir diretos, se denomina ato jurídico'. Semelhante definição, além de indicar de modo analítico e imperfeito os fins do ato jurídico, não alude aos seus requisitos (pressupostos e elementos constitutivos). $\mathrm{O}$ ato jurídico desde logo se distingue dos demais fatos voluntários lícitos pela maior relevância da vontade, isto é, da vontade que visa a alcançar, direta e imediata mente, os efeitos práticos protegidos pela norma e recebe desta o poder de auto-regulamentar os interêsses próprios do agente.

(...)

$\mathrm{O}$ ato jurídico, quer crie, quer modifique, quer extinga direitos, sempre tende, em virtude da autonomia da vontade do agente, a afetar, substancialmente, no sentido de sua disposição, a situação sôbre a qual incide (função dispositiva) e seu conteúdo possui caráter preceptivo (estrutura preceptiva), assim auto-regulamentação de interêsses (SANTORO PASSARELLI: loc. cit.).

Consiste, pois, o ato jurídico na declaração dispositiva e preceptiva da vontade do agente, dirigida direta e imediatamente à consecução dos resultados práticos, individuais e sociais, produzidos pelos efeitos que o ordenamento lhe confere".

Francisco Clementino de SAn Tiago Dantas, Programa de Direito Civil - Aulas proferidas na Faculdade Nacional de Direito [1942-1945] - Parte Geral, $2^{\text {a }}$ ed., Rio de Janeiro, Rio, 1979, pp. 257 a 259:

"(...) Os atos jurídicos são, em primeiro lugar, fatos jurídicos voluntários, lícitos, e dentro desta categoria distinguem-se por consistirem numa declaração da vontade.

A declaração da vontade é, portanto, o primeiro que distingue, o ato jurídico de todos os outros fatos voluntários que com ele se possa assemelhar.

(...)

Quanto à declaração da vontade, dela se deve ter urna representação perfeita, para não se confundir os atos jurídicos com os outros atos voluntários que se usa introduzir na categoria dos atos lícitos de conduta.

Deve-se saber que a vontade tem uma manifestação e que, por conseguinte, nela se pode distinguir dois momentos, o momento da vontade propriamente dita, i. e, da vontade tal qual como ela se apresenta na consciência do agente, e o momento da declaração da vontade, i. e, a expressão que o agente dá ao seu modo de sentir". 
Dentre os doutrinadores brasileiros contemporâneos, além dos já destacados Caio Mário da Silva Pereira, Washington de BARros Monteiro e Silvio Rodrigues, merece ainda menção Carlos Alberto BITTAR, que definindo os negócios jurídicos como fatos jurígenos oriundos de declarações de vontade com escopo de alcançar efeitos jurídicos determinados pelo ordenamento, diferencia-os dos atos jurídicos stricto sensu, estes também modalidade de fatos jurígenos, cujos efeitos, contudo, derivam da ordem jurídica independente do desejo ou até mesmo da previsão dos agentes negociantes ${ }^{109}$. Repisa este autor que o elemento fundamental dos negócios jurídicos é a declaração negocial, entendida como o comportamento humano escudado na autonomia privada ou na autonomia da vontade e direcionado à obtenção dos efeitos preordenados pelo

Além de se filiar à teoria subjetiva, ao comentar o fenômeno da reserva mental ou reticência, o doutrinador também deixa clara sua adesão à teoria da declaração dentro do campo voluntarista. Francisco Clementino de SAN Tiago DanTas, Programa de Direito Civil - Aulas proferidas na Faculdade Nacional de Direito [1942-1945] - Parte Geral, 2a ed., Rio de Janeiro, Rio, 1979, pp. 272 e 273:

"A reserva mental é irrelevante para o direito; não produz conseqüência de espécie alguma. $\mathrm{O}$ ato jurídico é uma declaração da vontade e não a vontade em si mesma, de modo que pouco importa saber o que o indivíduo pensa no seu íntimo; o que importa saber é o que ele declara e se se poderá dar alguma importância à formação mesma dessa vontade quando esta formação se transformar em declaração, pois, como no caso dos vícios, há pouco examinado, se o homem, mentalmente, faz uma reticência às suas próprias palavras, aquilo não chega a interferir na ordem jurídica; aquilo permanece o que os canonistas chamavam - um propositum in mente retentum.

(...)

O propositum in mente retentum é alguma coisa que ainda está fora da ordem jurídica, de modo que pouco importa que ele se forme na mente do agente, pois isto não invalida em nada a sua declaração".

Essa última posição, porém, atualmente deve ser analisada cum granus salis em razão da disposição adotada pelo Código Civil de 2002 no seu artigo 110, asseverando que, de fato, a reserva mental em nada interfere na higidez do negócio jurídico, a menos que o destinatário da declaração reticente tivesse conhecimento dessa sua qualidade. Universitária, 2007, p. 187:

"Dentre os fatos jurígenos humanos encontram-se os negócios jurídicos, ou seja, declarações de vontade dirigidas à obtenção de efeitos preordenados no sistema de direito. São declarações volitivas endereçadas ao alcance de resultados previstos no ordenamento jurídico (como, por exemplo, as de testamentos e de contratos).

Representam fatos voluntários, integrados por uma ou por mais declarações de vontade, às quais confere o ordenamento jurídico efeito a eles concordantes. É que a atuação das partes visa, exatamente, a atingir as conseqüências produzidas; vale dizer, os resultados são desejados pelas partes. Já isso não ocorre com os atos jurídicos stricto sensu, de que se distanciam, pois nestes os efeitos se manifestam mesmo se não previstos ou almejados pelas partes. Inexiste, assim, a vontade de obtenção de efeitos como fator determinante. Operam, pois, esses fenômenos ex voluntate e ex legis, respectivamente (como, verbi gratia, na compra e venda, na doação, na contemplação testamentária, de um lado, e na descoberta de um tesouro, na apreensão ou na ocupação de uma coisa, na construção de um bem, na criação de uma obra intelectual, de outro)". 
direito, ou seja, o nascimento, a conservação, a transformação ou o extermínio de relações jurídicas ${ }^{110}$.

Também cabe destacar na cepa de autores nacionais contemporâneos Álvaro Villaça AZEVEDO, quem inclinando-se para a teoria objetiva do negócio jurídico, esclarece que por meio de sua vontade os agentes se vinculam e fixam normas que vão reger seus próprios interesses, enfatizando que no âmbito da atividade negocial não se verifica tão somente a vontade dos indivíduos, mas também brotam normas para harmonização desses desideratos em negociação ${ }^{111}$.

Ainda no plano nacional contemporâneo, todavia ponderando que as duas doutrinas contrapostas ao definir o negócio jurídico conferem relevo à sua gênese, na medida que o aproximam ou até o equiparam com o ato de vontade, ou à sua função, nesta hipótese tratando-o como preceito normativo concreto cuja validade deriva do ordenamento jurídico, Antônio Junqueira de AZEVEDo propõe uma definição fixada na estrutura do negócio jurídico, permitindo uma visão mais completa do fenômeno ${ }^{112}$. Universitária, 2007, pp. 188 e 189:

"Assim, o elemento nodal da estrutura do negócio jurídico é a declaração negocial, ou conduta qualificada pelo direito para a produção dos efeitos desejados pelos interessados. Constitui a manifestação mais expressiva da autonomia privada, ou da autonomia da vontade, sendo apta a estabelecer, a preservar, a modificar, ou a pôr fim a relações jurídicas, em consonância com a intenção das partes. É comportamento exteriorizador de um conteúdo volitivo, na busca do objetivo visado. (...)".

111 Álvaro Villaça AzEvedo (coord.), Código Civil Comentado - Negócio Jurídico. Atos Jurídicos Lícitos. Atos Ilícitos - Artigos 104 a 188, vol. II, São Paulo, Atlas, 2003, pp. 42 e 43:

"Esclareça-se, inicialmente, que, no negócio jurídico, as partes interessadas, ao manifestarem sua vontade, vinculam-se, estabelecem, por si mesmas, normas regulamentadoras de seus próprios interesses.

Para Emilio Betti, o negócio jurídico é uma autodeterminação dos próprios interesses das partes contratantes, tendo estas ampla liberdade em regular sua conduta por meio de uma declaração (melhor, manifestação) de vontade, que tem força vinculativa.

(...)

No negócio jurídico, não se realiza, pura e simplesmente, uma vontade, mas criam-se normas para harmonização de vontades, que, aparentemente, parecem antagônicas, contraditórias (por exemplo, comprar e vender)".

112 Antônio Junqueira de AzEvEDo, Negócio Jurídico - Existência, Validade e Eficácia, $4^{\mathrm{a}}$ ed., São Paulo, Saraiva, 2007, p. 14:

"Terminando, pois, (...), podemos concluir que as duas concepções do negócio são insuficientes; impõe-se a adoção de uma terceira concepção, que, aproveitando o material já fornecido pelas outras duas, favoreça uma visão completa do negócio jurídico. Esse ideal, a nosso ver, somente pode ser obtido se nos fixarmos na sua estrutura, entendida essa palavra em seu significado comum, de composição, isto é, se nos fixarmos propriamente no que estrutura, ou compõe, o negócio". 
Dessa perspectiva estrutural, o negócio jurídico pode ser definido como categoria ou fato jurídico abstrato, configurando o suporte fático consubstanciado na manifestação de vontade revestida de circunstâncias negociais suficiente a produzir efeitos jurídicos, porque socialmente essa manifestação da vontade, porque revestida das mencionadas circunstâncias negociais, ostenta o condão de produzir efeitos na órbita do direito. Como categoria, então, o negócio jurídico tem como característica primária a declaração de vontade, esta entendida como manifestação de vontade - que atrelada a circunstâncias negociais - é socialmente reconhecida como dirigida à produção de efeitos jurídicos. Ainda como categoria, o negócio jurídico tem como característica secundária a atribuição de efeitos jurídicos pelo ordenamento à declaração de vontade revestida de circunstâncias negociais, porque o direito subsume-se, nesse tocante, ao reconhecimento social já operado ${ }^{113}$.

Já como fato jurídico concreto, o negócio jurídico define-se como a declaração de vontade a qual o ordenamento confere efeitos jurídicos, desde que observados os ditames fixados pela norma jurídica sobre ele incidente. De todo o modo, fato é que quer sob a perspectiva abstrata ou concreta, o negócio jurídico situa-se como derivado do fato jurídico ${ }^{114}$, mas nessa medida se distingue estruturalmente da categoria dos fatos jurídicos estricto sensu, porque nestes não está presente a declaração de vontade em sua

113 Antônio Junqueira de AzEVEDo, Negócio Jurídico - Existência, Validade e Eficácia, 4a ed., São Paulo, Saraiva, 2007, p. 16:

"Como categoria, ele é a hipótese de fato jurídico (às vezes dita 'suporte fático'), que consiste em uma manifestação de vontade cercada de certas circunstâncias (as circunstâncias negociais) que fazem com que socialmente essa manifestação seja vista como dirigida à produção de efeitos jurídicos; negócio jurídico, como categoria, é, pois, a hipótese normativa consistente em declaração de vontade (entendida esta expressão em sentido preciso, e não comum, isto é, entendida como manifestação de vontade, que, pelas suas circunstâncias, é vista socialmente como destinada à produção de efeitos jurídicos). Ser declaração de vontade é a sua característica específica primária. Segue-se daí que o direito, acompanhando a visão social, atribui, à declaração, os efeitos que foram manifestados como queridos, isto é, atribui a ela efeitos constitutivos de direito - e esta é a sua característica específica secundária".

114 Antônio Junqueira de AzEVEDo, Negócio Jurídico - Existência, Validade e Eficácia, 4a ed., São Paulo, Saraiva, 2007, p. 16:

"In concreto, negócio jurídico é todo fato jurídico consistente em declaração de vontade, a que o ordenamento jurídico atribui os efeitos designados como queridos, respeitados os pressupostos de existência, validade e eficácia impostos pela norma jurídica que sobre ele incide.

Visto através do próprio ângulo do direito, estática, ou formalmente, se quiserem, o negócio, in abstrato ou in concreto, coloca-se portanto, antes de mais nada, debaixo da rubrica mais ampla do fato jurídico". 
acepção técnica de ato de vontade revestido de circunstâncias negociais socialmente reconhecido como dirigido à consecução de determinados efeitos jurídicos ${ }^{115}$.

Isso colocado, pode-se dizer que a declaração de vontade significa sob a perspectiva social o que o negócio jurídico significa sob a perspectiva do direito. A declaração de vontade é a hipótese normativa do fato jurídico do qual o negócio jurídico é espécie. Assim, da junção da hipótese legal, com a proteção a ela conferida pelo ordenamento jurídico, que concede os efeitos jurídicos perseguidos às manifestações de vontade revestidas de circunstâncias negociais socialmente reconhecidas como dirigidas ao alcance desses efeitos, tem-se a estrutura do negócio jurídico. "O importante na caracterização do negócio é salientar que, se, em primeiro lugar, ele é um ato cercado de circunstâncias que fazem com que socialmente ele seja visto como destinado a produzir efeitos jurídicos, em segundo lugar, a correspondência, entre os efeitos atribuídos pelo direito (efeitos jurídicos) e os efeitos manifestados como queridos (efeitos manifestados), existe, porque a regra jurídica de atribuição procura seguir a visão social e liga efeitos ao negócio em virtude da existência de manifestação de vontade sobre eles" $^{116}$.

Desse modo, a posição defendida por Antônio Junqueira de Azevedo, embora não hostilize, afasta-se do campo voluntarista, visto que não trata o negócio jurídico como resultado da vontade íntima e psicológica do indivíduo, mas lhe confere contornos socialmente reconhecidos como imbuídos de alcançar determinados efeitos jurídicos, deslocando a sua análise da órbita pessoal para a social ${ }^{117}$.

115 Antônio Junqueira de AzEVEdo, Negócio Jurídico - Existência, Validade e Eficácia, 4ª ed., São Paulo, Saraiva, 2007, pp. 16 e 17:

"Como categoria, por sua previsão normativa tomar em consideração a existência de um fato, que é visto socialmente como ato de vontade (já que ele é declaração de vontade), o negócio jurídico distingue-se claramente, em primeiro lugar, dos fatos jurídicos em sentido estrito. Não se trata, aqui, de verificar quais os fatos que in concreto são, ou não, atos de vontade, mas sim verificar se, pela estrutura normativa, se toma, ou não, em consideração a existência do que socialmente se vê como ato ou manifestação de vontade. Determinados fatos que, na realidade, são atos voluntários poderão entrar no mundo jurídico como fatos em sentido estrito, por a norma jurídica não levar em conta, na sua composição, nem o elemento 'decláração de vontade', nem sequer a simples manifestação de vontade; por exemplo, a morte, para efeitos sucessórios, é fato involuntário (fato jurídico em sentido estrito), quer se esteja diante de morte natural, quer de morte provocada por terceiros, quer, finalmente, se trate de suicídio e, portanto, neste último caso, ela tenha sido, na realidade, ato de vontade". Antônio Junqueira de AzEVEDo, Negócio Jurídico - Existência, Validade e Eficácia, 4ª ed., São Paulo, Saraiva, 2007, p. 19.

117 Antônio Junqueira de AZEVEDo, Negócio Jurídico - Existência, Validade e Eficácia, 4ª ed., São Paulo, Saraiva, 2007, p. 21: 
Por outro lado não acolhe a feição do negócio jurídico como norma concreta, porém aproxima-se da teoria objetiva na medida em que reconhece que os efeitos jurídicos perseguidos resultam da proteção que o ordenamento jurídico confere à declaração de vontade conforme os seus ditames; não são normas, mas são relações jurídicas às quais a ordem jurídica atribui os efeitos jurídicos socialmente reconhecidos como desejados $^{118}$.

Uma distinção relevante também evidenciada pelo mesmo autor diz respeito aos critérios de validade, cuja inobservância enseja a anulabilidade ou nulidade do negócio jurídico, e o critério de licitude, cuja afronta dá azo à indenização. Explica que o negócio jurídico não acolhe entre seus elementos a licitude, sendo essa tão somente uma característica, o que redunda que os negócios jurídicos cuja validade restou por algum motivo comprometida não necessariamente são ilícitos e demandam indenização. Os negócios jurídicos para produzirem os efeitos jurídicos que almejam as partes precisam existir, ser válidos e eficazes, de modo que incorrerão em nulidade se não preencherem os requisitos de validade, ao passo que os atos ilícitos apresentam dois planos, a existência e eficácia, ou seja, verificada a prescrição legal, aplica-se a sanção, no plano civil, por regra, materializada na indenização ${ }^{119}$.

"(...), quer-nos parecer que uma concepção estrutural do negócio jurídico, sem repudiar inteiramente as concepções voluntaristas, dela se afasta, porque não se trata mais de entender por negócio um ato de vontade do agente, mas sim um ato que socialmente é visto como ato de vontade destinado a produzir efeitos jurídicos. A perspectiva muda inteiramente, já que de psicológica passa a social. O negócio não é o que o agente quer, mas sim o que a sociedade vê como a declaração de vontade do agente. Deixa-se, pois, de examinar o negócio através da ótica estreita do seu autor e, alargando-se extraordinariamente o campo de visão, passa-se a fazer o exame pelo prisma social e mais propriamente jurídico".

118 Antônio Junqueira de AZEVEDO, Negócio Jurídico - Existência, Validade e Eficácia, 4ª ed., São Paulo, Saraiva, 2007, p. 21:

"Por outro lado, rejeitada como artificial a idéia do negócio como 'norma jurídica concreta', nem por isso a visão ora apresentada deixa de ser menos objetiva que a das concepções preceptivas. Não ficam, através dela, de forma alguma esquecidos os efeitos que do negócio resultam; esses efeitos, porém, não estão presos, como normas, a outras normas, mas sim, mais simplesmente, são relações jurídicas (em sentido lato) que o ordenamento jurídico, respeitados certos pressupostos (de existência, validade, eficácia), atribui ao negócio, em correspondência com os efeitos manifestados como queridos".

119 Antonio Junqueira de AZEVEDO, (Parecer) O direito como sistema complexo e de $2^{a}$ ordem; sua autonomia. Ato nulo e ato ilícito. Diferença de espírito entre responsabilidade civil e penal. Necessidade de prejuízo para haver direito de indenização na responsabilidade civil, in Estudos e Pareceres de Direito Privado, São Paulo, Saraiva, 2004, pp. 29 e 30:

"10. (...) Todavia, deixando de lado a epidemia processual, é tempo de se voltar ao direito material e, aqui, o que importa é que o critério do lícito é inteiramente diverso do critério do nulo (nulo lato sensu). Nulas são somente as declarações de vontade preceptivas, isto é, aquelas que, no sistema jurídico, são vistas como destinadas diretamente a produzir efeitos jurídicos; somente estas, justamente pelos fins visados por ato de decisão jurídica, têm requisitos previstos para sua 


\section{c) Os Planos da Existência, Validade e Eficácia}

Quando se tem em mente o "fato jurídico lato sensu", definido como o acontecimento sobre o qual incide norma de direito e que gera efeitos na ordem jurídica, para assim caracterizá-lo, há de se proceder à análise em dois planos. No primeiro, da existência, verifica-se se o fato traz consigo suficientes elementos para se dizer que ele realmente existe, tais como: quando ocorreu, em que lugar, como ocorreu, etc. No segundo plano, o da eficácia, será averiguado se sobre o apontado fato realmente incide norma de direito e quais os efeitos que sua ocorrência gerou, gera ou gerará para a ordem jurídica $^{120}$.

Tratando-se do "negócio jurídico", em razão da especificidade de sua caracterização exigir manifestação de vontade, com escopo específico de gerar efeitos jurídicos previstos pelo ordenamento - efeitos desejados pelo agente no momento que declara a vontade, e revestida de circunstâncias negociais que socialmente evidenciam a idéia de que aquela manifestação quer atingir o efeito legal, aparece mais um plano para seu exame, inserto entre o da existência e o da eficácia, o da validade ${ }^{121}$.

regularidade. Ilícitos são os atos reprovados pelo sistema jurídico; de um ato ilícito, como um crime, não se diz ser nulo. Sobre eles, a lei somente prevê a hipótese (fattispecie) e a conseqüência jurídica; portanto, dois planos: existência e eficácia. Já os atos preceptivos, como os negócios jurídicos e os atos negociais administrativos, exigem um cuidado especial do legislador, porque seus efeitos, na ordem normal das coisas, serão os declarados como queridos, isto é, os que constam, por uma decisão, de seu 'texto' ou conteúdo; esses atos, por isso, exigem requisitos de validade. Ou seja, além da existência, é preciso verificar sua regularidade, para que possam, ao final, produzir seus efeitos próprios; portanto, três planos: existência, validade e eficácia (...). $\mathrm{O}$ plano da validade não existe para os atos ilícitos enquanto tais.

11. (...) Do ponto de vista material, porém, insistimos: os casos são completamente diferentes; o nulo diz respeito a ato preceptivo e sua consequêencia é a volta ao statu quo ante, o ilícito é o ato reprovado pelo sistema e sua conseqüência habitual é o pagamento de perdas e danos".

Antônio Junqueira de AzEVEDo, Negócio Jurídico - Existência, Validade e Eficácia, 4ª ed., São Paulo, Saraiva, 2007, pp. 23 e 24:

“(...) O fato jurídico entra no mundo jurídico para que aí produza efeitos jurídicos. Tem ele, portanto, eficácia jurídica. Por isso mesmo, a maioria dos autores define o fato jurídico como o fato que produz efeitos no campo do direito. 'Fatos jurídicos são os acontecimentos em virtude dos quais relações de direito nascem e se extinguem' [Savigny]. Há até mesmo, quem veja nessa eficácia jurídica dos fatos jurídicos a sua essência [Carnelutti]. Em tese, porém, o exame de qualquer fato jurídico deve ser feito em dois panos: primeiramente, é preciso verificar se se reúnem os elementos de fato para que ele exista (plano da existência); depois, suposta a existência, verificar se ele passa a produzir efeitos (plano da eficácia)".

121 Antônio Junqueira de AZEVEDO, Negócio Jurídico - Existência, Validade e Eficácia, 4a ed., São Paulo, Saraiva, 2007, p. 24:

"Sendo o negócio jurídico uma espécie de fato jurídico, também o seu exame pode ser feito nesses dois planos. Entretanto, e essa é a grande peculiaridade do negócio jurídico, sendo ele um caso especial de fato jurídico, já que seus efeitos estão na dependência dos efeitos que foram manifestados como queridos, o direito, para realizar essa atribuição, exige que a declaração tenha uma série de requisitos, ou seja, exige que a declaração seja válida. Eis aí, pois, um plano para 
Para sua plena realização, deve o "negócio jurídico" conter os elementos de existência e observar os requisitos de validade, além de atender aos fatores de eficácia $^{122}$.

A existência do negócio jurídico é atestada pela presença dos elementos que o compõem sob a ótica do direito. Tais elementos, conforme o grau de abstração que se adote, podem ser classificados em gerais, comuns a todo e qualquer negócio jurídico, categoriais, próprios de cada espécie do gênero "negócio jurídico" e, finalmente, os particulares, com sendo aqueles elementos voluntários, insertos no negócio pelas partes, mas que não são imanentes nem aos "negócios jurídicos” em geral, nem a nenhuma de suas categorias específicas ${ }^{123}$.

Em razão de ter o "negócio jurídico" como características específicas a declaração de vontade - manifestação de vontade com intenção de gerar efeitos jurídicos previstos pelo ordenamento - e a anuência do direito no tocante à geração destes efeitos pretendidos, vez que circunstancialmente - circunstâncias negociais declarados, de forma a serem socialmente reputados queridos pelo agente, impõe-selhes o plano da validade, ou seja, a observância de regras jurídicas que lhe impingirão o caráter da regularidade ${ }^{124}$. São os requisitos de validade, em última análise,

exame, peculiar ao negócio jurídico - o plano da validade, a se interpor entre o plano da existência e o plano da eficácia".

122 Antônio Junqueira de AzEVEDo, Negócio Jurídico - Existência, Validade e Eficácia, $4^{\mathrm{a}}$ ed., São Paulo, Saraiva, 2007, p. 30:

"Elementos, requisitos e fatores de eficácia são respectivamente os caracteres de que necessita o negócio jurídico para existir, valer e ser eficaz. (...)”.

123 Antônio Junqueira de AzEVEDo, Negócio Jurídico - Existência, Validade e Eficácia, $4^{\mathrm{a}}$ ed., São Paulo, Saraiva, 2007, pp. 39 e 40:

"Resumindo (...), podemos, pois, dizer que elemento do negócio jurídico é tudo aquilo que lhe dá existência no campo do direito. Classificam-se, conforme o grau de abstração, em elementos gerais, isto é, próprios de todo e qualquer negócio; categoriais, isto é, próprios de cada tipo de negócio; particulares, isto é, existentes, sem serem gerais ou categoriais, em determinado negócio. Os elementos gerais subdividem-se em intrínsecos (ou constitutivos), que são a forma, o objeto e as circunstâncias negociais, e extrínsecos, que são o agente, o lugar e o tempo do negócio. Os categoriais subdividem-se em inderrogáveis (ou essenciais) e derrogáveis (ou naturais); os primeiros definem o tipo de negócio e os segundos apenas defluem de sua natureza, sem serem essenciais à sua estrutura. Os elementos particulares, finalmente, são em número ilimitado, podendo, porém, ser estudados três, a condição, o termo e o encargo, que, por serem mais comuns, estão sistematizados".

124 Antônio Junqueira de AzEVEDO, Negócio Jurídico - Existência, Validade e Eficácia, 4ª ed., São Paulo, Saraiva, 2007, pp. 41 e 42:

"Entende-se perfeitamente que o ordenamento jurídico, uma vez que autoriza a parte a, ou as partes, a emitir declaração de vontade, à qual serão atribuídos efeitos jurídicos de acordo com o que foi manifestado como querido, procure cercar a formação desse especialíssimo fato jurídico de certas garantias, tanto no interesse das próprias partes, quanto no de terceiros e nos de toda a ordem jurídica. Afinal - e, nesse ponto, as análises das definições 'objetivas', 'preceptivas' ou 
qualificações dos elementos de existência que por determinação do ordenamento jurídico devem ser observados para que o "negócio jurídico” já existente seja também válido $^{125}$.

Sob esse aspecto, o Código Civil inicia a disciplina dos "negócios jurídicos" dispondo justamente acerca da sua validade (art. 104) ${ }^{126}$. São assim requisitos dos negócios jurídicos necessários para que sejam reputados válidos pelo ordenamento

'normativistas' do negócio são esclarecedoras -, se a parte ou as partes podem criar direitos, obrigações e outros efeitos jurídicos (relações jurídicas em sentido amplo, ditas erroneamente 'normas jurídicas concretas'), através do negócio jurídico, isto é, formulando declaração de vontade, essa verdadeira fonte jurídica não pode entrar a funcionar, dentro do ordenamento como um todo, sem qualquer regulamentação, sob pena de ser total a anarquia; há de se proibir a declaração contrária às normas superiores, há de se cercar de segurança certas declarações que interessam a todos. Se, sob outro ângulo, se permite à vontade humana fixar, em larga escala, o conteúdo da declaração - e aqui são as definições 'voluntaristas' que muito revelam -, e se os efeitos são imputados à declaração segundo o seu conteúdo, é evidente que se há de tentar evitar que ocorram declarações decorrentes de vontades débeis, ou não correspondentes à exata consciência da realidade, ou provenientes de violência imposta sobre a pessoa que a emitiu etc. Pois bem, o direito, ao estabelecer as exigências, para que o negócio entre no mundo jurídico com formação inteiramente regular, está determinando os requisitos de sua validade.

A validade é, pois, a qualidade que o negócio jurídico, deve ter ao entrar no mundo jurídico, consistente em estar de acordo com as regras jurídicas ('ser regular'). Validade é, como o sufixo da palavra indica, qualidade de um negócio existente. 'Válido' é adjetivo com que se qualifica o negócio jurídico formado de acordo com as regras jurídicas".

Antônio Junqueira de AzEVEDo, Negócio Jurídico - Existência, Validade e Eficácia, 4ª ed., São Paulo, Saraiva, 2007, pp. 42 e 43:

"Por isso mesmo, se o negócio jurídico é declaração de vontade e se os elementos gerais intrínsecos, ou constitutivos, são essa mesma declaração tresdobrada em objeto, forma e circunstâncias negociais, e se os requisitos são qualidades dos elementos, temos que: a declaração de vontade, tomada primeiramente como um todo, deverá ser: a) resultante de um processo volitivo; b) querida com plena consciência da realidade; c) escolhida com liberdade; d) deliberada sem ma fé (se não for assim, o negócio poderá ser nulo, por exemplo, no primeiro caso, por coação absoluta, ou falta de seriedade; anulável por erro ou dolo, no segundo; por coação relativa, no terceiro; e por simulação, no quarto). O objeto deverá ser lícito, possível, determinado ou determinável; e a forma, ou será livre, porque a lei nenhum requisito nela exige, ou deverá ser conforme a prescrição legal. Quanto às circunstâncias negociais, não têm requisitos exclusivamente seus, já que elas são o elemento caracterizador da essência do próprio negócio, são aquele quid que qualifica uma manifestação, transformando-a em declaração.

Quanto aos elementos gerais extrínsecos, temos que: a) o agente deverá ser capaz e, em geral, legitimado para o negócio; b) o tempo, se o ordenamento jurídico impuser que o negócio se faça em um determinado momento, quer essa determinação seja em termos absolutos, quer seja em termos relativos (isto é, por relação a outro ato ou fato), deverá ser o tempo útil; e c) o lugar, se, excepcionalmente, tiver algum requisito, há de ser o lugar apropriado".

$\mathrm{O}$ autor prossegue na análise no tocante aos requisitos dos elementos categoriais e particulares, porém, tem-se por suficiente a análise dos requisitos dos elementos gerais intrínsecos e extrínsecos. Código Civil:

“Art. 104 - A validade do negócio jurídico requer:

I - agente capaz;

II - objeto lícito, possível, determinado ou determinável;

III - forma prescrita ou não defesa em lei”. 
jurídico o agente capaz, o objeto lícito, possível, determinado ou determinável e a observância da forma prescrita ou não vedada pela lei ${ }^{127}$.

Nota-se que com relação à tormentosa problemática da indagação da causa dos "negócios jurídicos", entendida esta como a razão jurídica da declaração da vontade, ou seja, a finalidade econômica ou social determinante do negócio, que não se confunde com os seus meros motivos, visto que podem ser estes até mesmo ilícitos, mantendo-se indene o ato celebrado, sendo que o mesmo não ocorre quando de trata de causa ilícita $^{128}$, o direito brasileiro filiou-se à concepção não anticausalista, reputando irrelevante esta investigação, mas apenas dela tratando de forma circunstancial ${ }^{129}$.

Caio Mário da Silva PEREIRA, Instituições de Direito Civil - Introdução ao Direito Civil - Teoria Geral do Direito Civil, vol. I, $23^{\mathrm{a}}$ ed. atualizada por Maria Celina Bodin de Moraes, Rio de Janeiro, Forense, 2010, p. 415:

"Se, (...), o negócio jurídico é uma emissão volitiva dirigida a um determinado fím, existe destinado a produzir seus efeitos. Mas estes não se lhes seguem, e aquela se frustra, se o ordenamento jurídico the denega as conseqüências naturais, atingindo-se então um resultado negativo, caso em que se tacha o negócio jurídico de inválido (...). Para que receba do ordenamento jurídico conhecimento pleno, e produza todos os efeitos, é de mister que o negócio jurídico revista certos requisitos que dizem respeito à pessoa do agente, ao objeto da relação e à forma da emissão de vontade. É o que deflui do art. 104 do Código Civil, segundo o qual a validade do negócio requer agente capaz, objeto lícito, possível, determinado ou determinável, e forma adequada". Caio Mário da Silva PereIRA, Instituições de Direito Civil - Introdução ao Direito Civil - Teoria Geral do Direito Civil, vol. I, $23^{\mathrm{a}}$ ed. atualizada por Maria Celina Bodin de Moraes, Rio de Janeiro, Forense, 2010, p. 433:

"Na caracterização da causa, portanto, é preciso expurgá-la do que sejam meros motivos, e isolar o que constitui a razão jurídica do fenômeno, para abandonar aqueles e atentar nesta. Na causa há, pois, um fim econômico ou social reconhecido e garantido pelo direito, uma finalidade objetiva e determinante do negócio que o agente busca além da realização do ato em si mesmo. Como este fim se vincula ao elemento psíquico motivador da declaração de vontade, pode ser caracterizado, sob outro aspecto, como a intenção dirigida no sentido de realizar a consequiência jurídica do negócio. Mas sempre haverá distinguir da causa a motivação, pois que esta, mesmo ilícita, não chega a afetar o ato, desde que àquela não se possa irrogar a mesma falha.

Assim caracterizada, a causa tanto pode ser investigada nos negócios jurídicos bilaterais, e neles o é bilateralmente (na compra e venda, a causa da declaração de vontade do vendedor é trocar a coisa pela prestação pecuniária do comprador e, vice-versa, a deste receber do vendedor a coisa), quanto o pode ser unilateralmente, nos negócios jurídicos unilaterais (no testamento a causa da declaração de vontade do testador é a liberalidade ou o benefício para o legatário)".

129 Caio Mário da Silva PereIRA, Instituições de Direito Civil - Introdução ao Direito Civil - Teoria Geral do Direito Civil, vol. I, $23^{\mathrm{a}}$ ed. atualizada por Maria Celina Bodin de Moraes, Rio de Janeiro, Forense, 2010, p. 435:

"O direito brasileiro, nesta discussão sem fim, tomou partido na fileira anticausalista, e o Código Civil não cogitou da sistemática da causa, parecendo ao legislador desnecessária a sua indagação, na integração dos requisitos dos negócios jurídicos, in genere, preferindo cogitar dela em circunstâncias especiais, como, por exemplo, na teoria do contrato aleatório, quando autoriza a sua anulação sob fundamento de que a parte não ignorava o desaparecimento da álea (art. 461); na exceptio inadimpleti contractus (art. 476); na estrutura da repetição do indébito (arts. 876 e segs.); na nomeação do herdeiro ou legatário, que se pode fazer por certo motivo (art. 1.897) etc. Não considerou, porém, a causa como requisito do negócio jurídico. Assim é que, se no direito francês o ato é inválido por iliceidade de causa, no direito brasileiro a mesma invalidade o atinge por iliceidade do objeto. Assim procedendo, o nosso direito procurou simplificar a solução das questões, instilando maior segurança nos negócios, e recusando que, a pretexto de investigar a 
Washington de BARros MonTEIRO, por seu turno, pondera com espeque no escólio de H. CAPITANT que a causa dos "negócios jurídicos" na realidade se confunde com o objetivo perseguido e, portanto, com o seu objeto ${ }^{130}$.

Por fim, tem-se o plano da eficácia, no âmbito do qual se verifica se o "negócio jurídico" existente e válido está apto a gerar os efeitos jurídicos desejados pela vontade declarada ${ }^{131}$. Por regra, os negócios jurídicos têm eficácia imediata, no entanto, há hipóteses em que dependem de fatores extrínsecos ${ }^{132}$ ao negócio para que tenha início a produção de seus efeitos jurídicos ${ }^{133}$.

Percebe-se, então, que o Código Civil ao tratar do "negócio jurídico" cuidou, preponderantemente, da disciplina da sua validade e dos atinentes requisitos. Merece,

causa, alguém se exacerbe na busca dos motivos. Nesse particular, a redação dada ao atual art. 140 veio corrigir o antigo art. 90 do Código de 1916, substituindo-se o termo errôneo - "causa" - pelo correto, ao dizer que o falso motivo só vicia o ato for expresso como sua razão determinante.

(...)

O Código de 2002 manteve-se na mesma linha de orientação não causalista bem como perfilhou aquela indicação, por nós projetada. Nele predominou o caráter não causalista em princípio, havendo mantido entre os requisitos de validade do negócio jurídico os que para nós já são tradicionais, a saber - capacidade das partes, liceidade do objeto e forma. A falta de causa vai fundamentar a ação de enriquecimento, ainda que venha a faltar após a celebração do ato, como prevêem os arts. 884 e $885 "$ ".

130 Curso de Direito Civil - Parte Geral, vol. 1, 42 ed. atualizada por Ana Cristina de Barros Monteiro França Pinto, São Paulo, Saraiva, 2010, p. 223:

"O Código não se referiu à causa, isto é, ao fim visado pelo agente. Mas, como esclarece CAPITANT, causa é parte integrante do ato de vontade, confunde-se com o próprio escopo do ato. Assim, quando se diz que a causa ilícita vicia o ato jurídico, é porque o próprio objeto dele é ilícito".

131 Antônio Junqueira de AzEVEDo, Negócio Jurídico - Existência, Validade e Eficácia, $4^{\mathrm{a}}$ ed., São Paulo, Saraiva, 2007, p. 49:

"O terceiro e último plano em que a mente humana deve projetar o negócio jurídico para examinálo é o plano da eficácia. Nesse plano, não se trata, naturalmente, de toda e qualquer possível eficácia, prática do negócio, mas sim, tão-só, da sua eficácia jurídica e, especialmente, da sua eficácia própria ou típica, isto é, da eficácia referente aos efeitos manifestados como queridos. (...)".

132 Antônio Junqueira de AzEVEDO, Negócio Jurídico - Existência, Validade e Eficácia, 4a ed., São Paulo, Saraiva, 2007, p. 55:

"De fato, muitos negócios, para a produção de seus efeitos, necessitam de fatores de eficácia, entendida a palavra fatores como algo extrínseco ao negócio, algo que dele não participa, que não o integra, mas contribui para a obtenção do resultado visado".

133 Antônio Junqueira de AZEVEDO, Negócio Jurídico - Existência, Validade e Eficácia, 4a ed., São Paulo, Saraiva, 2007, p. 60:

"Cumpre, finalmente, para termos um quadro completo da questão da eficácia, não perder de vista que, ao falarmos de fatores de eficácia, estamos nos referindo ao início da produção de efeitos; esses fatores de eficácia são, pois, em suas três espécies, fatores de atribuição de eficácia (eficácia em geral, eficácia diretamente visada e eficácia mais extensa). Naturalmente, poderá ocorrer que, uma vez existindo, valendo e produzindo efeitos, o negócio venha, depois, por causa superveniente, a se tornar ineficaz. Haverá, então, ineficácia superveniente, isto é, resolução do negócio. (...)". 
porém, destaque, a presença do "princípio da conservação"134, notadamente nos arts. $170^{135}, 172^{136}$ e $184^{137}$, nos quais se verifica no legislador claro desiderato de aproveitar e conservar o máximo que for possível do "negócio jurídico", seja no plano da existência, da validade ou da eficácia, demonstrando o senso de utilidade e importância para o comércio jurídico reputados ao negócio pela lei civil brasileira.

\section{d) Interpretação do Negócio Jurídico}

A interpretação do "negócio jurídico" se funda no estabelecimento do exato conteúdo da declaração volitiva emanada do agente, valendo-se mais de regras empíricas do que propriamente de princípios com solidez científica ${ }^{138}$.

134 Antônio Junqueira de AzEVEDo, Negócio Jurídico - Existência, Validade e Eficácia, 4a ed., São Paulo, Saraiva, 2007, pp. 66 e 67:

"Tanto dentro de cada plano quanto nas relações entre um plano e outro há um princípio fundamental que domina toda a matéria da inexistência, invalidade e ineficácia; queremos referirnos ao princípio da conservação. Por ele, tanto o legislador quanto o intérprete, o primeiro, na criação das normas jurídicas sobre os diversos negócios, e o segundo, na aplicação dessas normas, dêem procurar conservar, em qualquer um dos três planos - existência, validade e eficácia -, o máximo possível do negócio jurídico realizado pelo agente.

O princípio da conservação consiste, pois, em se procurar salvar tudo que é possível num negócio jurídico concreto, tanto no plano da existência, quanto da validade, quanto da eficácia. Seu fundamento prende-se à própria razão de ser do negócio jurídico; sendo este uma espécie de fato jurídico, de tipo peculiar, isto é, uma declaração de vontade (manifestação de vontade a que o ordenamento jurídico imputa os efeitos manifestados como queridos), é evidente que, para o sistema jurídico, a autonomia da vontade produzindo auto-regramentos de vontade, isto é, a declaração produzindo efeitos, representa algo de juridicamente útil. A utilidade de cada negócio poderá ser econômica ou social, mas a verdade é que, a partir do momento em que o ordenamento jurídico admite a categoria negócio jurídico, sua utilidade passa a ser jurídica, visto vez que somente em cada negócio concreto é que adquire existência a categoria negócio jurídico. Não fosse assim e esta permaneceria sendo sempre algo abstrato e irrealizado. Obviamente, não foi para isso que o ordenamento jurídico a criou. O princípio da conservação, portanto, é a conseqüência necessária do fato de o ordenamento jurídico, ao admitir a categoria negócio jurídico, estar implicitamente reconhecendo a utilidade de cada negócio jurídico concreto". Código Civil:

“Art. 170 - Se, porém, o negócio jurídico nulo contiver os requisitos de outro, subsistirá este quando o fim a que visavam as partes permitir supor que o teriam querido, se houvessem previsto a nulidade".

"Art. 172 - O negócio anulável pode ser confirmado pelas partes, salvo direito de terceiro". Código Civil:

“Art. 184 - Respeitada a intenção das partes, a invalidade parcial de um negócio jurídico não o prejudicará na parte válida, se esta for separável; a invalidade da obrigação principal implica a das obrigações acessórias, mas a destas não induz a da obrigação principal”.

138 Caio Mário da Silva PereIRA, Instituições de Direito Civil - Introdução ao Direito Civil - Teoria Geral do Direito Civil, vol. I, 23ª ed. atualizada por Maria Celina Bodin de Moraes, Rio de Janeiro, Forense, 2010, p. 428:

“(...) - A interpretação do negócio jurídico vai, então, situar-se no campo da fixação do conteúdo da declaração de vontade, e, para isto, regras empíricas, mais de lógica prática, do que de normação legal, se vêm repetindo nos autores e até nas leis, com o grave inconveniente de importar 
Nesse ponto, o velho Código de 1916 foi mais sóbrio, limitando-se a um dispositivo, o seu art. 85 ${ }^{139}$, mais tarde repetido pelo Código de 2002 (art. 112) ${ }^{140}$, consagrando o princípio pelo qual não deve o exegeta se prender à interpretação gramatical, mas tentar buscar os efeitos pretendidos pelo agente ao declarar a sua vontade, desprezando o formalismo exacerbado e privilegiando a real intenção do declarante $^{141}$. Por esse preceito, mesmo diante da clara dificuldade de investigação do elemento íntimo da vontade, deve o intérprete libertar-se da literalidade e recuperar a intenção das partes, bem como os seus objetivos econômicos e sociais ${ }^{142}$.

Já o Estatuto de 2002 foi pródigo em estabelecer regras de hermenêutica dos "negócios jurídicos". Uma novidade foi a previsão normativa da reserva mental, que disciplina a hipótese em que o agente declara a vontade, porém faz a ressalva íntima de que não deseja a celebração do negócio. Nessa situação, fixou o art. $110^{143}$ que o

o seu manuseio na utilização de princípios que não oferecem segura solidez científica, e, de outro lado, prestar-se a um desvirtuamento do conteúdo material do negócio jurídico. (...)”. Código Civil de 1916:

"Art. 85 - Nas declarações de vontade se atenderá mais à sua intenção que ao sentido literal da linguagem".

140 Código Civil:

"Art. 112 - Nas declarações de vontade se atenderá mais à intenção nelas consubstanciada do que ao sentido literal da linguagem".

141 Caio Mário da Silva PereIRA, Instituições de Direito Civil - Introdução ao Direito Civil - Teoria Geral do Direito Civil, vol. I, $23^{\mathrm{a}}$ ed. atualizada por Maria Celina Bodin de Moraes, Rio de Janeiro, Forense, 2010, pp. 428 e 429:

"De quantos princípios se possam encontrar repetidos na prática judiciária, o Código Civil de 1916 cuidou de isolar um, que permanece no Código de 2002. (...) O princípio geral a que nos estamos referindo é o do art. 112, repetição quase literal do art. 85 do Código Civil de 1916, o qual estabelece que nas declarações de vontade se atenderá mais à sua intenção do que ao sentido literal da linguagem, e neste passo aproxima-se do direito alemão, que institui regra semelhante no § 133 do BGB. Aqui se reportou o legislador à velha parêmia "potentior est quam vox mens dicentis", e no entender de Clóvis Beviláqua adotou a regra hermenêutica, considerando-a como a própria integração do negócio jurídico, já que a essência deste é a manifestação da vontade. (...)

O princípio traduz, de plano, a repulsa do legislador ao exorcismo da forma, do ritual, do formalismo sem entranhas. $\mathrm{O}$ intérprete do negócio jurídico não pode ficar adstrito à expressão gramatical, e seu trabalho hermenêutico não consistirá apenas no exame filológico do teor lingüístico da declaração de vontade. Este é o ponto nuclear do negócio jurídico, e cumpre, então, inquirir onde efetivamente se situa".

142 Washington de BARros MonTEIRO, Curso de Direito Civil - Parte Geral, vol. 1, 42 a ed. atualizada por Ana Cristina de Barros Monteiro França Pinto, São Paulo, Saraiva, 2010, p. 229:

"Cuida-se inquestionavelmente de preceito salutar, impregnado de profunda sabedoria. Declaração que não corresponda ao preciso intento das partes é corpo sem alma. Deve ser arredado, portanto, entendimento que se apegue tão-somente à literalidade da estipulação, quantum verba sonant, com total desprezo da rigorosa intenção dos interessados e dos fins econômicos que os aproximaram.

Mas nem sempre é fácil a pesquisa desse elemento íntimo e espiritual que movimenta as partes, levando-as à celebração do ato jurídico. Trata-se de investigação que requer ponderação e equilíbrio, ao lado de perfeito conhecimento da vida, na infinidade de suas manifestações". 
"negócio jurídico" é válido desde que a outra parte não tenha conhecimento da reserva $^{144}$. Na circunstância da reserva mental, a declaração de vontade se afasta da vontade real do agente, mas a lei protege o destinatário que disso não tem conhecimento para que ele não fique ao absoluto alvedrio do íntimo desejo do declarante, quem resta impedido de invocar a reticência para invalidar o "negócio jurídico" que celebrou, caso a outra parte tenha tomado por hígida a declaração ${ }^{145}$.

A disposição do art. $111^{146}$ veio disciplinar a interpretação do silêncio, que por regra significa a ausência de declaração de vontade, mas em circunstâncias específicas, quando os usos e costumes permitirem e a declaração expressa for desnecessária, pode ser levado à condição de anuência ${ }^{147},{ }^{148}$.

"Art. 110 - A manifestação de vontade subsiste ainda que o seu autor haja feito a reserva mental de não querer o que manifestou, salvo se dela o destinatário tinha conhecimento". Geral do Direito Civil, vol. I, $23^{\mathrm{a}}$ ed. atualizada por Maria Celina Bodin de Moraes, Rio de Janeiro, Forense, 2010, p. 429:

"A reserva mental, ou reticência, ocorre quando o agente faz a ressalva de não querer o negócio que é objeto da declaração. A regra é que, se a reserva é comunicada à outra parte, é válida; mas, se a pessoa a quem o negócio se dirige a ignora, não pode ter o efeito de anular a declaração, prevalecendo então o negócio jurídico, como se reserva nenhuma existisse. O Código de 1916 não cogitara do assunto, que foi inserido, sob forma de preceito, no Anteprojeto de Código de Obrigações, como já antes o Código Civil alemão o havia feito (§ 116). (...)”.

145 Washington de BARros MonTEIRo, Curso de Direito Civil-Parte Geral, vol. 1, 42 ${ }^{\mathrm{a}}$ ed. atualizada por Ana Cristina de Barros Monteiro França Pinto, São Paulo, Saraiva, 2010, p. 224:

"O art. 110 trouxe inovação ao assunto dispondo que a manifestação de vontade subsiste ainda que o agente haja feito a reserva mental de não querer o que manifestou, salvo se dela o destinatário tinha conhecimento.

$\mathrm{Na}$ reserva mental ou reticência, a vontade declarada não coincide com a vontade real, com o intuito de enganar a outra parte. Diante do descompasso entre a vontade real e a declarada, o destinatário pode encontrar-se em uma de duas situações: tem conhecimento dessa divergência e está excluída a eficácia do negócio jurídico; ele ignora-a, e o negócio jurídico produz todos os seus efeitos.

Também caracteriza reserva mental a declaração de vontade emitida por brincadeira: se a outra parte sabia da pilhéria, não produz efeitos jurídicos; se levou a sério o negócio jurídico, este tem plena eficácia. E não pode ser invocada pelo próprio declarante para anular negócio jurídico que realizou".

146 Código Civil:

"Art. 111 - O silêncio importa anuência, quando as circunstâncias ou os usos o autorizarem, e não for necessária a declaração de vontade expressa".

147 Caio Mário da Silva PEREIRA, Instituições de Direito Civil - Introdução ao Direito Civil - Teoria Geral do Direito Civil, vol. I, $23^{\mathrm{a}}$ ed. atualizada por Maria Celina Bodin de Moraes, Rio de Janeiro, Forense, 2010, pp. 413 e 414:

"Neste passo, cabe indagar se o silêncio pode ser compreendido como manifestação de vontade, e, pois, gerador de ato negocial. E a resposta é afirmativa. Normalmente, o silêncio é nada, e significa a abstenção de pronunciamento da pessoa em face de uma solicitação ambiente. Por via de regra, o silêncio é a ausência de manifestação de vontade, e, como tal, não produz efeitos. Mas, em determinadas circunstâncias, pode significar uma atitude ou um comportamento, e, conseqüentemente, produzir efeitos jurídicos. Neste caso, deverá ser interpretado como anuência à declaração de vontade. Não se lhe pode atribuir efeito de uma declaração volitiva, pelo simples 
$\mathrm{O}$ art. $113^{149}$ consagrou o princípio da boa-fé objetiva, introduzindo o dever de que os "negócios jurídicos" se interpretem levando em consideração a boa-fé das partes, bem como os usos e costumes do lugar da sua realização ${ }^{150}$. Em linhas muito gerais, a boa-fé traduz os deveres de lealdade, correção, informação e transparência entre as partes $^{151}$. O preceito veio em absoluta consonância com outras disposições do Código civil de 2002 e da velha Lei de Introdução ao Código Civil ${ }^{152}$.

fato de nada declarar a pessoa. (...) O direito romano já se referia ao assunto ao enunciar qui tacet consentire videtur, si loqui debuisset et potuisset ("quem cala parece consentir, se devesse ou pudesse falar"). Com efeito, há situações em que a pessoa não pode ou não deve falar, como no caso de sigilo profissional ou dever de consciência. Ou, ainda, quando o negócio jurídico tenha de resultar de manifestação expressa do querer do agente. Em tais situações, o silêncio não induz anuência, porém somente quando a lei o estabeleça, ou o autorizarem os usos ou circunstâncias do caso. (...).

148 Washington de BArros MonteIro, Curso de Direito Civil-Parte Geral, vol. 1, 42 ${ }^{\mathrm{a}}$ ed. atualizada por Ana Cristina de Barros Monteiro França Pinto, São Paulo, Saraiva, 2010, p. 231:

"O silêncio importa anuência quando as circunstâncias ou os usos o autorizarem, e não for necessária a declaração de vontade expressa (art. 111 do Cód. Civil de 2002). Efetivamente, há casos em que o silêncio implica anuência de quem deve expedir a manifestação de vontade. (...)". Código Civil:

"Art. 113. Os negócios jurídicos devem ser interpretados conforme a boa-fé e os usos do lugar de sua celebração".

150 Caio Mário da Silva PereIRA, Instituições de Direito Civil - Introdução ao Direito Civil - Teoria Geral do Direito Civil, vol. I, 23 ${ }^{\text {a }}$ ed. atualizada por Maria Celina Bodin de Moraes, Rio de Janeiro, Forense, 2010, p. 430:

"Sem as demasias do Código Napoleão, Código Civil de 2002 não foi tão avaro como o Código de 1916. Além de explicitar a possibilidade de o silêncio traduzir manifestação de vontade (art. 111), consignou, ainda, a regra Treu und Glauben do BGB, ao mandar que a declaração de vontade se interprete de acordo com a boa-fé e os usos dos negócios (art. 113). O Código Civil alemão é unanimemente elogiado quando consagra este princípio ( $\$ 157)$. Os negócios jurídicos devem ser inspirados na boa-fé, na lealdade e na confiança das partes. Na sua execução devem guardar-lhes fidelidade, e, portanto, assim devem ser interpretados. A regra não é nova no direito pátrio, pois que o Código Comercial de 1850 já a consagrava no art. $131,1^{\circ}$, como regra de hermenêutica nos negócios empresariais. Cumpre, pois, ao intérprete da vontade negocial dar ênfase ao respeito ao princípio da boa-fé, como elemento ético da relação".

151 Caio Mário da Silva PereIRA, Instituições de Direito Civil - Introdução ao Direito Civil - Teoria Geral do Direito Civil, vol. I, $23^{\mathrm{a}}$ ed. atualizada por Maria Celina Bodin de Moraes, Rio de Janeiro, Forense, 2010, p. 431:

"A boa-fé, em sua concepção objetiva, como conduta ética entre as partes que negociam, impõe correção e lealdade. Nesse contexto, ela sobrepaira como "princípio orientador da interpretação". No entanto, o princípio da boa-fé objetiva, segundo a moderna doutrina, também possui o condão de criar deveres jurídicos anexos, como deveres de correção, cuidado, cooperação, sigilo, prestação de contas, e mesmo de limitação do exercício de direitos subjetivos, como ocorre nas proibições de venire contra factum proprium, do inciviliter agere e na invocação do tu quoque, (...). Relevante será, também, invocar os usos vigentes no lugar da celebração do negócio jurídico, no pressuposto de que as partes, de maneira geral, a eles se submetem implicitamente. Na divergência ao tempo da execução, invocá-los é bom adminículo hermenêutico".

152 Washington de BArros MonteIro, Curso de Direito Civil-Parte Geral, vol. 1, 42 a ed. atualizada por Ana Cristina de Barros Monteiro França Pinto, São Paulo, Saraiva, 2010, p. 229:

“Aduz o art. 113, fornecendo outra importante regra de interpretação dos negócios jurídicos: “Os negócios Jurídicos devem ser interpretados conforme a boa-fé e os usos do lugar de sua celebração". Esse dispositivo afina-se com a Lei de Introdução ao Código Civil: "Na aplicação da lei, o juiz atenderá aos fins sociais a que ela se dirige e às exigências do bem comum". 
Finalmente, o art. $114^{153}$ não trouxe propriamente uma novidade, mas transportou para a Parte Geral e estendeu a todos os "negócios jurídicos" a disposição do art. $1.090^{154}$ do velho Código Beviláqua, ampliando a regra de forma também a abarcar também as hipóteses de renúncia de direito ${ }^{155}$. Trata-se de regra de intuitiva compreensão, visto que versa acerca de "negócios jurídicos" que em geral trazem benefício tão somente a uma parte e desse modo devem interpretados de modo restritivo $^{156}$.

Não foi outro o pensamento do legislador de 2002 ao dispor, no art. 2.035, parágrafo único, nas disposições finais e transitórias, que nenhuma convenção prevalecerá se contrariar preceitos de ordem pública, tais como os estabelecidos pelo Código para assegurar a função social da propriedade".

153 Código Civil:

"Art. 114 - Os negócios jurídicos benéficos e a renúncia interpretam-se estritamente".

154 Código Civil de 1916:

"Art. 1.090 - Os contratos benéficos interpretar-se-ão estritamente".

155 Caio Mário da Silva PereiRA, Instituições de Direito Civil - Introdução ao Direito Civil - Teoria Geral do Direito Civil, vol. I, $23^{\text {a }}$ ed. atualizada por Maria Celina Bodin de Moraes, Rio de Janeiro, Forense, 2010, p. 431:

"O Código transpôs para a Parte Geral (art. 114) o disposto no art. 1.090 do Código Civil de 1916, que mandava que se interpretassem estritamente os contratos benéficos. Generalizou para todo negócio jurídico o princípio que recomenda não dar interpretação ampliativa a quaisquer atos liberais. E, com a mesma orientação, abrangeu na mesma regra a renúncia".

156 Washington de BARros Monteiro, Curso de Direito Civil - Parte Geral, vol. 1, 42 a ed. atualizada por Ana Cristina de Barros Monteiro França Pinto, São Paulo, Saraiva, 2010, p. 229:

"O art. 114 contém regra de intuitiva compreensão: os negócios benéficos e a renúncia interpretam-se restritivamente. Realmente, em geral trazendo vantagens para apenas uma das partes, é natural que sua interpretação se faça restritivamente, de modo a não incluir mais do que realmente queria ou podia dispor quem por essa forma se manifestou". 


\section{CAPÍTULO II - O NEGÓCIO JURÍDICO NO DIREITO ROMANO}

Sob inspiração jusnaturalista, Antonio Junqueira de AZEVEDO assegura que o negócio jurídico é um fato social, um comportamento humano verificado em qualquer sociedade, primitiva ou atual, tal qual a linguagem ou o convívio humano, e remonta à pré-história, de modo que não se possa confundir o momento no qual se formulou o seu conceito com o instante a partir do qual se pôde constatar o fenômeno ${ }^{157}$.

Prossegue lembrando que já na Lei das XII Tábuas havia previsão de três modalidades de negócios jurídicos celebrados por meio da antiga fórmula gestum per aes et libram: o nexum, a mancipatio e o testamentum. E dentre os não abarcados na mencionada fórmula solene do direito romano arcaico, cita também o testamento comicial, derivado do direito público, e a sponsio, esta inicialmente de índole religiosa, mas que posteriormente evoluiu para a stipulatio, quando adquire o caráter laico no âmbito do ius gentium ${ }^{158}$.

A partir de então, na esteira do desenvolvimento do direito dos contratos, as formas negociais se expandem, aparecendo além das antigas fórmulas per aes et libram, Pareceres de Direito Privado, São Paulo, Saraiva, 2004, p. 44:

"Dito isso, voltamos a afirmar: 'negócio jurídico' é um conceito de sempre; o povo, qualquer povo, sempre tem uma idéia clara ainda que confusa do negócio jurídico. O negócio jurídico existe desde a pré-história. É ele um modo de comportamento humano, uma forma - a jurídica - de os homens se relacionarem, como acontece com a linguagem e a convivência social. Não há sociedade sem negócio jurídico. O negócio jurídico é um fato social, no sentido preciso, de criação coletiva. As sociedades primitivas, quer as que existiram quer as que persistem ainda hoje à margem da civilização, apresentam na vida social determinados modelos de comportamento, revelados por observadores inteiramente alheios ao direito e que são atitudes jurídicas: são negócios jurídicos. Dizer que o negócio jurídico 'surgiu' nos séculos XVIII e XIX seria o mesmo que dizer que, antes de Newton, não existiam as leis da gravitação universal e ninguém sabia que os corpos caíam. É confundir o momento da formulação do conceito com o próprio conceito".

Antonio Junqueira de AZEVEDo, Ciência do Direito, Negócio Jurídico e Ideologia, in Estudos e Pareceres de Direito Privado, São Paulo, Saraiva, 2004, p. 45:

"Na Lei das XII Tábuas (T.VI,1 e T.V,3), encontramos aparentemente três tipos de negócios jurídicos, o nexum, a mancipatio e o testamentum; na verdade, porém, todos eram realizados sob uma única forma, a de negócio feito com o bronze e a balança (gestum per aes et libram). (...).

Como possíveis negócios jurídicos que, nos primeiros tempos, não eram feitos per aes et libram, haveria que lembrar, ainda, além do testamento comicial, a sponsio. O primeiro, como se percebe (...), era antes lex publica; já a sponsio era antes ato religioso. Somente bem mais tarde, depois de transformada em stipulatio, ato laico e de ius gentium, é que perderia seu caráter sacral". 
as modalidades contratuais verbais, reais, consensuais e literais, mais tarde acrescidas dos pacta adjecta e dos contratos inominados ${ }^{159}$.

E conclui haver sido o negócio jurídico para os romanos um conceito antes sentido que elaborado, mas definitivamente reconhecido como fenômeno jurídico, sendo desse modo um conceito de origem popular e social, diferente do pregam os liberais, derivando-o da autonomia da vontade, como também do que pregam os totalitários, que o recobram no ordenamento jurídico positivo ${ }^{160}$.

\section{História do Direito Romano}

José Carlos Moreira Alves delimita o direito romano como o conjunto de regras que disciplinaram a sociedade romana das suas origens até a morte do Imperador Justiniano em 465 d.C. e pondera que para a melhor apreensão do seu objeto é necessário que se empreenda uma investigação histórica, a qual distingue o autor entre a história externa, condizente às instituições políticas, as fontes do direito e a jurisprudência, e a história interna de Roma, esta voltada para as instituições do direito privado $^{161}$.

Antonio Junqueira de AzEvedo, Ciência do Direito, Negócio Jurídico e Ideologia, in Estudos e Pareceres de Direito Privado, São Paulo, Saraiva, 2004, p. 46:

"Da Lei das XII Tábuas em diante, não resta dúvida, as formas negociais no Direito Romano se multiplicaram. Na evolução do direito contratual, por exemplo, o alargamento dos tipos de acordo, a que se reconhece valor jurídico, é constante (depois do negócio per aes et libram, aparecem os quatro tipos contratuais denominados verbais, reais, consensuais e literais; depois, os pactos adjectos, pretorianos e legítimos; finalmente, possivelmente no período pós-clássico, a categoria dos inominados). (...)".

Antonio Junqueira de AzEVEDo, Ciência do Direito, Negócio Jurídico e Ideologia, in Estudos e Pareceres de Direito Privado, São Paulo, Saraiva, 2004, pp. 46 e 47:

"Como quer que seja, esse conceito 'antes sentido que elaborado', atribuído aos juristas romanos, é a idéia clara, mas confusa, do negócio jurídico, que sustentamos ser comum a qualquer povo. Um exame da história do direito seria instrutivo; há sempre determinados modos de comportamento socialmente reconhecíveis como jurídicos: pronunciam-se palavras sacramentais, insiste-se no caráter vinculante do ato, chamam-se várias testemunhas, realizam-se gestos estereotipados, entregam-se títulos (traditio, chartae) ou objetos com os mais variados nomes (arrhae, denarius Dei Launegild, palmata, res, cosa, consideration). Todos sabem o que é jurídico, na sua nação. Ora, se o negócio jurídico é, antes de tudo, um conceito popular, seu fundamento é a autonomia de vontade socialmente entendida. Não é, portanto, nem a autonomia de vontade individualista, como se pretende no liberalismo capitalista, nem a autonomia de vontade concedida pelo ordenamento jurídico, como se quer no totalitarismo estatizante".

"Direito romano é o conjunto de normas que regeram a sociedade romana desde as origens (segundo a tradição, Roma foi fundada em 754 a.C.) até o ano 565 d.C., quando ocorreu a morte do imperador Justiniano.

(...)

Essa introdução corresponde ao que alguns romanistas denominam história externa do direito romano. Já o estudo das instituições de direito privado é o objeto da história interna. Os modernos 
Sob a perspectiva da história externa, o primeiro período remonta à Realeza, que assim como a origem de Roma, é marcadamente lendário, mas permite inferir o domínio do povo etrusco sobre a cidade e sobre os primitivos romanos ${ }^{162}$. As fontes do direito, como é cediço aos povos primitivos, centram-se nos costumes (mos maiorum), espontaneamente transmitidos pelas gerações independente de órgãos legiferantes ${ }^{163}$. A jurisprudência, entendida como ciência do direito, era no período marcadamente sacerdotal, caracterizada por extremo formalismo no tocante às fórmulas para celebração de contratos ou proposição de ações judiciais, sendo o "calendário judiciário", dividido entre os dias fas e nec fas, de exclusivo conhecimento dos pontífices $^{164}$.

autores italianos e alemães à primeira denominação (história externa) preferem história do direito romano; à segunda (história interna), instituições de direito romano (italianos) ou sistema de direito privado romano (alemães).

Tanto a história externa quanto a interna se dividem em períodos, a respeito de cuja delimitação os autores divergem. Adotaremos, para a história externa, a divisão que se baseia nas diferentes formas de governo que teve Roma. Assim:

$1^{\circ}$ - período real (vai das origens de Roma à queda da realeza em 510 a.C.);

$2^{\circ}$ - período republicano (de 510 a 27 a.C., quando o Senado investe Otaviano - o futuro Augusto no poder supremo com a denominação de princeps);

$3^{\circ}$ - período do principado (de 27 a.C. a 285 d.C., com o início do dominato por Diocleciano);

$4^{\circ}$ - período do dominato (de 285 a 565 d.C., data em que morre Justiniano).

Quanto à história interna, seguiremos a seguinte divisão, em três fases:

$1^{\mathrm{a}}$ - a do direito antigo ou pré-clássico (das origens de Roma à Lei Aebutia, de data incerta, compreendida aproximadamente entre 149 e 126 a.C.).

$2^{\mathrm{a}}$ - a do direito clássico (daí ao término do reinado de Diocleciano, em 305 d.C.); e

$3^{\mathrm{a}}$ - a do direito pós-clássico ou romano-helênico (dessa data à morte de Justiniano, em 565 d.C. dá-se, porém, a designação de direito justinianeu ao vigente na época em que reinou Justiniano, de 527 a 565 d.C.)".

José Carlos MoreIRA Alves, Direito Romano, $15^{\mathrm{a}}$ ed., Rio de Janeiro, Forense, 2012, p. 7:

"As origens de Roma são lendárias. Mesmo os sete reis (Rômulo; Numa Pompílio; Tulo Hostílio; Anco Márcio; Tarquínio, o Prisco; Sérvio Túlio; e Tarquínio, o Soberbo) não foram personagens históricas. Mas em toda lenda há sempre um fundo de verdade. O fato de os três últimos serem de origem etrusca demonstra a existência de uma fase, nos primórdios de Roma, em que esta foi subjugada pelos etruscos, misterioso povo localizado ao norte de Roma, e sobre o qual muito pouco sabemos, pois até hoje sua língua é para nós um enigma. O certo, porém, é que os etruscos nação altamente civilizada para a época - exerceram grande influência sobre os primitivos romanos".

163 José Carlos MoreIRA Alves, Direito Romano, 15 a ed., Rio de Janeiro, Forense, 2012, pp. 11 e 12: "Todos os povos primitivos começam a reger-se pelo costume - complexo de usos praticados pelos antepassados e transmitidos às gerações pela tradição -, pois é ele espontâneo, independente, portanto, da existência de órgãos que o elaborem. Roma não fugiu a essa regra: o mos maiorum (costume) foi fonte de direito, na realeza".

164 José Carlos Moreira Alves, Direito Romano, 15ª ed., Rio de Janeiro, Forense, 2012, pp. 12 e 13: "Nos tempos primitivos, a jurisprudência romana era monopolizada pelos pontífices. Esse monopólio - em decorrência do rigoroso formalismo que caracteriza o direito arcaico - consistia em deterem os pontífices o conhecimento, não só dos dias em que era permitido comparecer a juízo (dias fastos, em contraposição aos nefastos, em que era isso proibido), mas também das fórmulas com que se celebravam os contratos ou com que se intentavam as ações judiciais". 
A organização social do povo romano se dava por meio de tribos, derivadas das três raças originárias da cidade: os latinos, sabinos (quirites) e etruscos. Essas tribos, por seu turno se organizavam em familias sob o comando supremo dos paterfamilias. Estes chefes detinham poderes absolutos sobre as pessoas reunidas em torno das suas famílias, conceito que não se confunde com o contemporâneo, uma vez que o grupo familiar romano tinha contornos diferentes, abarcando todos o membros ligados pelo tronco masculino comum do paterfamilias, quem ostentava os poderes de pai, de magistrado e de sacerdote sobre todos os seus filiusfamilias ${ }^{165}$.

O segundo período é a República, marcada pelo poder de magistrados, com diferentes designações ao longo do tempo, e pela luta entre patrícios e plebeus pela segurança jurídica estribada em leis escritas e pela ocupação de funções relevantes na magistratura republicana ${ }^{166}$. As fontes do direito são o costume ${ }^{167}$, ainda preponderante

Reynaldo PoRchat, Curso Elementar de Direito Romano, vol. I, $2^{\mathrm{a}}$ ed., São Paulo, Melhoramentos, 1937, p. X:

"A primitiva organisação do povo de Roma era em tribus: tres tribus decorrentes das tres raças originarias acima mencionadas.

As tribus eram organisadas em familias, que viviam sob o poder de um chefe denominado Pater Familias.

Este chefe tinha um poder absoluto sobre todos os membros da familia, inclusive o poder de vida e de morte. Elle, na familia, desempenhava todas as funç̧ões sociaes e politicas: era o pai, o juiz, o poder executivo, o sacerdote. Cumpre notar que a familia romana, a que nos estamos referindo, não era exactamente egual á familia no conceito moderno.Ella comprehendia todos os membros derivados de um tronco masculino, e esse tronco era o Pater, que era quem praticava todas as cerimonias religiosas e a cujo poder estavam todos sujeitos, vinculados pelo parentesco chamado por agnação - agnatio -, isto é, derivado exclusivamente da linha masculina ou paterna. Mesmo quando o pai passava a ser avô ou bisavô, etc., continuava a ser o Pater da familia, exercendo o seu poder absoluto sobre os filhos, netos, bisnetos, etc. Elle era o centro ao redor do qual se reunia submissa a familia".

José Carlos MoreIRA Alves, Direito Romano, 15ª ed., Rio de Janeiro, Forense, 2012, pp. 15 a 17: "Segundo a tradição, a realeza terminou de modo abrupto: uma revolução baniu Tarquínio, o Soberbo, de Roma, em 510 a.C. Ao rei sucedem dois magistrados eleitos anualmente, e que se denominam, a princípio, iudices (juízes), em tempo de paz, e praetores (os que vão à frente), quando em guerra. Excetuadas as funções religiosas que passaram para o rex sacrorum e para o pontifex maximus, esses magistrados detêm o imperium real.

(...)

Seguiu-se a luta da plebe para a obtenção de leis escritas, o que acabaria com a incerteza do direito e daria mais segurança aos plebeus. O resultado desse movimento foi a Lei das XII Tábuas, elaborada em 450 e 449 a.C.

(...)

Assim, a luta das duas classes, que se arrastara por séculos, terminou, na terceira centúria antes de Cristo, com a vitória da plebe, que conseguiu admissão a todas as magistraturas patrícias e a quase todas as funções sacerdotais, ao passo que o patriciado jamais obteve ingresso nas magistraturas plebéias (tribunato e edilidade da plebe).

Com a igualdade política entre patrícios e plebeus, desaparece a distinção social entre as duas classes, e surge, então, uma nova aristocracia, a nobilitas, a que pertencem todas as famílias que contam, entre seus antepassados, com um ou mais membros que ocuparam magistratura curul (ditadura, consulado, pretura, censura, edilidade curul)". 
no direito privado em razão do trabalhos jurisconsultos encarregados de regrar as relações sociais adaptando a tradição primitiva cujas origens já se tinham perdido ${ }^{168}$, a $l e i^{169}$, que ostentava as modalidades de lex rogata e lex data ${ }^{170}$, e os editos dos magistrados, estes consistentes em verdadeiros "programas de governo" que os magistrados apresentavam no início do exercício da magistratura e dos quais constavam os direitos aos quais ofereceriam tutela e, por exclusão, aqueles aos quais negariam proteção, visto que não previstos, o que redundava em verdadeira criação jurídica ${ }^{171}$. A jurisprudência exerce grande influência no desenvolvimento do direito romano em decorrência da atividade dos jurisconsultos exercida sob três aspectos: cauere, agere e respondere, significando a primeira o auxílio na redação formular dos negócios jurídicos, a segunda o mesmo auxílio no tocante à fórmulas, contudo exercido em juízo, e a terceira as respostas a consultas endereçadas aos iurisconsultus ${ }^{172}$.

Em decorrência da crescente expansão territorial e do fortalecimento dos exércitos, sobretudo dos seus comandantes, as instituições republicanas são colocadas

"Mores sunt tacitus consensus populi, longa consuetudine inveteratus" - "Os costumes são o tácito consentimento do povo inveterado pela longa repetição".

José Carlos MoreIRA Alves, Direito Romano, $15^{\mathrm{a}}$ ed., Rio de Janeiro, Forense, 2012, p. 23:

"É ele, no período republicano, a fonte preponderante do direito privado, graças à atividade dos jurisconsultos, que disciplinaram as novas relações sociais pela adaptação das normas primitivas que a tradição transmitira de geração a geração, mas cuja origem se perdera nas brumas de um passado remoto".

169 Gaetano SCIASCIA, Regras de Ulpiano, São Paulo, Leia, 1952, pp. 2 e 3:

"Lex aut rogatur, id est fertur, aut abrogatur, id est prior lex tollitur, aut derogatur, id est pars primae legi, aut obrogatur, id est mutatur aliquid ex prima lege..." - "A lei é rogada, quando proposta; abrogada, quando abole a lei anterior; derrogada, quando suprime uma parte da lei anterior; subrogada, quando acrescente algo à primeira lei; obrogada, quando altera algo da primeira lei".

170 José Carlos MoreIRA Alves, Direito Romano, $15^{\mathrm{a}}$ ed., Rio de Janeiro, Forense, 2012, p. 24 :

"Sob duas modalidades apresenta-se a lei em Roma: lex rogata (a proposta de um magistrado aprovada pelos comícios, ou a de um tribuno da plebe votada pelos concilia plebis, desde quando os plebiscitos se equipararam às leis) e lex data (lei emanada de um magistrado em decorrência de poderes que, para tanto, lhe concederam os comícios)".

171 José Carlos Moreira Alves, Direito Romano, $15^{\mathrm{a}}$ ed., Rio de Janeiro, Forense, 2012, p. 24 :

"O edito, a princípio, era a proclamação oral de uma espécie de programa do magistrado (o daqueles com função judiciária é um verdadeiro inventário de todos os meios de que o particular pode valer-se para obter a tutela de seu direito), no início do ano em que desempenharia a magistratura. Posteriormente, de oral, passou ele a ser escrito numa tábua pintada de branco, e, por isso, denominada album. Com o tempo, essa designação (album) foi dada ao próprio edito". José Carlos Moreira Alves, Direito Romano, $15^{\mathrm{a}}$ ed., Rio de Janeiro, Forense, 2012, pp. 28 e 29: "Os jurisconsultos, que em Roma desfrutaram de imenso prestígio, exerceram acentuada influência sobre o desenvolvimento do direito romano, graças, principalmente, a três aspectos de sua atividade: cauere, agere e respondere. Cauere é expressão técnica que indica a atuação do jurista no formular e redigir os negócios jurídicos, para evitar prejuízo à parte interessada, por inobservância de formalidades; agere é a atividade - no que concerne ao processo - semelhante à desenvolvida no cauere; e respondere diz respeito aos pareceres dos jurisconsultos sobre questões de direito controvertidas". 
em xeque e se inaugura um período de transição, o Principado, que encaminha Roma para o absolutismo, com o consequente e paulatino enfraquecimento das atribuições das instituições políticas da República ${ }^{173}$. Aumenta no período o rol das fontes do direito, figurando além do costume, que perde relevância em razão da sua constante absorção como norma do ius honorarium por meio dos editos pretorianos ${ }^{174}$, as leis comiciais, os editos dos magistrados, os senatusconsultos, os quais de início ganham importância por causa do esvaziamento dos comícios e porque o Príncipe antes de usurpar a competência legislativa, submetia suas proposições ao Senado que sobre elas deliberava $^{175}$, as constituições imperiais, fruto da interferência do príncipe na criação do direito, a despeito dessa prerrogativa não lhe haver sido expressamente outorgada ${ }^{176}$, e as repostas dos jurisconsultos. Esta última modalidade de fonte do direito, introduzida por Augusto como ius respondendi ex auctoritate principis, alçou as respostas de alguns jurisconsultos às consultas que lhes eram formuladas ao status de fonte do direito capaz de vincular a opinião dos juízes ${ }^{177}$.

173 José Carlos Moreira Alves, Direito Romano, $15^{\mathrm{a}}$ ed., Rio de Janeiro, Forense, 2012, pp. 32 e 33: "O principado apresenta dupla faceta: em Roma, é ele monarquia mitigada, pois o príncipe é apenas o primeiro cidadão, que respeita as instituições políticas da república; nas províncias imperiais, é verdadeira monarquia absoluta, porque o princeps tem, aí, poderes discricionários. Mas o principado, como regime de transição da república à monarquia absoluta, encaminha-se, paulatinamente, para o absolutismo.

(...)

(...), no principado subsistiram as instituições políticas da república, mas com suas atribuições cada vez mais reduzidas, por se tratar de regime de transição para a monarquia absoluta, a qual é incompatível com essas instituições nos moldes em que existiram na república".

174 José Carlos Moreira Alves, Direito Romano, $15^{\mathrm{a}}$ ed., Rio de Janeiro, Forense, 2012, p. 36 :

"Os juristas clássicos (Gaio, Inst. I, 2; e Papiniano, D. I, 1, 7, pr. e 1) não incluem o costume na relação das fontes do direito. $\mathrm{E}$ isso talvez porque eles consideram o costume como um fato. $\mathrm{O}$ que é certo, porém, é que sua importância, nesse período, é menor do que nos anteriores, até porque, quando começava a formar-se um costume, o pretor podia acolhê-lo em seu edito, dando-lhe o caráter de norma do ius honorarium".

175 José Carlos Moreira Alves, Direito Romano, $15^{\mathrm{a}}$ ed., Rio de Janeiro, Forense, 2012, p. 38:

"No início do principado, porém, os senatusconsultos passam a ser fonte de direito, não só em virtude do exaurimento do poder legislativo dos comícios, como também pela circunstância de que, não estando ainda os tempos devidamente amadurecidos para que o princeps, abertamente, usurpasse o poder legislativo, propunha ele as medidas que lhe pareciam necessárias, e o Senado sobre elas deliberava. Com o tempo, e graças à autoridade do príncipe, a proposta passa a ter mais valor do que a deliberação do Senado, uma vez que este se manifesta sempre pela aprovação. Daí, em vez de falar-se em senatusconsultum, dizer-se oratio (proposta do príncipe). (..)".

176 José Carlos Moreira Alves, Direito Romano, $15^{\mathrm{a}}$ ed., Rio de Janeiro, Forense, 2012, p. 38:

"Ao príncipe jamais foi atribuída expressamente a faculdade de legislar, mas em decorrência dos poderes que absorveu das magistraturas republicanas e da auctoritas que lhe era reconhecida, ele, desde o início do principado, interferiu na criação do direito, com as constitutiones (constituições imperiais), que não indicavam um ato formal do princeps para criar direito, mas qualquer ato dele emanado, e que eram fonte de direito quando continham novo preceito jurídico".

José Carlos MoreIRA Alves, Direito Romano, $15^{\mathrm{a}}$ ed., Rio de Janeiro, Forense, 2012, p. 39: 
O último interregno histórico é o Dominato, caracterizado pela extensão do poder absoluto do Príncipe das províncias também para Roma. Implantada a monarquia absoluta por Diocleciano, nova organização é conferida ao Império Romano, marcada no que toca às instituições políticas pela burocratização, sobrevivendo das magistraturas republicanas, com relevância exclusivamente honorífica e formal, tão somente o consulado, a pretura urbana, o tribunato da plebe e o Senado ${ }^{178}$. No âmbito das fontes do direito, persistem o costume, porém limitado à função de preencher lacunas, e as fontes dos períodos anteriores que não foram revogadas, preponderando a constituição imperial, agora denominada lex. A jurisprudência expõe sua decadência e é dominada por práticos, conhecedores do direito não por meio das fontes, mas por intermédio dos juristas clássicos ${ }^{179}$.

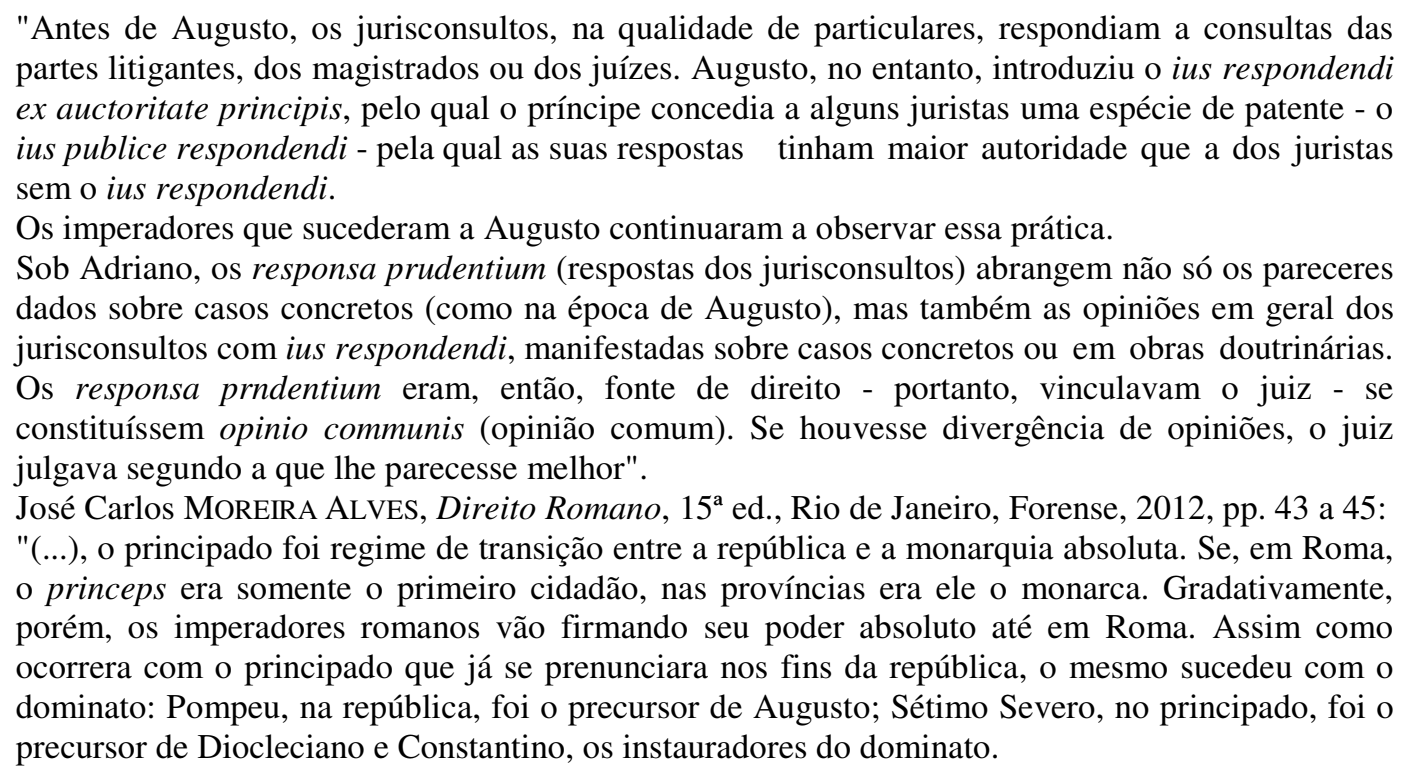
(...)

O dominato, quanto às instituições políticas, se caracteriza por ampla burocratização administrativa.

(...)

Das magistraturas originárias da república, persistem no dominato o consulado (com funções puramente honoríficas), a pretura urbana (sem jurisdição e com o ônus de a suas expensas, dar jogos públicos) e o tribunato da plebe (com existência apenas nominal; desaparece no século V).

O Senado, nesse período, reduz-se à condição de mero conselho municipal. Existe um em Roma, e outro em Constantinopla".

José Carlos Moreira Alves, Direito Romano, 15ª ed., Rio de Janeiro, Forense, 2012, pp. 45 e 46 :

"No principado, por ser período de transição, encontramos o maior número de fontes de direito que Roma conheceu sob determinado regime. No dominato (monarquia absoluta), há apenas uma fonte atuante de criação organizada do direito: a constituição imperial (então denominada lex). A seu lado, persiste o costume como fonte espontânea de direito, mas limitado a preencher as lacunas das constituições imperiais, sendo pequena sua importância para o direito privado. No entanto, continuam em vigor as normas decorrentes das fontes de direito dos períodos anteriores, desde que não revogadas. E, como no início do dominato é muito acentuada a decadência da jurisprudência - não há grandes juristas, mas, sim, práticos -, conhecem-se essas normas não do estudo da própria fonte, mas, indiretamente, por intermédio da obra dos jurisconsultos clássicos. Por isso, ao lado 
Além da acentuada redução das fontes formais do direito e da sua concentração nos preceitos emanados direta ou indiretamente do imperador, também os pretores, que muito contribuíram para o direito, perdem a relevância de sua atuação com a edição com força obrigatória do Edito Perpétuo, que desestimula os magistrados a elaborarem seus próprios editos e os induzem a meramente repetir os antecedentes ${ }^{180}$.

Da mesma forma se tornou escassa a produção jurisprudencial, verificando-se sensível desinteresse pelo estudo do direito, limitando-se o imperador e os juristas a voltarem ao passado para citar com autoridade os pronunciamentos dos jurisconsultos clássicos $^{181}$.

\section{Instituições de Direito Romano}

No plano da história interna do direito romano, no que se prefere a designação de "instituições de direito privado romano", é necessário proceder à advertência preliminar de que não é possível se apreender o direito privado como se faz com o mesmo direito, porém contemporâneo, visto que aquele não mais tem aplicabilidade, porém desperta interesse na medida em que sua evolução histórica traduz um essencial elemento de conhecimento dos institutos ainda hoje presentes no direito moderno ${ }^{182}$.

das constituições imperiais (leges), vigora, também, o direito contido nessas obras (e que é denominado, nesse tempo, iura)"; Melhoramentos, 1937, p. XXXVII:

"As fontes do direito ficaram verdadeiramente reduzidas ás constituições imperiaes. As leis, os plebiscitos e os senatus-consultus, muito raros, só existiam na fórma obedecendo cegamente ás ordens do principe. Os pretores perderam a sua importancia, e o direito pretoriano, que foi um dos maiores factores do desenvolvimento do direito romano no tempo da republica e nos primeiros tempos do imperio, enriquecendo-o com a adopção dos principios do jus gentium, entrou a declinar depois da approvação do Edicto Perpetuo, organisado por Juliano, e approvado por um senatus-consulto do imperador Adriano. A força obrigatoria dada a essa colleção pelo referido senatus-consulto diminuiu o interesse dos pretores ao elaborarem os seus edictos, que reproduziam em grande parte os edictos anteriores, com força de lei".

Reynaldo PoRChAT, Curso Elementar de Direito Romano, vol. I, $2^{\mathrm{a}}$ ed., São Paulo, Melhoramentos, 1937, p. XXXVIII:

"Tambem a obra dos jurisconsultos começou a decahir logo depois do apogeu a que attingira no tempo do imperador Alexandre Severo. Após essa época só tres jurisconsultos escreveram trabalhos de que foram extrahidos fragmentos para o Digesto: Hermogenianus, Aurelius Arcadius Charisius e Julius Aquila. As regulamentações das responsa, dos prudentium, a que já nos referimos, teve o effeito de fazer com que diminuisse o interesse pelo estudo da jurisprudencia, e porisso as vistas dos juristas, assim como as dos imperadores, se volveram para o passado, recorrendo-se á autoridade dos jurisconsultos classicos. Iniciou-se o regimen das citações, de que muito se abusou; e generalizou-se a moda das collecções, distinguindo-se, corno já se fazia anteriormente, a parte chamada jura ou opiniões doutrinarias dos jurisconsultos, e leges que eram as constituições imperiaes promulgadas pelos imperadores". 
Várias regras que regularam as relações entre os indivíduos no direito romano foram recepcionadas pelos sistemas jurídicos modernos, a ponto de em alguns deles se verificar influência tão profundo que se denominam hoje sistemas jurídicos de base romanística ${ }^{183}$.

Nessa perspectiva, divide-se a história interna do direito romano em três períodos, cujos limites são meramente didáticos, porém em cujos lapsos temporais evolutivos é possível se verificar características comuns e marcantes entre os diversos institutos $^{184}$.

O período pré-clássico ou arcaico caracteriza-se pelo extremo formalismo, solenidade e primitivismo, marcado pela distância do Estado Romano das questões de direito e pelo uso da defesa privada dos interesses. A evolução nesse período se dá no

"Em nossos dias, não se pode estudar o direito privado romano como se estuda o direito privado moderno. E a razão é esta: o direito privado moderno se aprende, principalmente, com vistas à sua utilização prática, motivo por que é analisado como se apresenta no momento atual; já o direito romano não mais se aplica, e continua a ser estudado somente como direito histórico, que vigorou no passado e que, ainda hoje, serve de instrumento de educação jurídica, uma vez que o exame de sua evolução é notável campo de observação do fenômeno jurídico em todos os seus aspectos, razão por que cada um dos institutos que o compõem deverá ser examinado em sua evolução histórica, das origens ao termo final. (...)".

Alexandre CORRÊA e Gaetano SCIASCIA, Manual de Direito Romano, $6^{\mathrm{a}}$ ed., São Paulo, RT, 1988, p. 13:

"Da data da fundação da cidade aos nossos dias, várias vicissitudes históricas, sociais e políticas, ocasionaram a recepção da parte do direito romano, que regula as relações dos indivíduos entre si (direito privado romano), pelos sistemas jurídicos dos países modernos. Em muitos dêstes o direito romano foi acolhido tão amplamente, de maneira a autorizar a denominação de países com sistema jurídico de base romanística, como por exemplo, quase todos os da Europa continental, da América Latina e até mesmo do Extremo Oriente, como o Japão. Em outros a acolhida não foi tão grande, e o sistema jurídico sofreu evolução diversa e independente das normas romanas. A Inglaterra e os Estados Unidos dizem-se países com sistema jurídico anglo-saxão. Não faltam enfim sistemas jurídicos de base mista, i. é, o sistema jurídico romano coexistente com o anglosaxão".

184 José Carlos MoreIRA Alves, Direito Romano, $15^{\mathrm{a}}$ ed., Rio de Janeiro, Forense, 2012, p. 72:

"Em face disso, e para facilitar esse estudo evolutivo, os romanistas dividem a história interna do direito romano em períodos, a respeito de cuja delimitação e número, no entanto, divergem. Das várias divisões adotamos a seguinte, em três fases:

$1^{\mathrm{a}}$ - a do direito antigo ou pré-clássico (das origens de Roma à Lei Aebutia, de data incerta, compreendida aproximadamente entre 149 e 126 a.C.);

$2^{\mathrm{a}}$ - a do direito clássico (daí ao término do reinado de Diocleciano, em 305 d.C.; o período áureo dessa época vai de 96 a 235 d.C.); e

$3^{\mathrm{a}}$ - a do direito pós-clássico ou romano-helênico (dessa data à morte de Justiniano, em 565 d.C. dá-se, porém, a designação de direito justinianeu ao vigente na época em que reinou Justiniano, de 527 a 565 d.C.).

As datas-limites desses períodos - das quais a finalidade é mais didática do que científica indicam, de modo geral, o lapso de tempo dentro do qual se verificaram, mais acentuadamente, certas diretrizes na evolução dos diferentes institutos jurídicos. Por isso, e para que se possa compreender como e por que os institutos evoluíram dessa ou daquela maneira, é imprescindível que se conheçam as características de cada uma dessas três etapas. (...)". 
sentido de aumentar o poder e presença do estado e reforçar a autonomia e segurança jurídica do ciuitas e tem seu ápice com a edição da Lei das XII Tábuas, codificação das regras costumeiras e primitivas até então vigentes, mas ainda muito contaminadas por prescrições de índole religiosa $^{185}$.

Evidente que este direito primitivo, mesmo que codificado, com o tempo tornouse inadequado à disciplina da sociedade romana, especialmente no momento em que por meio de conquistas expandiam seu território e já dominavam todo o Mediterrâneo. Inaugura-se então o período clássico, apogeu do direito e da jurisprudência romana, cujas inovações e aprimoramentos verificados são devidos fundamentalmente aos magistrados e aos jurisconsultos, que a despeito de inicialmente não disporem da prerrogativa de criar ou modificar regras de direito, faziam-no no exercício de suas atividades adaptando as normas jurídicas ao seu tempo ${ }^{186}$.

Thomas Marky, Curso Elementar de Direito Romano, $8^{\mathrm{a}}$ ed., São Paulo, Saraiva, 1995, p. 6:

"O direito do período arcaico caracterizava-se pelo seu formalismo e pela sua rigidez, solenidade e primitividade. O Estado tinha funções limitadas a questões essenciais para sua sobrevivência: guerra, punição dos delitos mais graves e, naturalmente, a observância das regras religiosas.

Os cidadãos romanos eram considerados mais como membros de uma comunidade familiar do que como indivíduos. A defesa privada tinha larga utilização: a segurança dos cidadãos dependia mais do grupo a que pertenciam do que do Estado.

A evolução posterior caracterizou-se por acentuar-se e desenvolver-se o poder central do Estado e, conseqüentemente, pela progressiva criação de regras que visavam a reforçar sempre mais a autonomia do cidadão, como indivíduo.

O marco mais importante e característico desse período é a codificação do direito vigente nas XII Tábuas, codificação feita em 451 e 450 a.C. por um decenvirato, especialmente nomeado para esse fim.

As XII Tábuas, chamadas séculos depois, na época de Augusto (século I), fonte de todo o direito (fons omnis publici privatique iuris), nada mais foram que uma codificação de regras provavelmente costumeiras, primitivas, e, às vezes, até cruéis. Aplicavam-se exclusivamente aos cidadãos romanos.

Esse direito primitivo, intimamente ligado às regras religiosas, fixado e promulgado pela publicação das XII Tábuas, já representava um avanço na sua época, mas, com o passar do tempo e pela mudança de condições. tornou-se antiquado, superado e impeditivo de ulterior progresso.

Mesmo assim, o tradicionalismo dos romanos fez com que esse direito arcaico nunca fosse considerado como revogado: o próprio Justiniano, 10 séculos depois, fala dele com respeito".

"A conquista do poder, pelos romanos, em todo o Mediterrâneo, exigia uma evolução equivalente no campo do direito também. Foi aqui que o gênio romano atuou de uma maneira peculiar para a nossa mentalidade.

A partir do século II a.C. assistimos a uma evolução e renovação constante do direito romano, que vai até o século III d.C., durante todo o período clássico. Essa revolução e renovação se fez, porém, por meios indiretos, característicos dos romanos e diferentes dos métodos modernamente usados.

A maior parte das inovações e aperfeiçoamentos do direito, no período clássico, foi fruto da atividade dos magistrados e dos jurisconsultos que, em princípio, não podiam modificar as regras antigas, mas que, de fato, introduziram as mais revolucionárias modificações para atender às exigências práticas de seu tempo". 
Da extensa plêiade de magistrados romanos, sobretudo no período republicano, deve-se destacar a atividade do pretor, que desempenhava atividades de administração da justiça e a quem cabia o preparo das demandas entre os particulares, redigindo a fórmula que descrevia as alegações das partes e fixava os pontos da discussão, seguindo depois para o julgamento do juiz nomeado para dirimir a contenda. Existiam o pretor urbano, para os casos envolvendo cidadãos romanos, e o pretor peregrino, incumbido dos casos com a presença dos estrangeiros ${ }^{187}$.

Os pretores detinham o poder de imperium, que lhes conferia a prerrogativa de ao fixar os limites da demanda, também exarar instruções para a apreciação jurídica da causa pelo juiz, incluindo novos entendimentos até então não observados no direito vigente. Além disso, detinham a discricionariedade de admitir ou inadmitir causas, inovando o direito acolhendo direitos novos ou negando vigência a regras antigas. Esses desígnios jurídicos adotados no período de exercício da magistratura eram antecipados e publicados pelos pretores ao assumirem os seus cargos, por meio dos editos, os quais compuseram um verdadeiro conjunto de regras, mais tarde também codificadas ${ }^{188}$.

Thomas MARKY, Curso Elementar de Direito Romano, $8^{\text {a }}$ ed., São Paulo, Saraiva, 1995, p. 7:

"Entre os magistrados republicanos, o pretor tinha por incumbência funções relacionadas com a administração da Justiça. Nesse mister, cuidava da primeira fase do processo entre particulares, verificando as alegações das partes e fixando os limites da contenda, para remeter o caso posteriormente a um juiz particular. Incumbia, então, a esse juiz, verificar a procedência das alegações diante das provas apresentadas e tomar, com base nelas, a sua decisão. Havia pretor para os casos entre cidadãos romanos - era o pretor urbano - e havia também, a partir de 242 a.C., pretor para os casos em que figuravam estrangeiros. Era o chamado pretor peregrino". Thomas MARKY, Curso Elementar de Direito Romano, $8^{\text {a }}$ ed., São Paulo, Saraiva, 1995, pp. 7 e 8 : "O pretor, como magistrado, tinha um amplo poder de mando, denominado imperium. Utilizou-se dele, especialmente, a partir da lei Aebutia, no século II a.C., que, modificando o processo, lhe deu ainda maiores poderes discricionários. Por essas modificações processuais, o pretor, ao fixar os limites da contenda, podia dar instruções ao juiz particular sobre como ele deveria apreciar as questões de direito. Fazia isto por escrito, pela formula, na qual podia incluir novidades, até então desconhecidas no direito antigo. Não só. Com esses poderes discricionários, podia deixar de admitir ações perante ele propostas (denegatio actionis) ou, também, admitir ações até então desconhecidas no direito antigo. Essas reformas completavam, supriam e corrigiam as regras antigas (Ius praetorium est, quod praetores introduxerunt adiuvandi vel supplendi vel corrigendi iuris civilis gratia. D. 1.1.7.1).

As diretrizes que o pretor ia observar eram publicadas no seu Edito, ao entrar no exercício de suas funções. Como o cargo de pretor era anual, os editos se sucediam um ao outro, dando oportunidade a experiências valiosíssimas.

O resultado dessas experiências foi um corpo estratificado de regras, aceitas e copiadas pelos pretores que se sucediam, e que, finalmente, por volta de 130 d.C., foram codificadas pelo jurista Sálvio Juliano, por ordem do Imperador Adriano.

Note-se bem, entretanto, que esse direito pretoriano nunca foi equiparado ao direito antigo (ius civile). A regra antiga, pela qual o pretor não podia criar direito (praetor ius facere non potest), continuou em vigor. Assim, esse direito pretoriano, constante do Edito e chamado ius honorarium, 
Também se destacaram no processo construtivo e evolutivo do direito no período clássico os jurisconsultos, cidadãos detentores de elevada distinção na sociedade romana em razão de seus predicados intelectuais, cuja atividade de interpretação do direito antigo, antes confiada restritamente aos sacerdotes, além de lhes permitir atualizar as velhas regras, também redundava na criação de novas normas jurídicas $^{189}$.

Isto porque a interpretação gratuitamente desempenhada pelos jurisconsultos clássicos consistia na emissão de pareceres (respondere), instrução das partes para atuação em juízo (agere) e orientação prestada na celebração de negócios jurídicos (cauere). Mais tarde é instituído privilégio para alguns juristas de emitirem suas opiniões em nome do príncipe (ius respondendi ex auctoritate principis), portando em caráter vinculativo e obrigatório, o que reforça a índole criativa, mesmo que em caráter casuístico, desses cultores do direito em Roma ${ }^{190}$.

foi sempre considerado como diferente do direito antigo (ius civile) mesmo quando, na prática, o substituiu".

Thomas MARKy, Curso Elementar de Direito Romano, $8^{a}$ ed., São Paulo, Saraiva, 1995, p. 8:

"A interpretação das regras do direito antigo era tarefa importante dos juristas. Originariamente só os sacerdotes conheciam as normas jurídicas. A eles incumbia, então, a tarefa de interpretá-las. Depois, a partir do fim do século IV a.C., esse monopólio sacerdotal da interpretação cessou, passando ela a ser feita também pelos peritos leigos. Essa interpretação não consistia somente na adaptação das regras jurídicas às novas exigências, mas importava também na criação de novas normas.

Tal atividade jurisprudencial contribuiu grandemente para o desenvolvimento do direito romano, especialmente pela importância social que os juristas tinham em Roma. Eles eram considerados como pertencentes a uma aristocracia intelectual, distinção essa devida aos seus dotes de inteligência e aos seus conhecimentos técnicos".

"Suas atividades consistiam em emitir pareceres jurídicos sobre questões práticas a eles apresentadas (respondere), instruir as partes sobre como agirem em juízo (agere) e orientar os leigos na realização de negócios jurídicos (cavere). Exerciam essa atividade gratuitamente, pela fama e, evidentemente, para obter um destaque social, que os ajudava a galgar os cargos públicos da magistratura.

Foi Augusto que, procurando utilizar, na nova forma de governo por ele instalada, os préstimos desses juristas, instituiu um privilégio consistente no direito de dar pareceres em nome dele, príncipe: ius respondendi ex auctoritate principis. Esse direito era concedido a certos juristas chamados jurisconsultos (Inst. 1.2.8). Seus pareceres tinham força obrigatória em juízo. Havendo pareceres contrastantes, o juiz estava livre para decidir.

O método dos jurisconsultos romanos era casuístico. Examinavam, explicavam e solucionavam casos concretos. Nesse trabalho não procuravam exposições sistemáticas: eram avessos às abstrações dogmáticas e às especulações e exposições teóricas. Isso não impediu, entretanto, que o gênio criador dos romanos se manifestasse por intermédio dessa obra casuística dos jurisconsultos clássicos". 


\section{O período pós-clássico é sublinhado pela decadência das instituições romanas e}

também do seu direito ${ }^{191}$. Ausente a criação, marcante no período clássico, sente-se a necessidade de se codificar as regras vigentes, o que não havia sido alvo de preocupação desde a Lei das XII Tábuas. Coube ao Imperador Justiniano a tarefa, cujo produto é o hoje conhecido Corpus Iuris Ciuile, codificação que preservou o direito romano ao longo dos tempos ${ }^{192}$.

191 Não é unânime a opinião de que à decadência política do período pós-clássico corresponderia também a decadência das instituições jurídicas. A despeito de se reconhecer a ausência dos grandes jurisconsultos que povoaram o período clássico, afirma-se nesse sentido a adaptação do direito romano aos princípios do Cristianismo, reconhecido em 322 por Constantino com religião oficial do Império Romano (Edito de Milão). Além disso, os vários sistemas de direito (ius ciuile, ius gentium e ius honorarium) se fundem e vão compor Copus Iuris Ciuile.

Alexandre CORRÊA e Gaetano SCIASCIA, Manual de Direito Romano, 6 ${ }^{\text {a }}$ ed., São Paulo, RT, 1988, p. 17:

"O período pós-clássico que começa com Diocleciano e se encerra com o direito justinianeu. A decadência política dêste período não corresponde, em certo sentido, à decadência jurídica. Se é verdade que faltam grandes jurisconsultos e os mestres do direito procuram simplificar a produção dos juristas clássicos, é também indiscutível que o direito romano contém em si a qualidade de se adaptar aos novos princípios sociais afirmados pelo Cristianismo, que entram como os fatôres mais importantes na natural transformação do direito. Os vários sistemas jurídicos do ius civile, do ius gentium, do ius honorarium, da cognitio extra ordinem se fundem num único corpo de direito. Nêste período se forma em definitivo o direito moderno, codificado no VI. ${ }^{\circ}$ século pelo imperador Justiniano".

Thomas Marky, Curso Elementar de Direito Romano, $8^{\text {a }}$ ed., São Paulo, Saraiva, 1995, pp. 8 a 10 :

"O último período, o pós-clássico, é a época da decadência em quase todos os setores. Assim, também no campo do direito. Vivia-se do legado dos clássicos, que, porém, teve de sofrer uma vulgarização, para poder ser utilizado na nova situação caracterizada pelo rebaixamento de nível em todos os campos.

Nesse período, pela ausência do gênio criativo, sentiu-se a necessidade da fixação definitiva das regras vigentes, por meio de uma codificação que os romanos em princípio desprezavam. Não é por acaso que, exceto aquela codificação das XII Tábuas do século V a.C., nenhuma outra foi empreendida pelos romanos até o período decadente da era pós-clássica.

Após tentativas parciais de codificação de partes restritas do direito vigente (Codex Gregorianus, Codex Hermogenianus, Codex Theodosianus), foi Justiniano (527 a 565 d.C.) quem empreendeu a grandiosa obra legislativa, mandando colecionar oficialmente as regras de direito em vigor na época.

Encarregou uma comissão de juristas de organizar uma coleção completa das constituições imperiais (leis emanadas dos imperadores), que foi completada em 529 e publicada sob a denominação de Codex (de que não temos texto nenhum).

No ano seguinte, em 530, determinou Justiniano que se fizesse a seleção das obras dos jurisconsultos clássicos, encarregando dessa tarefa Triboniano, que convocou uma comissão para proceder ao trabalho ingente.

A comissão conseguiu no prazo surpreendente de três anos confeccionar o Digesto (ou Pandectas), composto de 50 livros, no qual foram recolhidos trechos escolhidos de 2.000 livros (com três milhões de linhas) de jurisconsultos clássicos.

Os codificadores tiveram autorização de alterar os textos escolhidos, para harmonizá-los com os novos princípios vigentes.

Essas alterações tiveram o nome de emblemata Triboniani e hoje são chamadas interpolações. A descoberta de tais interpolações e a restituição do texto original clássico é uma das preocupações da ciência romanística dos últimos tempos.

Paralelamente à compilação do Digesto, Justiniano mandou preparar uma nova edição do Codex, isto por causa da vasta obra legislativa por ele empreendida naqueles últimos anos. Em 534 foi 
Um destaque que também remonta ao último período do direito romano, em razão da decadência da jurisprudência, cujos cultores se limitam a recorrer aos jurisconsultos clássicos, é a edição da Lei das Citações de 426. A norma institui um verdadeiro "tribunal dos mortos", fixando que somente ostentariam força de lei as opiniões dos juristas Papiniano, Ulpiano, Paulo, Modestino e Gaio, prevalecendo na hipótese de dissenso entre eles a posição da sua maioria e no caso de empate no dissenso, a posição de Papiniano, se existente sobre o assunto versado e se inexistente, somente então poderia o juiz decidir conforme melhor lhe aprouvesse. Justiniano, na sua compilação, atribui igual valor aos fragmentos colacionados no Digesto, o qual nomina de "coleção das obras dos juristas que gozaram do ius respondendi"193.

\section{Ressurreição e influência do Direito Romano}

Em caráter preliminar, é necessário ter em mente que o direito romano que chegou à atualidade e que exerceu profunda influência nos sistemas jurídicos ocidentais foi "redescoberto" e "reinventado" primeiro na Idade Média e posteriormente no século

publicado, então, o Codex repetitae praelectionis, o Código revisado, cujo conteúdo foi harmonizado com as novas normas expedidas no curso dos trabalhos. Somente temos o texto desta segunda edição do Código Justinianeu.

Além dessas obras legislativas, Triboniano, Teófilo e Doroteu, estes últimos professores das escolas de Constantinopla e de Berito, elaboraram, por ordem de Justiniano, um manual de direito para estudantes, que foi modelado na obra clássica de Gaio, do século Il a.C. Esse manual foi intitulado Institutiones, como o de Gaio, e foi publicado em 533.

Depois de terminada a codificação, a qual, especialmente o Código, continha a proibição de se invocar qualquer regra que nela não estivesse prevista, Justiniano reservou-se a faculdade de baixar novas leis.

Nos anos subseqüentes a 535, até sua morte em 565 d.C., Justiniano publicou efetivamente um grande número de novas leis, chamadas novellae constitutiones. A coleção destas, intitulada Novellae, constitui o quarto volume da codificação justinianéia.

O Código, o Digesto, as Institutas e as Novellae formam, então, o Corpus luris Civilis, nome esse dado por Dionísio Godofredo, no fim do século XVI d.C.

Foi mérito dessa codificação a preservação do direito romano para a posteridade".

193 Alexandre CorRÊA e Gaetano SCIASCIA, Manual de Direito Romano, 6a ed., São Paulo, RT, 1988, p. 28:

"No período pós-clássico, porém, com a decadência da jurisprudência, se citam e utilizam as respostas dos juristas clássicos. Com o fim de eliminar a confusão, que então se verificara, os imperadores Teodósio I e Valentiniano II baixaram a chamada Lei das Citações, em 426, pela qual somente as opiniões de Papiniano, Ulpiano, Paulo, Modestino, Gaio tinham fôrça de lei. No caso de discordância prevalecia a opinião da maioria; no de igualdade, a opinião de Papiniano quando alegada; em caso de não existir esta, o juiz podia seguir a opinião que mais oportuna lhe parecesse. A Lei das Citações, como mui bem se disse, institui 'um tribunal de mortos'.

Justiniano declara que o Digesto é uma coleção das obras dos juristas que gozaram do ius respondendi. A afirmação não é de todo exata, porque o Digesto contém trechos de juristas, como p. ex. Gaio, que não gozaram em vida do ius respondendi; o imperador porém, promulgando a sua compilação, atribuiu implicitamente valor de lei a todos os fragmentos dos juristas clássicos nela contidos ou de qualquer modo citados". 
XIX na Alemanha, de modo que não se pode recebê-lo e concebê-lo, do ponto de vista histórico, como foi criado e exercitado no ambiente cultural e institucional de Roma ${ }^{194}$.

Desse modo, com a queda do Império Romano do Ocidente, em 476, e a morte do Imperador Justiniano, em 565, entra o direito romano em estado latente, até que no século XII descobertas de manuscritos antigos ressuscitam o seu estudo por meio das universidades $^{195}$.

Essas universidades são criações medievais e nascem a partir dos séculos XI e XII. A primeira delas a gozar do consentimento público para o ensino do direito oriundo desses manuscritos a Escola de Bolonha, inicialmente liderada por Irnerius, quem por meio de suas lições e angariando considerável plêiade de discípulos, formou a Escola dos Glosadores, assim nominados em razão das suas técnicas de estudo das fontes romanas, vazadas em anotações entre as linhas do texto original (glosas interlineares) e também nas suas margens (glosas marginais) ${ }^{196}$.

194 José Reinaldo de Lima LOPES, O Direito na História - Lições Introdutórias, $4^{\mathrm{a}}$ ed., São Paulo, Atlas, 2012, pp. 15 e 16:

"(...) De fato, de alguma forma, inseridos que estamos na órbita da civilização ocidental, é claro que a herança romana nos chegou, assim como algo da herança grega. Apesar disso é bom lembrar que o direito romano só nos chega porque foi 'redescoberto' e verdadeiramente 'reinventado' duas vezes na Europa ocidental: a primeira vez nos séculos XII a XV e a segunda vez no século XIX, respectivamente pelos juristas da universidade medieval, glosadores e comentadores, e pelos professores alemães que tentavam a unificação jurídica nacional. Como toda 'volta' histórica, as redescobertas do direito romano foram um uso não previsto historicamente para decisões, sentenças e instituições. Nestes termos, a redescoberta do direito romano nunca veio acompanhada das mesmas instituições ou ambiente cultural originais e aqui será bom marcar estas diferenças". José Reinaldo de Lima LOPES, O Direito na História - Lições Introdutórias, ${ }^{\mathrm{a}}$ ed., São Paulo, Atlas, 2012, pp. 97 e 98:

"O início do ensino jurídico na tradição ocidental pode ser localizado na Baixa Idade Média. É certo que houve em Roma, no período da jurisprudência clássica, escolas de direito, que chegaram até a definir-se programaticamente dando origem a escolas de pensamento jurídico, dividindo-se entre proculianos (seguidores de Labeão, republicano aberto a inovações) e sabinianos (seguidores de Capito, imperial, inclinado à autoridade e à tradição). É também certo que houve escolas de direito no Império Romano do Oriente, em Constantinopla e Beirute (Berito), ao lado de outras menos importantes em Cesareia, Alexandria do Egito, Atenas e Antioquia. No Império do Ocidente, ou naquela parte que dele fez parte, sobreviveram alguns lugares de treinamento profissional em Roma, Ravena, Marselha, Toulouse (Tolosa, na França), Toledo, Sevilha. A serviço do ensino do direito foram feitos manuais introdutórios, cujo exemplo que sobreviveu foi o de Gaio (Instituições) e que serviu de modelo à comissão nomeada por Justiniano par consolidar o direito clássico (Instituições de Justiniano)".

196 Reynaldo PORCHAT, Curso Elementar de Direito Romano, vol. I, 2a ed., São Paulo, Melhoramentos, 1937, p. 7:

"A primeira escola que gosou do privilegio concedido, foi a de Bolonha, que teve á sua frente o grande lrnerius (...), que, segundo consta, aprendêra o direito em Constantinopla onde eram explicadas as Basilicas, e instituiu o ensino do direito romano distincto do da rhetorica e da grammatica com o qual sempre estivera confundido. 
Nessa escola medieval, destacou-se também Accursius, responsável pela composição da Magna Glosa ou Glosa Acursiana, trabalho que teve o condão de fixar a síntese dos estudos empreendidos pelos Glosadores e que a despeito de falhas apontadas pelos estudiosos, ostentou grande prestígio e autoridade, sendo por vezes invocado com força de lei ${ }^{197}$.

No século XIV, juristas munidos de maior liberdade de pensamento, detentores de um conhecimento mais consolidado e tendo à disposição maior número de cópias das fontes romanas ${ }^{198}$, formam a Escola dos Comentadores ou Pós-Glosadores, cujo maior expoente foi Bartholus. Essa escola lançou mão em seus métodos de estudo e interpretação da dialética escolástica, materializada em comentários $^{199}$.

De largas vistas intelectuaes e profundo conhecedor da sciencia juridica, bem como da grammatica, lrnerius, que Godofredo denomina o primus illuminator scientiae nostrae, iniciou seu curso de direito romano na escola de Bolonha, attrahindo, com suas doutas lições, um avultado numero de discipulos que se reuniram ao redor da sua cathedra formando a Escola dos Glosadores, cujo ascendente intelectual, no dizer de Maynz, acabou por submetter a maior parte da Europa ao dominio da legislação romana.

O nome Glosadores dado aos filiados a essa escola de jurisconsultos, foi devido ao processo exegetico pelo qual costumavam elles fazer o estudo das fontes romanas, escrevendo entre as linhas do proprio texto, ou á margem, substanciosas notas chamadas glosas interlineares ou marginaes".

197 Reynaldo PoRChAT, Curso Elementar de Direito Romano, vol. I, 2 ${ }^{\mathrm{a}}$ ed., São Paulo, Melhoramentos, 1937, p. 7:

"Dentre os discipulos notaveis dessa Escola, onde se destacavam em brilho os quatuor doctores Bulgarus, Martinus, Jacobus e Hugo, conquistou maior celebridade Accursius (...), natural de Florença, cuja alta competencia para interpretar e conciliar os textos, excedia, no dizer de Cujacio, a todos os interpretes gregos e latinos.

Elle compoz a Grande Glosa - Glossa magna, Glossa ordinaria ou Glossa Accursiana, como que uma synthese dos trabalhos feitos até então, a qual, apesar dos defeitos que se lhe notam, gosára de tão grande autoridade entre os jurisconsultos e os magistrados, que era observada nos tribunaes como lei, e por vezes invocada para vencer um texto expresso da legislação". José Reinaldo de Lima LOPES, O Direito na História - Lições Introdutórias, $4^{\mathrm{a}}$ ed., São Paulo, Atlas, 2012, p. 120:

"A escola dos glosadores determina um estilo de estudo jurídico relativa mente simples, inicial, de grande respeito ao texto romano. São os juristas do século XIV que adquirem maior liberdade. Já são senhores de um saber mais consolidado, já dispõem de mais cópias dos textos romanos, já houve um enorme avanço da legislação sobre o costume, por força da própria reforma gregoriana da Igreja. O costume, respeitabilíssimo e fonte primária da vida jurídica, pode então ser corrigido pela razão, seja ela a lei bem ordenada pela autoridade, seja a interpretação dos doutores". Reynaldo PORCHAT, Curso Elementar de Direito Romano, vol. I, $2^{\text {a }}$ ed., São Paulo, Melhoramentos, 1937, p. 8:

"Com o desenvolvimento das glosas nasceu o systema dos commentarios, que produziu a Escola dos Cornmentadores ou Postglosadores. Applicando a doutrina juridica á interpretação dos textos, esta Escola introduziu, abusivamente, nos estudos, a dialectica escolastica com as suas divisões e distincções subtis. O seu mais distincto representante foi Bartholus (...), natural de Sassoferrato, jurisconsulto de tão grande renome, que, na Hespanha e em Portugal, os tribunaes respeitavam como se fossem leis as suas opiniões". 
Alcançando o status de conselheiros dos príncipes e de pareceristas de particulares, coube também aos Comentadores a tarefa de amalgamar os diversos sistemas de direito locais difundidos com Cristianismo com o ius commune, ou seja, o direito romano erudito ou acadêmico, viabilizando a coexistência da tradição feudal com os prenúncios do modernos como comércio e a monetarização das relações jurídicas $^{200}$.

Outras escolas vieram com o passar do tempo, cabendo menção à Escola Humanista, que se forma com o Renascimento. Todavia a proeminência das Escolas de Bolonha sente-se na influência de seus discípulos na divulgação das questões jurídicas por toda a Europa, não se restringindo tão somente à investigação histórica ou ao conhecimento do direito romano clássico, mas também exercendo o desiderato de lhe conferir utilidade e interesse práticos e imediatos ${ }^{201}$.

É no século XIX na Alemanha, contudo, que o direito romano encontrou o terreno fértil para aprofundar suas raízes, sendo inclusive alçado à condição de direito vigente até a entrada em vigor do Código Civil do país em $1900^{202}$.

José Reinaldo de Lima LOPES, O Direito na História - Lições Introdutórias, $4^{\mathrm{a}}$ ed., São Paulo, Atlas, 2012, pp. 120 e 121:

"Os comentadores, a segunda escola, transformam-se nos grandes conselheiros dos príncipes, das comunas e dos particulares, emitem opiniões e pareceres (consilia) e ajudam a dar mais um passo na unificação ou, pelo menos, na harmonização dos direitos locais espalhados pela Cristandade. Eles conciliavam direitos locais entre si, pela via do direito comum, o ius commune, ou seja, o direito romano erudito, acadêmico. Eles tornaram possível também uma convivência da tradição feudal com as novas tendências da vida europeia: o comércio e a monetarização da vida e das obrigações, uma certa flexibilização nas transferências de terras e sucessões".

José Reinaldo de Lima LOPES, O Direito na História - Lições Introdutórias, $4^{\mathrm{a}}$ ed., São Paulo, Atlas, 2012, pp. 121 e 122:

"A influência da escola de Bolonha será necessariamente mais do que prática e imediata. Será cultural. Os seus alunos não se transformarão apenas em juízes, mas vão influir na cultura jurídica e filosófica em geral. Não influem apenas e diretamente na aplicação prática do direito, mas serão divulgadores, pensadores hegemônicos das questões jurídicas e políticas e criadores deste campo autônomo do saber na Europa. Suas escolas serão conhecidas como o mos italicus, a maneira italiana de estudar o direito e influirão até o século XVII, em oposição ao mos gallicus (francês, histórico, culto e sistemático) que virá a formar-se a partir do humanismo e do Renascimento.

Ao contrário dos humanistas, que valorizam a pesquisa histórica e a recuperação do texto romano puro, naquele espírito que se nota no Renascimento em geral (fins do século $\mathrm{XV}$, início do século $\mathrm{XVI}$ ), os comentadores não queriam a Antiguidade pela Antiguidade, mas para seu próprio uso e interesse. Não tinham a paixão pelo texto clássico puro, (...), mas pelo seu valor contemporâneo". Reynaldo PoRCHAT, Curso Elementar de Direito Romano, vol. I, $2^{\mathrm{a}}$ ed., São Paulo, Melhoramentos, 1937, pp. 9 e 10:

"Mas foi sobretudo na Allemanha que o direito romano encontrou propicio campo onde plantou mais profundamente as suas raizes, sendo mesmo adoptado espontanea mente - ex recepto - como direito vigente, com o nome jus commune até á promulgação do codigo civil allemão, que começou a vigorar em $1 .^{\circ}$ de janeiro de 1900". 


\section{Negócio Jurídico}

Em advertência preliminar, faz-se mister esclarecer que os jurisconsultos romanos não se ocuparam de sistematizar, em caráter geral e abstrato, acerca do negócio jurídico, sendo que essa teoria é de criação moderna ${ }^{203}$. Na realidade, remonta aos estudos dos pandectistas alemães do século XIX, que com base nas fontes do direito romano elaboraram de forma sistemática aquilo que os romanos tão somente intuíram ${ }^{204}$.

\section{a) Classificação}

A primeira distinção que se atribui aos negócios jurídicos os separa em solenes e não-solenes. Dentre os primeiros, situam-se aquelas modalidades de negócios para cuja validade a forma exigida pelo direito é elemento essencial (forma ad substanciam). Esse tipo de negócio jurídico preponderou no período pré-clássico, marcado pelo rígido formalismo, porém persistem no período clássico ao lado de outros negócios derivados do ius gentium, para os quais a forma é tão somente veículo de prova (forma ad probationem), sendo estes últimos classificados como não-solenes ${ }^{205}$.

José Augusto CeSAR, Ensaio sobre os Actos Juridicos, Campinas, Casa Genoud, 1913, p.31:

"A teoria do acto juridico é creação moderna. Alguns autores recentes teem negado a utilidade e mesmo a possibilidade de uma condensação sistematica de regras comuns a todas as especies de negocios juridicos, entre os quaes ha, dizem elles, diversidades fundamentaes. Este modo de ver é infundado. Si todos os negocios juridicios são declarações de vontade, não podem deixar de ezistir entre elles afinidades profundas. Estas se traduzem em principios geraes sobre a capacidade de ajir, a vontade e sua declaração, as nulidades, etc. (...)".

José Carlos MoreIRA Alves, Direito Romano, 15ª ed., Rio de Janeiro, Forense, 2012, pp. 157 e 158:

"A teoria dos negócios jurídicos é criação moderna: data da obra dos pandectistas alemães do século XIX. Os jurisconsultos romanos (embora haja opiniões em contrário, como a de Dulckeit) não a conheceram. No entanto, tendo em vista que essa teoria foi elaborada com base nos textos romanos, e que ela põe em relevo, de modo sistematizado, conhecimentos jurídicos de que os jurisconsultos romanos tiveram intuição, tanto que emanam de suas obras, os autores modernos geralmente a utilizam no estudo do direito romano".

José Carlos MoreIRA Alves, Direito Romano, $15^{\mathrm{a}}$ ed., Rio de Janeiro, Forense, 2012, p. 158:

"Os negócios jurídicos solenes são aqueles em que a manifestação de vontade das partes deve obedecer às formalidades exigidas pelo direito objetivo. Neles, a forma (isto é, o conjunto dessas formalidades) é elemento essencial; daí dizer-se que a forma é da substância do ato (forma ad substantiam), uma vez que, não sendo ela observada, o negócio jurídico não é válido.

Os negócios jurídicos não-solenes são aqueles em que a vontade pode manifestar-se independentemente de quaisquer formalidades. Isso não quer dizer, no entanto, que um negócio jurídico não-solene não possam as partes usar de determinada forma, para fins de prova. Nesse caso, porém, a forma utilizada não é elemento essencial do negócio jurídico; ela se destina, apenas, a facilitar posteriormente a prova de que ele se celebrou; daí dizer-se que a forma, nessa hipótese, é ad probationem.

O direito romano pré-clássico é rigidamente formalista. Os negócios jurídicos, nessa época, são solenes (assim, a stipulatio, a mancipatio, a in iure cessio). No direito clássico, em virtude do 
A solenidade característica dos negócios jurídicos fazia preponderar a forma em detrimento do conteúdo, de modo que se exigiam rituais complexos e a pronúncia de fórmulas verbais em palavras específicas, cuja inexatidão dava azo à invalidade dos negócios celebrados ${ }^{206}$.

Destaque-se que a solenidade versada não se confunde com a forma escrita, sendo que o direito romano arcaico concebeu somente negócios jurídicos orais, de forma que para conservação da sua memória e sua posterior prova eram celebrados em público ou na presença de testemunhas ou de um magistrado. Posteriormente, por influência dos gregos, é que a forma escrita passa a ser utilizada no âmbito do direito, alçando nos períodos clássico e pós-clássico, no plano prático, a condição de complemento indispensável, adquirindo, contudo, exigência legal, tão somente em 528, quando Justiniano fixa que se as partes contratantes elegessem a forma escrita para celebração da avença, esta somente seria válida caso verificada a redação do instrumento ${ }^{207}$.

caráter conservador dos romanos, vários resíduos desse formalismo persistem, e, nesse período, se encontram, lado a lado, negócios jurídicos solenes e negócios jurídicos inteiramente despidos de formalidades, criados graças ao ius gentium. (...)".

"O direito antigo era formalista, deu mais importância à forma do que ao fundo. Por isso, os atos jurídicos do direito quiritário (ius civile) exigiam formalidades complicadas, de cuja observância dependia a validade do ato e o seu consequiente efeito jurídico. Assim, os atos per aes et libram, que eram a mancipatio, o nexum e a solutio per aes et libram; os atos pela in iure cessio e a stipulatio (e semelhantes como a dotis dictio, cretio etc.). Os do primeiro grupo requeriam as formalidades de uma compra e venda real, uma troca efetiva de mercadoria contra preço, que, nos tempos primitivos, era um pedaço de metal não cunhado e que por isso tinha que ser pesado. Donde a necessidade de um porta-balança e das formalidades extrínsecas de pesagem (mesmo que simbólicas). Além disso, exigiam-se as formalidades da presença das partes, do objeto, de cinco testemunhas idôneas e do pronunciamento de certas fórmulas verbais, quase sacramentais. Os do segundo grupo, atos pela in iure cessio, requeriam a imitação de um processo e os do terceiro uma fórmula verbal, com pergunta e resposta, que gerava efeitos jurídicos, desde que pronunciadas as palavras sacramentais da maneira prescrita".

José Carlos Moreira Alves, Direito Romano, 15ª ed., Rio de Janeiro, Forense, 2012, pp. 158 e 159:

"Por outro lado, o direito romano primitivo somente conhecia negócios jurídicos celebrados oralmente. E para que se conservasse a memória desses atos, eram realizados publicamente, ou diante do povo reunido em comício, ou do magistrado, ou de testemunhas. A pouco e pouco, no entanto, graças, provavelmente, à influência grega, a forma escrita foi sendo introduzida no direito romano. No século II a.C., segundo parece, já era ela utilizada. Mas, até Justiniano, a forma escrita era meramente probatória, e não ad substantiam. É certo que, no direito clássico, e, depois, no direito pós-clássico, a praxe, decorrente dos costumes gregos, era no sentido de considerar o documento escrito como complemento indispensável à celebração dos negócios jurídicos. Entretanto, contra essa prática, juristas e imperadores (por meio de rescritos) se insurgiram, acentuando que a escrita não era necessária à perfeição do negócio jurídico, mas servia apenas para a sua prova. Aquela praxe, porém, paulatinamente, ganhou terreno, e, em 528 d.C., Justiniano estabeleceu que, quando as partes tivessem convencionado celebrar um contrato por escrito, ele só 
Outra distinção diz respeito aos negócios jurídicos causais, para os quais o direito confere os efeitos jurídicos almejados tão somente se pertinentes à causa fixada, entendida esta causa objetivamente como a função econômica e social atribuída ao negócio, e o negócios abstratos, para os quais a causa é irrelevante e os efeitos jurídicos se operam independente dela ${ }^{208}$.

Classificam-se ainda os negócios jurídicos em unilaterais e bilaterais, onerosos e gratuitos e mortis causa e inter uiuos.

Interessam, porém, ao direito romano a classificação quanto à procedência, que separa os negócios jurídicos em oriundos do ius ciuile ou do ius honorarium, conforme o ramo do direito do qual derivam seus efeitos jurídicos ${ }^{209}$. Também cabe mencionar a distinção conforme o status ciuitatis dos agentes, da mesma forma apresentando-se os negócios conforme sendo oriundos do ius ciuile, e, portanto, válidos somente para os cidadãos romanos, ou do ius gentium, podendo nestes figurar como partes também os estrangeiros $^{210}$.

\section{b) Elementos}

Podem ser apontadas três categorias de elementos dos negócios jurídicos: os essenciais, que dizem respeito à sua existência e se dividem em genéricos - estes os

se reputaria perfeito com a redação do documento. Nesses casos, a forma escrita passou a ser elemento essencial do negócio jurídico".

José Carlos MoReIRA ALVES, Direito Romano, 15ª ed., Rio de Janeiro, Forense, 2012, pp. 159 e 160:

"Assim sendo, a causa de um negócio jurídico difere dos motivos que levaram as partes a realizálo. Com efeito, a causa se determina objetivamente (é a função econômico-social que o direito objetivo atribui a determinado negócio jurídico); já o motivo se apura subjetivamente (diz respeito às razões que induzem as partes a realizar o negócio jurídico). (...).

A distinção entre causa e motivo é importante porque, em regra, a ordem jurídica não leva em consideração o último.

Conhecidas essas noções, podemos conceituar os negócios jurídicos causais e abstratos. Negócio jurídico causal é aquele em que os efeitos jurídicos dele resultantes se produzem se houver a causa. Negócio jurídico abstrato é aquele em que os efeitos dele decorrentes se produzem independentemente da causa. (...)".

209 Thomas MARKY, Curso Elementar de Direito Romano, $8^{\text {a }}$ ed., São Paulo, Saraiva, 1995, p. 51:

"No direito romano fazia-se distinção entre os atos do ius civile e os do ius honorarium, dependendo da origem dos institutos. Pertenciam ao primeiro grupo a mancipatio, a in iure cessio (institutos típicos do direito quiritário), e ao segundo os pacta praetoria (acordos sancionados pelo pretor)".

210 Thomas MARKY, Curso Elementar de Direito Romano, $8^{\text {a }}$ ed., São Paulo, Saraiva, 1995, p. 51:

"Semelhante distinção havia entre atos do ius civile e do ius gentium. Entre estes últimos podemos citar a compra e venda consensual, praticável não só pelos cidadãos romanos, como também por estrangeiros em Roma, ao passo que a mancipatio, com suas formalidades, era ato que só romanos podiam praticar". 
presentes em qualquer modalidade - e os específicos - essenciais tão somente a uma determinada espécie de negócio jurídico. Os elementos naturais estão ligados a cada espécie de negócio jurídico, podendo as partes contudo deles expressamente prescindir, enquanto os acidentais não estão previstos de forma implícita e imanente, mas podem as partes expressamente deles lançar mão e agregá-los ${ }^{211}$.

No plano geral, merecem menção os elementos essenciais genéricos e os três elementos acidentais mais comuns: a condição, o termo e o encargo.

Os elementos essenciais genéricos do negócio jurídico no direito romano são as partes capazes e legitimadas, a manifestação da vontade indene de vícios que a comprometa e o objeto lícito, possível física e juridicamente e determinado, ou, pelo menos, determinável.

O elementos acidentais podem ser inúmeros, mas dentre os mais comuns está a condição, que se traduz em acontecimento futuro e incerto, cuja ocorrência desencadeia ou paralisa os efeitos jurídicos do negócio e sob esse aspecto modernamente se divide em suspensiva e resolutiva ${ }^{212}$.

Da definição se extraem três características essenciais. Primeiro, a condição deve ser fruto da vontade das partes que subordinam os efeitos jurídicos do negócio que celebram a um acontecimento futuro e incerto, desse modo distinguindo-se o instituto da nominada conditio iuris, hipótese em que os efeitos do negócio derivam na realidade

211 Thomas MARKy, Curso Elementar de Direito Romano, $8^{\mathrm{a}}$ ed., São Paulo, Saraiva, 1995, pp. 55 a 56:

"Ainda em matéria referente ao conteúdo do ato jurídico, podemos fazer distinções a respeito de seus elementos. Estes podem ser essenciais, naturais e acidentais.

Essenciais são os elementos do conteúdo do ato jurídico sem os quais este não pode existir; são eles, portanto, necessários para sua realização. (...).

Naturais são os elementos naturalmente incluídos num ato jurídico, porque a ordem legal os considera como normalmente fazendo parte deles; conforme seu tipo. (...). Por outro lado, tais elementos naturais podem ser livremente excluídos ou modificados pelas partes interessadas, desde que o façam expressamente. (...).

O número de tais elementos acidentais dos atos jurídicos é amplíssimo, pois dependem eles da vontade das partes. Toda e qualquer cláusula secundária de um ato jurídico é elemento acidental e a vida apresenta uma variedade imensa de tais cláusulas.

Ora, entre esses inúmeros elementos acidentais, a doutrina e a legislação costumam salientar três, amplamente tratados pelos romanos e também pelos modernos. São eles a condição, o termo e o modo".

212 José Carlos MoreIRA Alves, Direito Romano, 15ª ed., Rio de Janeiro, Forense, 2012, p. 167:

"Condição é o acontecimento futuro e objetivamente incerto de que se faz depender a produção ou a cessação dos efeitos de um negócio jurídico". 
de uma prescrição do ordenamento jurídico, sendo irrelevante para tanto o arbítrio das partes $^{213}$.

O evento cuja ocorrência subordina os efeitos do negócio jurídico deve ser necessariamente futuro, o que também afasta o instituto da chamada conditio praesens uel in praeteritum collata, modalidade de cláusula que vincula os efeitos do negócio a eventos presentes ou pretéritos, eventualmente desconhecidos das partes no memento da celebração do negócio, mas que este não são capazes de condicionar ${ }^{214}$.

Por derradeiro, a condição deve necessariamente ser mercada pela incerteza quanto à verificação do evento a que se subordinou os efeitos jurídicos do negócio, porque havendo certeza, tratar-se-á de outra figura jurídica ${ }^{215}$.

Além disso, as condições também se podem distinguir em potestativas, que dependem da vontade das partes, causais, que independem dessa vontade, e mistas, que dependem da vontade de uma das partes e de uma ato de terceiro alheio ao negócio ou de um fato natural ${ }^{216}$.

213 Thomas MARKy, Curso Elementar de Direito Romano, $8^{\mathrm{a}}$ ed., São Paulo, Saraiva, 1995, p. 56:

"Em primeiro lugar, é mister que seja realmente o arbítrio das partes que subordine à ocorrência de determinada circunstância os efeitos jurídicos da manifestação da vontade. Por isso, não é condição a chamada condicio iuris. Nesta última hipótese, é o próprio direito que faz depender os efeitos do ato jurídico de uma outra circunstância, sendo irrelevante que as partes também tenham incluído cláusula cogitando do mesmo assunto. Exemplo: 'Que Tício seja meu herdeiro, se eu morrer antes dele'. A regra jurídica já prevê, como pressuposto da nomeação de herdeiro, o fato de este sobreviver ao testador. A repetição da regra jurídica não dá ao ato o caráter de ato condicionado, pois a inclusão daquele elemento não depende da vontade das partes".

214 Thomas MARKY, Curso Elementar de Direito Romano, $8^{\mathrm{a}}$ ed., São Paulo, Saraiva, 1995, p. 57:

"Em segundo lugar, o evento de que dependem os efeitos do ato jurídico deve ser futuro, isto é, deve verificar-se após a estipulação da condição pelas partes. Portanto, não é condição a condicio in praesens vel in praeteritum collata, que é a cláusula que faz depender as conseqüências do ato de evento verificado concomitantemente com a estipulação ou mesmo anteriormente a ela. Isto porque em tais casos não há pendência. $\mathrm{O}$ ato é válido ou nulo desde o início, apenas as partes podem não ter conhecimento daquele pormenor no momento da estipulação".

215 Thomas MARKY, Curso Elementar de Direito Romano, $8^{\mathrm{a}}$ ed., São Paulo, Saraiva, 1995, p. 57:

"Em terceiro lugar, é característica da condição a incerteza quanto à verificação do evento de que dependem os efeitos jurídicos do ato. Havendo certeza na verificação, mesmo que a data seja incerta, não se trata de condição, mas sim de termo, (...)".

216 José Carlos Moreira Alves, Direito Romano, 15ª ed., Rio de Janeiro, Forense, 2012, p. 169:

"As condições potestativas são as que, para se realizarem, dependem da vontade de uma das partes (por exemplo: Caio pagará cem moedas a Tício, se este subir ao Capitólio). Deve-se distinguir a condição potestativa simples da condição meramente potestativa: a primeira depende de ato ou de abstenção que limite a vontade da parte a que diz respeito (no exemplo anterior, para que Tício receba as cem moedas é preciso não apenas querer subir ao Capitólio, mas realizar esse ato); já a segunda depende exclusivamente da vontade da parte, razão por que, quando essa condição fica na dependência da vontade do devedor, não se forma o negócio jurídico, por estar, nesse caso, o devedor vinculado apenas ao seu arbítrio (exemplo: Caio, se quiser, pagará cem moedas a Tício). 
Ainda no tocante ao elemento acidental da condição é necessário retomar a distinção entre as condições suspensivas e resolutivas, primeiro porque o direito romano conheceu somente a primeira modalidade, sendo a condição resolutiva produto de estudos posteriores, e segundo, porque mesmo em Roma a matéria recebeu diferentes tratamentos conforme o período que se destaca. Como já salientado, os efeitos jurídicos do negócio subordinado à condição suspensiva até a sua ocorrência ficam em estado de latência (spes), sendo que o direito arcaico considerava o negócio jurídico nessa fase inexistente, enquanto no direito clássico inaugurou-se a dúvida nesse tocante, somente resolvida no direito pós-clássico que evolui para julgar o negócio nesse estágio existente, mas pendente, com a consequência de poder compor o patrimônio do titular dos direitos dele derivados. Outra discussão foi acerca do início da eficácia do negócio jurídico condicional após verificada a condição suspensiva, se desde a celebração (ex tunc) ou desde a ocorrência do evento suspensivo (ex nunc), sendo nesse caso a solução distinta entre o direito romano e o contemporâneo, pois naquele - no período clássico os efeitos eram desde a prática do negócio e hoje consideram-se os efeitos desde a verificação da condição ${ }^{217}$.

As condições casuais são as que independem da vontade das partes (assim: Caio pagará cem moedas a Tício, se determinado navio chegar ao porto).

As condições mistas são aquelas que dependem da vontade de uma das partes e da de um terceiro ou do acaso; por exemplo: Caio pagará dez moedas a Tício, se este se casar com Lucrécia".

"Quanto aos efeitos jurídicos, as condições podem ser constituídas de duas maneiras: ou as condições pedem suspender o efeito do ato, para que ele só tenha eficácia quando o evento se verificar, ou podem rescindir o efeito do ato. Nesse último caso, o ato tem eficácia imediatamente, cessando ela, porém, com a verificação do evento. Distinguimos, pois, a condição suspensiva e a condição resolutiva.

Note-se que o direito romano somente conheceu a condição na sua forma suspensiva. A condição resolutiva, como instituto, é do direito intermédio e do moderno.

Os efeitos da condição suspensiva se encontram em situação de pendência (condicio pendet), enquanto não se verificar o evento. Trata-se de fase de incerteza e, ao mesmo tempo, de expectativa, caracterizada pela esperança (spes). O direito pré-clássico reputava o ato nesta fase não só ineficaz, mas, também, inexistente. Já no direito clássico surgiu dúvida a esse respeito e, finalmente, o direito pós-clássico considerou como já existente o ato nesta fase de pendência. A consequiência disto foi a de considerar tal ato como fazendo parte do patrimônio de seu titular e, sendo assim, transmissível por atos entre vivos ou mortis causa.

Quando o evento da cláusula condicional se verifica (condicio existit), o ato passa a ser considerado puro, como se nunca tivesse estado sujeito à condição.

O problema que surge é o de saber quando começa a eficácia do ato: se no momento inicial da prática do ato condicionado (ex tunc) ou no momento da verificação do evento (ex nunc).

A solução é diferente no direito romano e no moderno.

O direito romano clássico considerava os efeitos do ato condicionado produzidos ex nunc; o moderno considera-os produzidos ex tunc.

Quando o evento previsto na cláusula definitivamente não se verifica (condicio deficit), o ato é considerado como se nunca tivesse existido. 
O termo é um acontecimento também futuro, mas certo, que aposto ao negócio jurídico, da sua verificação dependerão os efeitos jurídicos perseguidos pelas partes. classificava-se em Roma em suspensivo, hipótese em que até a sua ocorrência os efeitos não se produziam, e resolutivo, modalidade na qual a sua ocorrência fulminava os efeitos jurídicos do negócio celebrado.

O modo ou encargo é um elemento acidental que somente pode ser agregado aos negócios jurídicos gratuitos inter uiuos ou mortis causa, visto que se trata de uma conduta imposta pela parte que pratica a liberalidade à parte que a recebe. O encargo se diferencia da condição porque os efeitos jurídicos do negócio são imediatos, a despeito de já no direito clássico se encontrar mecanismos que forçavam a parte alvo do encargo a cumpri-lo. Esses meios eram a previsão de sanção para a hipótese de inadimplemento do encargo, a prestação de caução ou a obtenção pelos favorecidos pelo encargo de providências recobradas do magistrado e suficientes a forçar o encarregado. No direito pós-clássico a parte que praticava a liberalidade poderia recobrar o objeto em caso de inadimplemento do encargo ou propor ação judicial exigindo o seu fiel cumprimento (actio ciuilis incerti praescriptis uerbis).

Temos que mencionar, ainda, que no direito romano alguns atos, como a conventio in manum, a designação de herdeiro, a mancipação, a in iure cessio e outros atos formais, chamados actus legitimi, não admitiam cláusula de condição, sob pena de nulidade de todo o ato". 


\section{CAPÍtUlo III - O NEGócio JURÍDico NO DIREITO BRASILEIRO}

Neste ponto já aflora distinção adotada pelo atual Código Civil em relação ao anterior ${ }^{218}$. O Estatuto Civil de 1916 se alicerçava sobre o conceito de "ato jurídico" para também englobar as hipóteses de declaração volitiva aderente ao direito e capaz de gerar efeitos na órbita da autonomia privada do agente, ou seja, o "negócio jurídico"219, enquanto o Código de 2002 ao conferir ao "negócio jurídico" idêntico tratamento antes reservado ao "ato jurídico", não cuidou da definição daquele conceito, como o velho Código de 1916 fazia com este em seu art. $81^{220}, 221$.

José Carlos MoreIRA Alves, O Negócio Jurídico no Projeto de Código Civil Brasileiro - Análise Comparativa com o Código Civil Português de 1967, in A Parte Geral do Projeto de Código Civil Brasileiro - Subsídios Históricos para o Novo Código Civil Brasileiro, 2a ed., São Paulo, Saraiva, 2003, pp. 100 e 101:

"É na disciplina dos negócios jurídicos que o Projeto de Código Civil brasileiro, no tocante à sua Parte Geral, apresenta maiores alterações em face do Código Civil vigente.

Ao redigir o seu projeto, no final do século XIX, não contava Clóvis Beviláqua com os subsídios que, alguns anos mais tarde, viria a ministrar a doutrina germânica para a distinção, em categorias, dos atos jurídicos lícitos. Em 1899, a diferença entre negócio jurídico e ato jurídico em sentido estrito ainda se apresentava, até na obra dos mais eminentes romanistas e civilistas alemães, de maneira pouco precisa. (...)

Não havia, ainda, estudo mais aprofundado dessas espécies de atos jurídicos lícitos. Faltava maior precisão à linha divisória entre essas duas figuras; suas conseqüências careciam de exame.

(...)

Atento a essa circunstância, o Projeto de Código Civil brasileiro, no Livro III de sua Parte Geral, substituiu a expressão genérica ato jurídico, que se encontra no Código em vigor, pela designação específica negócio jurídico, pois é a este, e não necessariamente àquele, que se aplicam todos os preceitos ali constantes. E, no tocante aos atos jurídicos lícitos que não negócios jurídicos, abriulhes um título, com artigo único, em que se determina que se lhes apliquem, no que couber, as disposições disciplinadoras do negócio jurídico. (...).

Assim, deu-se tratamento legal ao que já se fazia, anteriormente, com base na distinção doutrinária que corresponde à natureza das coisas".

219 Caio Mário da SILVA PeREIRA, Instituições de Direito Civil - Introdução ao Direito Civil - Teoria Geral do Direito Civil, vol. I, $23^{\text {a }}$ ed. atualizada por Maria Celina Bodin de Moraes, Rio de Janeiro, Forense, 2010, pp. 408 e 409:

"O Código Civil de 1916 construía a noção de obrigação voluntária sobre a base do ato jurídico, que definiu no art. 81. O ato jurídico, tal como era entendido e estruturado, também conceitualmente se fundava na declaração de vontade, uma vez que, analisado em seus elementos, acusa a existência de uma emissão volitiva, em conformidade com a ordem legal, e tendente à produção de efeitos jurídicos. (...).

Em todo ato jurídico, sem dúvida, existe uma emissão de vontade. Mas a doutrina contemporânea manifesta certo cuidado na distinção das duas noções, admitindo a manifestação volitiva como gênero, e o negócio jurídico como espécie, porque, existindo declarações de vontade que têm em vista realizar uma finalidade jurídica, e outras não, somente as primeiras compõem o extremo do negócio jurídico. Todo ato jurídico, portanto, se origina de uma emissão de vontade, mas nem toda declaração de vontade , constitui um negócio jurídico". 
Outra alteração trazida pelo novel Estatuto de Direito Privado de 2002 foi no tocante à topologia da matéria, cuja ordem de colocação foi modificada com exclusão e inclusão de capítulos ${ }^{222}$.

"Art. 81 - Todo o ato lícito, que tenha por fim imediato adquirir, resguardar, transferir, modificar ou extinguir direitos, se denomina ato jurídico". por Ana Cristina de Barros Monteiro França Pinto, São Paulo, Saraiva, 2010, p. 219:

"Não observou o legislador de 1916 idêntica orientação quanto ao ato jurídico, por ele definido, no art. 81, como todo ato lícito que tenha por fim imediato adquirir, resguardar, transferir, modificar ou extinguir direitos. O Código de 2002 empresta ao negócio jurídico o mesmo tratamento legal que o de 1916 emprestava ao ato jurídico, embora se abstendo de defini-lo". Brasileiro - Subsídios Históricos para o Novo Código Civil Brasileiro, 2a ed., São Paulo, Saraiva, 2003, pp. 104 e 105:

"Do confronto, verifica-se que, embora conservando o mesmo número de capítulos - cinco - o Projeto não só modificou a ordem de colocação, mas também retirou um que está no Código vigente" ("Da forma dos atos jurídicos e da sua prova"), acrescentando, em contrapartida, outro que neste não se acha ("Da representação").

Exclusão e inclusão explicam-se facilmente.

Retirou-se o capítulo "Da forma dos atos jurídicos e da sua prova, porque se entendeu que a maior parte do seu conteúdo, que é referente à prova, diz respeito, em rigor, aos fatos jurídicos em sentido amplo, e não apenas aos negócios jurídicos. Daí a razão por que, no Projeto, o Título V do Livro III da Parte Geral - que se intitula "Dos fatos jurídicos" - é dedicado todo à prova. Quanto às normas concernentes à forma do negócio jurídico, e cuja sedes materiae no Código atual se encontra também no capítulo ora excluído, foram elas colocadas, no Projeto, nas "Disposições gerais", onde se estabelecem os preceitos gerais sobre os requisitos de validade do negócio jurídico, um dos quais é a forma prescrita ou não defesa em lei.

Incluíram-se, por outro lado, em capítulo próprio, na Parte Geral do Projeto, regras genéricas sobre representação legal e voluntária, suprindo-se, dessa forma, omissão do Código vigente.

(...) A colocação de matérias seguida, no particular, pelo Projeto justifica-se se se atentar para a circunstância de que, depois de se estabelecerem os requisitos de validade do negócio jurídico, trata-se de dois aspectos ligados à manifestação de vontade: a interpretação do negócio jurídico e a representação. Em seguida, disciplinam-se a condição, o termo e o encargo, que são autolimitações da vontade (isto é, uma vez apostos à manifestação de vontade, tornam-se inseparáveis dela). Finalmente, a parte patológica do negócio jurídico: defeitos e invalidade". 


\section{CAPÍTULO IV - NOVOS DEFEITOS DO NEGÓCIO JURÍDICO}

Tendo em vista que são elementos essenciais do "negócio jurídico" a declaração de vontade do agente e a subordinação dos efeitos pretendidos pelas partes declarantes ao ordenamento jurídico, exige essa mesma ordem legal que a declaração por suposto exista, porque caso contrário, inexistente será o negócio que nem sequer se formará ${ }^{223}$, e, além do mais, seja lisa e escorreita, traduzindo o exato desejo emanado do íntimo do declarante. Será, nessa medida, defeituoso o aquele "negócio jurídico" ancorado em declaração que não coincide com a vontade do declarante ou cujos efeitos pretendidos não se curvam e não se subsumem aos ditames do direito ${ }^{224}$.

Desse modo, os defeitos do negócio jurídico podem ser agrupados em duas categorias distintas, conforme o vício resida na dissonância entre a declaração externada e real vontade do declarante ${ }^{225}$ ou na distensão entre os efeitos jurídicos pretendidos por

Washington de Barros Monteiro, Curso de Direito Civil - Parte Geral, vol. 1, 42 ${ }^{\mathrm{a}}$ ed. atualizada por Ana Cristina de Barros Monteiro França Pinto, São Paulo, Saraiva, 2010, p. 233:

“(...) negócio jurídico é manifestação da vontade tendente a criar, modificar ou extinguir um direito. A vontade é, pois, base e fundamento do ato, sua razão de ser, a alma do negócio jurídico. (...)

Efetivamente, pode acontecer que a vontade não tenha existido na celebração do negócio jurídico. Tal ausência pode ser fruto das mais diversas circunstâncias, umas transitórias, como a coação absoluta, outras duradouras e permanentes, como a alienação mental. Em ambos os casos, bem como em várias situações análogas, o ato não pode subsistir, porque lhe falta o elemento básico, fundamental, a vontade do agente".

224 Caio Mário da Silva PereIRA, Instituições de Direito Civil - Introdução ao Direito Civil - Teoria Geral do Direito Civil, vol. I, $23^{\mathrm{a}}$ ed. atualizada por Maria Celina Bodin de Moraes, Rio de Janeiro, Forense, 2010, p. 439:

"O pressuposto do negócio jurídico é a declaração da vontade do agente, em conformidade com a norma legal, e visando a uma produção de efeitos jurídicos. Elemento específico é, então, a emissão de vontade. Se falta, ele não se constitui. Ao revés, se existe, origina o negócio jurídico. Mas o direito não cogita de uma declaração de vontade qualquer. Cuida de sua realidade, de sua consonância com o verdadeiro e íntimo querer do agente, e de sua submissão ao ordenamento jurídico. Na verificação do negócio jurídico, cumpre de início apurar se houve uma declaracão de vontade. E, depois, indagar se ela foi escorreita. Desde que tenha, feito uma emissão de vontade, o agente desfechou com ela a criação de um negócio jurídico. Mas o resultado, ou seja, a produção de seus efeitos jurídicos, ainda se acha na dependência da verificação das circunstâncias que a envolveram. É que pode ter ocorrido uma declaração de vontade, mas em circunstâncias tais que não traduza a verdadeira atitude volitiva do agente, ou persiga um resultado em divórcio das prescrições legais. Nesses casos, não se nega a sua existência, pois que a vontade se manifestou e o negócio jurídico chegou a constituir-se. Recusa-lhe, porém, efeitos o ordenamento jurídico". por Ana Cristina de Barros Monteiro França Pinto, São Paulo, Saraiva, 2010, p. 233:

"Pode acontecer ainda que a vontade tenha existido; o interes sado desejou realmente praticar o ato questionado; mas sua vontade estava contaminada por algum dos vícios do consentimento, erro ou ignorância, dolo e coação ou violência, estado de perigo ou lesão. Sendo o negócio jurídico pura emanação da vontade, efeito em relação à causa, é claro que ele se ressentirá dos mesmos vícios 
meio da celebração do "negócio jurídicos" e os imperativos do ordenamento normativo $^{226},{ }^{227}$. Classifica-os a doutrina, conforme a hipótese, em vícios de consentimento e vícios sociais ${ }^{228}$.

O fundamento ontológico da teoria dos defeitos do negócio jurídico deriva do fundamento ético que norteia o direito civil e os "negócios jurídicos" em especial. Sendo estes um fenômeno que se funda em dois alicerces, a declaração de vontade e submissão ao direito, qualquer rompimento deste binômio, vontade-norma legal, dará azo à invalidade do negócio já existente. Desconformidade entre a vontade declarada e a vontade real ou insubmissão dos efeitos jurídicos pretendidos por meio da celebração do

que a esta originariamente maculavam. A conseqüência natural será a ineficácia do ato eivado por qualquer daqueles vícios".

Caio Mário da Silva PEREIRA, Instituições de Direito Civil - Introdução ao Direito Civil - Teoria Geral do Direito Civil, vol. I, 23ª ed. atualizada por Maria Celina Bodin de Moraes, Rio de Janeiro, Forense, 2010, p. 440:

"São, na verdade, de duas categorias os defeitos que podem inquinar o ato negocial. Uns atingem a própria manifestação da vontade, perturbando a sua elaboração, e atuam sobre o consentimento. Por motivos vários, perturbam a própria declaração volitiva, e influem no momento em que se exterioriza a deliberação do agente. Denominam-se vícios de consentimento, em razão de se caracterizarem por influências exógenas sobre a vontade exteriorizada ou declarada, e aquilo que é ou devia ser a vontade real, se não tivessem intervindo as circunstâncias que sobre ela atuaram, provocando a distorção. Outros afetam o ato negocial, salientando a desconformidade do resultado com o imperativo da lei, e, nesses casos, o negócio reflete a vontade real do agente, canalizada, entretanto, e desde a origem, em direção oposta ao mandamento legal Nenhuma oposição se apresenta entre a vontade íntima e a vontade externada, porém entre a vontade do agente e a ordem legal. Há, portanto, um negócio jurídico, existe uma declaração de vontade, mas esta, por fatores endógenos, traduz uma volição que visa a resultados condenados ou condenáveis. Com razão, Clóvis Beviláqua os denomina vícios sociais, em oposição aos outros que são vícios do consentimento, por não estabelecerem, como estes, uma desarmonia entre o querer do agente e sua manifestação externa, mas uma insubordinação da vontade às exigências legais, no que diz respeito ao resultado querido".

227 Washington de BArros MonteIro, Curso de Direito Civil - Parte Geral, vol. 1, 42a ed. atualizada por Ana Cristina de Barros Monteiro França Pinto, São Paulo, Saraiva, 2010, pp. 233 e 234:

"Por fim, há casos em que a vontade existe e funciona normalmente. Há perfeita correspondência entre a vontade interna e a sua declaração. Entretanto, ela se desvia da lei, ou da boa-fé, e orientase no sentido de prejudicar terceiros, ou de infringir o direito. Surgem assim a simulação e a fraude contra credores, igualmente contempladas entre os defeitos dos atos jurídicos e que, como os primeiros, acarretam ineficácia do ato, sendo a simulação, porém, causa de nulidade do negócio jurídico".

Washington de Barros MonteIro, Curso de Direito Civil - Parte Geral, vol. 1, 42 ${ }^{\mathrm{a}}$ ed. atualizada por Ana Cristina de Barros Monteiro França Pinto, São Paulo, Saraiva, 2010, p. 234:

"Vemos, por conseguinte, que, dentre esses defeitos, uns se manifestam diretamente sobre a vontade, criando irredutível oposição entre o propósito íntimo do agente e sua expressão, verbal ou escrita. São eles o erro e a ignorância, o dolo e a coação ou violência, além do estado de perigo e a lesão.

Os outros, simulação e fraude contra credores, rigorosamente falando, não são vícios da vontade. Exprimindo-nos com mais precisão, diríamos que são vícios sociais, que comprometem também a ordem jurídica, pela deliberada afronta à lisura, à honestidade e à regularidade do comércio jurídico. Mas tanto aqueles como estes têm a mesma força de condenação, no sentido de induzir a anulabilidade do ato jurídico (Cód. Civil, art. 171)". 
negócio ao ordenamento ensejam a incidência de alguma das espécies de vícios disciplinadas no Código Civil ${ }^{229}$.

Embora a bibliografia seja vasta acerca do tema, ainda carece de maior aprofundamento o contraste entre as duas sistemáticas nos Diplomas Civilistas de 1916 e 2002. Com efeito, o novo Código Civil trouxe para o âmbito normativo geral duas novas modalidades de defeitos do negócio jurídico, que se inserem na categoria dos vícios do consentimento ${ }^{230}$. Cabe salientar, como já observado, que o trabalho se cinge à análise doutrinária, normativa e jurisprudencial dos fenômenos, residindo aí justamente a sua originalidade.

\section{Estado de Perigo}

O Código Civil de 2002 disciplinou no art. $156^{231}$ o estado de perigo ${ }^{232}$, hipótese de defeito do negócio jurídico caracterizada pela assunção de obrigação excessivamente

Caio Mário da Silva PereIRA, Instituições de Direito Civil - Introdução ao Direito Civil - Teoria Geral do Direito Civil, vol. I, $23^{\text {a }}$ ed. atualizada por Maria Celina Bodin de Moraes, Rio de Janeiro, Forense, 2010, pp. 441 e 442:

“(...) Tal teoria irá deduzir-se como corolário natural do fundamento ético do negócio jurídico. Este, já vimos, e mal não há em repetir, é um fenômeno de dupla causacão, pois que se origina da atuação conjunta da vontade e da lei. Quando falta a vontade, ou falta o preceito autorizador das consequiências, o negócio não chega a formar-se. Quando existe a vontade manifestada e o placet legal, constitui-se e produz seus efeitos regulares e queridos. Mas, quando é rompido o binômio vontade-norma legal, o negócio se forma, porém maculado ou inquinado de um defeito. O traço de comunicação entre todos os vícios (do consentimento e sociais), que atingem o ato negocial, situase na ruptura do equilíbrio de seus elementos essenciais.

(...)

Conformidade da declaração de vontade com a vontade real e com o ordenamento jurídico produz o negócio escorreito; desconformidade com uma ou com outro gera o negócio defeituoso. A teoria dos defeitos dos negócios jurídicos tem, então, por fundamento o desequilíbrio na atuação da vontade relativamente à sua própria declaração ou às exigências da ordem legal”. por Ana Cristina de Barros Monteiro França Pinto, São Paulo, Saraiva, 2010, p. 259:

"O Código Civil de 2002 introduziu mais duas figuras caracterizadoras de vícios do consentimento, que podem acarretar a invalidação do negócio jurídico. Não deixam de guardar semelhança com a coação, porque, tal como esta, emanam de situações que representam grave ameaça para o agente, seus bens ou entes queridos, de tal sorte que a vontade não se forma livremente: representa, na verdade, a escolha, entre dois males, do mal menor, mas que não teria sido obtido por outra forma".

231 Código Civil:

"Art. 156. Configura-se o estado de perigo quando alguém, premido da necessidade de salvar-se, ou a pessoa de sua família, de grave dano conhecido pela outra parte, assume obrigação excessivamente onerosa.

Parágrafo único. Tratando-se de pessoa não pertencente à família do declarante, o juiz decidirá segundo as circunstâncias". 
onerosa mediante declaração de vontade emitida pelo agente sob a necessidade de salvar a própria vida, do seu cônjuge, descendente, ascendente, ou de alguém a ele vinculado por laços afetivos ${ }^{233}$, restando neste último caso a aferição a cargo do Poder Judiciário conforme as circunstâncias fáticas ${ }^{234}$.

Washington de BARROS MONTEIRO enumera os requisitos para configuração do vício do negócio jurídico como sendo o fato do agente ou alguém próximo encontrar-se na iminência de sofrer um dano imediato e grave acerca do qual a outra parte tem pleno conhecimento, de modo a forçar uma declaração de vontade que dê azo à assunção de obrigação excessivamente onerosa, embora menos prejudicial ao declarante que suportar o dano iminente ${ }^{235}$.

\section{Lesão}

Definida em linhas gerais como o prejuízo que uma das partes suporta em razão da celebração de "negócio jurídico" no qual se verifica a desproporção entre as prestações avençadas, a lesão não recebeu disciplina específica no âmbito do velho

Washington de Barros Monteiro, Curso de Direito Civil - Parte Geral, vol. 1, 42 a ed. atualizada por Ana Cristina de Barros Monteiro França Pinto, São Paulo, Saraiva, 2010, p. 259:

"De acordo com o art. 156 do Código Civil de 2002, configura-se o estado de perigo quando alguém, premido pela necessidade de salvar-se, ou a pessoa de sua família, de grave dano conhecido pela outra parte, assume obrigação excessivamente onerosa. $\mathrm{O}$ estado de perigo determina desequilíbrio entre as partes, de tal sorte que uma delas se encontra em manifesta desvantagem perante a outra".

233 Caio Mário da Silva PereIRA, Instituições de Direito Civil - Introdução ao Direito Civil - Teoria Geral do Direito Civil, vol. I, 23 ${ }^{\mathrm{a}}$ ed. atualizada por Maria Celina Bodin de Moraes, Rio de Janeiro, Forense, 2010, p. 469:

“(...) É defeituosa a declaração de vontade quando uma pessoa a emite premida pela necessidade de salvar-se, ou a seu cônjuge, descendente, ascendente, ou mesmo alguém a ela ligada por laços de extrema afetividade, assumindo obrigação excessivamente onerosa. É elementar, nesta espécie, o fato de ter a outra parte conhecimento do estado de perigo". por Ana Cristina de Barros Monteiro França Pinto, São Paulo, Saraiva, 2010, p. 260:

"Acrescenta o parágrafo único que, tratando-se de pessoa não pertencente à família do declarante, o juiz decidirá segundo as circunstâncias. Realmente, pode ser que o perigo constitua ameaça não ao agente, nem a pessoa de sua família, mas a amigo muito querido, empregado antigo de grande dedicação à família, ou a quem a vítima esteja ligada por laços afetivos antigos". por Ana Cristina de Barros Monteiro França Pinto, São Paulo, Saraiva, 2010, p. 259:

"São requisitos para o reconhecimento do estado de perigo: a) o agente, ou pessoa de sua família, encontra-se prestes a sofrer grave dano; b) o dano deve ser imediato e grave; c) o dano provém de terceiro ou da outra parte, que dele tem conhecimento; d) o dano é mais oneroso que a obrigação assumida; e) esta é excessivamente onerosa, e disso a vítima tem conhecimento". 
Código Civil de 1916, sendo somente alçada à condição de defeito do negócio jurídico pelo atual Diploma Privado ${ }^{236}$.

A lesão não se caracteriza como um vício do consentimento puro, uma vez que o negócio não se macula tão somente em razão do descompasso entre a vontade declarada e a vontade real do agente, diferenciando-se do erro, da coação e do simples dolo, sendo assim chamada de vício excepcional ${ }^{237}$.

O Código Civil tratou do assunto no seu art. $157^{238}$ e adotou a noção de lesão qualificada, caracterizada pela celebração de "negócio jurídico" de forma proporcionar a outra parte vantagem exorbitante e desarrazoada, permeada pela necessidade ou inexperiência da parte lesada ou pela leviandade da parte beneficiada ${ }^{239}$.

Caio Mário da Silva PereIRA, Instituições de Direito Civil - Introdução ao Direito Civil - Teoria Geral do Direito Civil, vol. I, $23^{\mathrm{a}}$ ed. atualizada por Maria Celina Bodin de Moraes, Rio de Janeiro, Forense, 2010, pp. 465 e 466:

"Pode-se genericamente definir lesão como o prejuízo que uma pessoa sofre na conclusão de um ato negocia, resultante da desproporção existente entre as prestações das duas partes.

(...)

O Código Civil de 1916, porém, aboliu a rescisão por lesão, não obstante sobreviver ela na generalidade dos Códigos ocidentais, nos quais sofreu certa restrição, que lhe reduzia o campo de atuação ao contrato de compra e venda e à partilha.

(...)

O novo Código Civil, contrariamente ao antigo, considera a lesão como defeito do negócio jurídico, assinalando a presença do dolo de aproveitamento como elemento subjetivo; e, como elemento objetivo, o fato de uma das partes assumir obrigação manifestamente desproporcional ao valor da prestação oposta (art. 157)".

237 Caio Mário da Silva PEREIRA, Instituições de Direito Civil - Introdução ao Direito Civil - Teoria Geral do Direito Civil, vol. I, $23^{\mathrm{a}}$ ed. atualizada por Maria Celina Bodin de Moraes, Rio de Janeiro, Forense, 2010, pp. 466 e 467:

"Não é a lesão puramente um vício do consentimento, de vez que o desfazimento do negócio não tem por fundamento uma desconformidade entre a vontade real e a vontade declarada. Difere a lesão do erro em que o agente no momento da declaração de vontade tem a consciência da realidade material das circunstâncias; não há nele o emprego de artifícios por parte de alguém que procure induzir o agente a realizar o negócio jurídico; difere da coação, em que falta o processo de intimidação sobre o ânimo do agente para compeli-lo ao negócio jurídico; e tanto se distancia da fraude que nem há mister salientar a diferença. Residindo, pois, a lesão na zona limítrofe dos vícios do consentimento, por aproveitar-se o beneficiário da distorção volitiva, para lograr um lucro patrimonial excessivo, é sem dúvida defeito do negócio jurídico, embora diferente, na sua estrutura, (...), razão por que é chamado por alguns de vício excepcional”.

238 Código Civil:

“Art. 157 - Ocorre a lesão quando uma pessoa, sob premente necessidade, ou por inexperiência, se obriga a prestação manifestamente desproporcional ao valor da prestação oposta.

$\S 1^{\circ}$ Aprecia-se a desproporção das prestações segundo os valores vigentes ao tempo em que foi celebrado o negócio jurídico.

$\S 2^{\circ}$ Não se decretará a anulação do negócio, se for oferecido suplemento suficiente, ou se a parte favorecida concordar com a redução do proveito".

239 Caio Mário da Silva PEREIRA, Instituições de Direito Civil - Introdução ao Direito Civil - Teoria Geral do Direito Civil, vol. I, $23^{\mathrm{a}}$ ed. atualizada por Maria Celina Bodin de Moraes, Rio de Janeiro, Forense, 2010, p. 467: 
São fixados dois requisitos para conformação do defeito, um objetivo e outro subjetivo $^{240}$. O primeiro consiste na desproporção anômala das prestações assumidas, sendo que diferente de outras legislações, o Código Civil não adotou o critério do tarifamento, mas optou pela dicção “prestação manifestamente desproporcional", deixando ao critério do Poder Judiciário o seu exato dimensionamento ${ }^{241}$. O requisito subjetivo consiste chamado dolo de aproveitamento, não sendo necessário que a parte beneficiária da prestação exorbitante induza a outra à celebração do negócio, mas bastando que se aproveite da situação de necessidade de realização do "negócio jurídico", inexperiência da parte lesada ou ostente leviandade no momento da celebração da avença $^{242}$.

"Segundo a noção corrente, que o nosso direito adotou, a lesão qualificada ocorre quando o agente, premido pela necessidade, induzido pela inexperiência ou conduzido pela leviandade, realiza um negócio jurídico que proporciona à outra parte um lucro patrimonial desarrazoado ou exorbitante da normalidade".

Washington de Barros Monteiro, Curso de Direito Civil - Parte Geral, vol. 1, 42 ${ }^{\mathrm{a}}$ ed. atualizada por Ana Cristina de Barros Monteiro França Pinto, São Paulo, Saraiva, 2010, pp. 261 e 262:

"Assim, não se restringiu o Código de 2002 a aplicar o instituto apenas à compra e venda, estendendo-o a qualquer contrato em que estejam presentes os pressupostos do art. 157: o primeiro, de caráter objetivo, está centrado no objeto, para logo despontando a disparidade entre as prestações devidas pelas partes, uma das quais obtém vantagem excepcional, sem correspondência do outro contratante. Não há previsão na lei do montante a que deve chegar a desproporção causadora da invalidade do negócio jurídico, mas deve ser excessiva, facilmente detectada por qualquer um que tome ciência do negócio, ficando ao prudente arbítrio do julgador o seu reconhecimento. O segundo elemento, subjetivo, por muitos denominado "dolo de aproveitamento", é pertinente à inexperiência da parte, sua ingenuidade, circunstâncias que, conhecidas do outro contratante, levam-no a procurar o ganho desmesurado à custa do despreparo da outra. Tal inexperiência deve apresentar-se como efetiva hipossuficiência naquela concreta situação em que as partes se encontram".

Caio Mário da Silva PereIRA, Instituições de Direito Civil - Introdução ao Direito Civil - Teoria Geral do Direito Civil, vol. I, $23^{\mathrm{a}}$ ed. atualizada por Maria Celina Bodin de Moraes, Rio de Janeiro, Forense, 2010, pp. 467 e 468 :

"Na sua caracterização devem ser apurados dois requisitos: um objetivo e outro subjetivo. O primeiro, objetivo, situa-se na desproporção evidente e anormal das prestações, quando uma das partes aufere ou tem possibilidade de auferir do negócio um lucro desabusadamente maior do que a prestação que pagou ou prometeu, aferida ao tempo mesmo do contrato. (...)

O Código abandona o critério do tarifamento, que sempre nos pareceu inconveniente, pois mais aconselhável é deixar ao prudente arbítrio do juiz verificar se o iustum contrapassum entre as prestações recíprocas foi sacrificado. Exige, contudo, que a prestação a que se tenha obrigado o declarante seja manifestamente desproporcional ao valor da contraprestação recebida ou prometida. Não cabe, obviamente, colocar as questões em termos de se apurar o justo preço, pois que os valores das coisas oscilam ao sabor de um conjunto de circunstâncias. Desprezou, igualmente, o conceito de valor corrente, que constitui um conceito sem a necessária rigidez. Oferece, todavia, um elemento de relativa objetividade, ao estabelecer que à lesão há de concorrer a prestação manifestamente desproporcional, isto é, uma prestação , cujo valor se distancia grandemente, evidentemente, da contraprestação".

242 Caio Mário da Silva PereIRA, Instituições de Direito Civil - Introdução ao Direito Civil - Teoria Geral do Direito Civil, vol. I, 23 ${ }^{a}$ ed. atualizada por Maria Celina Bodin de Moraes, Rio de Janeiro, Forense, 2010, p. 468: 
Preenchidos os requisitos objetivo e subjetivo, restará o "negócio jurídico" passível de anulação e, portanto, de desfazimento, uma vez que o Código Civil inquinou os negócios viciados pela lesão com a sanção da anulabilidade e não com a nulidade de pleno direito. Nessa medida, por outro lado, dispôs também que ele pode ser convalidado por meio de suplementação da prestação desproporcional ou redução do proveito exorbitante, ambas as possibilidades capazes de restabelecer a justiça comutativa do negócio ${ }^{243}$.

"O segundo requisito, subjetivo, é o que a doutrina denomina dolo de aproveitamento, e se configura na circunstância de uma das partes aproveitar-se das condições em que se encontre a outra, acentuadamente a sua inexperiência, a sua leviandade ou o estado de premente necessidade em que se acha, no momento de contratar. A necessidade, como a inexperiência apuram-se no momento e em face da natureza do negócio jurídico realizado, independentemente de não se verificarem em outras circunstâncias e para os negócios em geral. A aferição do dolo de aproveitamento, oriunda da necessidade contratual (e não necessidade no sentido de miséria, penúria, insuficiência de meios de subsistência ou manutenção), ou da inexperiência, bem como da desproporção das prestações, hão de ser contemporâneas da celebração do ato. Se em outro momento e em circunstâncias diferentes o agente não é necessitado ou inexperiente, ou se o valor da prestação recebida se distancia da prestação paga ou prometida, por força de outras circunstâncias (depreciação do valor da moeda, realização de obras ou melhoramentos beneficiando a coisa), e venha a ocorrer desproporção manifesta, não há falar em lesão (Código Civil, art. $157, \S 1^{\circ}$ ).

Não há mister que o beneficiado induza o agente a praticar o ato, levando-o à emissão de vontade por algum processo de convencimento, nem que tenha a intenção de explorá-lo. Basta que se aproveite conscientemente daquela situação de inferioridade, ainda que momentânea do agente, e com ele realize negócio de que aufira lucro anormal". Geral do Direito Civil, vol. I, $23^{\mathrm{a}}$ ed. atualizada por Maria Celina Bodin de Moraes, Rio de Janeiro, Forense, 2010, p. 468:

"Verificada a existência destes dois extremos, o ato negocial é defeituoso, e, como tal, suscetível de desfazimento. A lesão, como defeito do negócio jurídico, conduz à sua anulabilidade, e não à sua nulidade. Em conseqüência, pode ele ser convalidado. Partindo de que o fundamento da invalidação é o atentado à justiça comutativa, pode o beneficiado restabelecê-la de duas maneiras: oferecendo suplemento que desfaça a desproporção das prestações ou acordando com a redução do proveito (art. $157, \S 2^{\circ}$ ). Tendo em vista que numa ou noutra hipótese a anulação do negócio não será pronunciada, entende-se que, mesmo depois de instaurada a instância processual, caberá ao demandado oferecer suplemento suficiente ou aceitar a redução do proveito, e, com isto, ilidir a prestação anulatória do lesado". 


\section{BIBLIOGRAFIA}

Abreu, José, O Negócio Jurídico e sua Teoria Geral, 2a ed., São Paulo, Saraiva, 1988.

Alves, João Luiz, Codigo Civil da Republica dos Estados Unidos do Brasil - Annotado, Rio de Janeiro, F. Briguiet e Cia., 1917.

AuriCCHIO, Alberto, La Simulazione nel Negozio Giuridico, trad. port. de Fernando de Miranda, A Simulação no Negócio Jurídico - Premissas Gerais, Coimbra, Coimbra, 1964.

AzEvedo, Álvaro Villaça (coord.), Código Civil Comentado - Negócio Jurídico. Atos Jurídicos Lícitos. Atos Ilícitos - Artigos 104 a 188, vol. II, São Paulo, Atlas, 2003.

, Teoria Geral das Obrigações e Responsabilidade Civil - Curso de Direito Civil, 12a ed., São Paulo, Atlas, 2011.

Azevedo, Antônio Junqueira de, Estudos e Pareceres de Direito Privado, São Paulo, Saraiva, 2004.

Negócio Jurídico - Existência, Validade e Eficácia, 4ª ed., São Paulo, Saraiva, 2007.

, Novos Estudos e Pareceres de Direito Privado, São Paulo, Saraiva, 2009.

Barros Monteiro, Washington de, e França Pinto, Ana Cristina de Barros Monteiro, Curso de Direito Civil - Parte Geral, vol. 1, 42ª ed., São Paulo, Saraiva, 2010.

Batalha, Wilson de Souza Campos, Defeitos dos Negócios Jurídicos, Rio de Janeiro, Forense, 1985.

Betti, Emílio, Teoria General del Negozio Giuridico, trad. port. de Fernando de Miranda, Teoria Geral do Negócio Jurídico, Tomos I e II, Coimbra, Coimbra, 1969.

Bevilaqua, Clovis, Direito das Obrigações, Bahia, Livraria Magalhães, 1896. , Projecto de Codigo Civil Brazileiro, Rio de Janeiro, Imprensa Nacional, 1900. 
Codigo Civil dos Estados Unidos do Brazil, vol. I, Rio de Janeiro, Francisco Alves, 1916. , Teoria Geral do Direito Civil, $7^{\mathrm{a}}$ ed. atual. Achilles Bevilaqua e Isaias Bevilaqua, Rio de Janeiro, Francisco Alves, 1955.

BitTar, Carlos Alberto, Os Direitos da Personalidade, $3^{\mathrm{a}}$ ed., Rio de Janeiro, Forense Universitária, 1999.

, Teoria Geral do Direito Civil, $2^{\mathrm{a}}$ ed., Rio de Janeiro, Forense Universitária, 2007.

Campos, Francisco, Direito Civil, Rio de Janeiro, Freitas Bastos, 1956.

Cariota Ferrara, Luigi, Il Negozio Giuridico nel Diritto Privato Italiano, trad. esp. Manuel Albaladejo, El Negocio Jurídico, Madrid, Aguilar, 1956.

Carvalho Santos, J. M., Codigo Civil Brasileiro Interpretado - Principalmente sobre o ponto de vista pratico - Introdução e Parte Geral (arts. 1 - 42), vol. I, Rio de Janeiro, Calvino Filho, 1934.

, Codigo Civil Brasileiro Interpretado - Principalmente sobre o ponto de vista pratico - Parte Geral (arts. 43 - 113), vol. II, Rio de Janeiro, Calvino Filho, 1934.

, Codigo Civil Brasileiro Interpretado - Principalmente sobre o ponto de vista pratico - Parte Geral (arts. 114 - 179), vol. III, Rio de Janeiro, Calvino Filho, 1934.

, Pareceres, Rio de Janeiro, Borsoi, 1963.

CESAR, José Augusto, Ensaio sobre os Actos Juridicos, Campinas, Casa Genoud, 1913.

Coelho Da Rocha, M. A., Instituições de Direito Civil, Tomo I, São Paulo, Saraiva, 1984.

, Instituições de Direito Civil, Tomo II, São Paulo, Saraiva, 1984.

Couto e Silva, Clóvis V. do, A Obrigação como Processo, Rio de Janeiro, FGV, 2006. 
Cunha Gonçalves, Luiz da, Princípios de Direito Civil Luso-Brasileiro - Parte Geral - Dos Direitos Reais ou Direitos sôbre as Cousas, vol. I, São Paulo, Max Limonad, 1951.

Ferrara, Francisco, A Simulação dos Negócios Jurídicos, trad. port de A. Bossa, São Paulo, Saraiva, 1939.

Flume, Werner, Allgemeiner Teil des Bürgerlichen Rechts. Zweiter Band, Das Rechtsgeschäft. Vierte, unveränderte Auflage Enzyklopädie der Rechts - und Staatswissenschaft, 1992, trad. esp. de José María Miquel González e Esther Gómez Calle, El Negocio Jurídico - Parte General del Derecho Civil, Tomo Segundo, $4^{\mathrm{a} e d .,}$ Madrid, Fundación Cultural del Notariado, 1998.

GoMes, Orlando, A Crise do Direito, São Paulo, Max Limonad, 1955.

, Direito Privado - Novos Aspectos, Rio de Janeiro, Freitas Bastos, 1961.

, Memória Justificativa do Anteprojeto de Reforma do Código Civil, Rio de Janeiro, Imprensa Nacional, 1963.

, A Reforma do Código Civil, São Paulo, Universidade da Bahia, 1965. , Transformações Gerais do Direito das Obrigações, São Paulo, RT, 1967. , Questões de Direito Civil - Pareceres, 4ª ed., São Paulo, Saraiva, 1976. , Novas Questões de Direito Civil, São Paulo, Saraiva, 1979. , Escritos Menores, São Paulo, Saraiva, 1981.

, Novíssimas Questões de Direito Civil, São Paulo, Saraiva, 1984.

, Ensaios de Direito Civil e de Direito do Trabalho, Rio de Janeiro, Aide, 1986.

Questões mais Recentes de Direito Privado - Pareceres, São Paulo, Saraiva, 1988.

KELSEN, Hans, Reine Rechtslehre, 1960, trad. port. de João Batista Machado, Teoria Pura do Direito, 6ª ed., São Paulo, Martins Fontes, 1999. 
, Reine Rechtslehre, 1934, trad. port. de J. Cretella Jr. e Agnes Cretella, Teoria Pura do Direito - Introdução à Problemática Científica do Direito - Versão Condensada pelo Próprio Autor, $4^{\mathrm{a}}$ ed., São Paulo, RT, 2006.

, Hans Kelsen Selbstzeugnis, 1947, trad. port. de Gabriel Nogueira Dias e

José Ignácio Coelho Mendes Neto, Autobiografia de Hans Kelsen, $2^{\mathrm{a}}$ ed., Rio de Janeiro, Forense Universitária, 2011.

MaLuf, Carlos Alberto Dabus, A Transação no Direito Civil, São Paulo, Saraiva, 1985.

Maluf, Carlos Alberto Dabus, Cláusulas de Inalienabilidade, Incomunicabilidade e Impenhorabilidade, 4ªed., São Paulo, RT, 2006.

Mazeaud, Henri y Léon e Mazeaud, Jean, Leçons de Droit Civil, trad. esp. de Luis Alcalá-Zamora y Castillo, Lecciones de Derecho Civil - Parte Pimera - Introdución AL Estudio del Derecho Privado Dercho Objetivo Derechos Subjetivos, Vol. I, Buenos Aires, Europa-América, 1959.

Mazeaud, Henri y Léon e Mazeaud, Jean, Leçons de Droit Civil, trad. esp. de Luis Alcalá-Zamora y Castillo, Lecciones de Derecho Civil - Parte Segunda - Obligaciones: El Contrato, La Promesa Unilateral, Vol. I, Buenos Aires, Europa-América, 1960.

Miranda, Custódio da Piedade Ubaldino, A Simulação no Direito Civil Brasileiro, São Paulo, Saraiva, 1980.

Miranda, Custódio da Piedade Ubaldino, Teoria Geral do Negócio Jurídico, $2^{\mathrm{a}}$ ed., São Paulo, Atlas, 2009.

Miranda, Pontes, Tratado de Direito Privado - Parte Geral - Bens. Fatos Jurídicos,

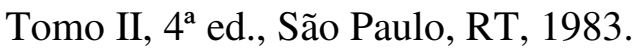

Miranda, Pontes, Tratado de Direito Privado - Parte Geral - Negócios Jurídicos. Representação. Conteúdo. Forma. Prova, Tomo III, $4^{\text {a }}$ ed., São Paulo, RT, 1983.

Miranda, Pontes, Tratado de Direito Privado - Parte Geral - Validade. Nulidade. Anulabilidade, Tomo IV, $4^{\mathrm{a}}$ ed., São Paulo, RT, 1983. 
Miranda, Pontes, Tratado de Direito Privado - Parte Geral - Eficácia Jurídica. Determinações Inexas e Anexas. Direitos. Pretensões. Ações, Tomo V, $4^{\mathrm{a}}$ ed., São Paulo, RT, 1983.

Moreira Alves, José Carlos, A Parte Geral do Projeto de Código Civil Brasileiro Subsídios Históricos para o Novo Código Civil Brasileiro, 2a ed., São Paulo, Saraiva, 2003.

Nonato, Orosimbo, Da Coação como Defeito do Ato Jurídico - Ensaio, Rio de Janeiro, Forense, 1957.

Nonato, Orosimbo, Fraude Contra Credores - Da Ação Pauliana, Rio de Janeiro, Jurídica e Universitária, 1969.

OliverRA, Eduardo Ribeiro de, Comentários ao Novo Código Civil - Dos Bens. Dos Fatos Jurídicos. Do Negócio Jurídico. Disposições Gerais. Da Representação. Da Condição. Do Termo e do Encargo, Vol. II (Arts. 79 a 137), Rio de Janeiro, Forense, 2008.

RÁo, Vicente, Ato Jurídico, $2^{a}$ ed., São Paulo, Max Limonad, 1961.

Rodrigues, Sílvio, Direito Civil - Parte Geral, vol. 1, 34ª ed., São Paulo, Saraiva, 2007.

San Tiago Dantas, Francisco Clementino, Programa de Direito Civil - Aulas proferidas na Faculdade Nacional de Direito [1942-1945] - Parte Geral, 2ª ed., Rio de Janeiro, Rio, 1979.

, Figuras do Direito, 2a ed., Rio de Janeiro, Forense, 2002.

SAntos, José Beleza dos, A Simulação em Direito Civil, 2ª ed., São Paulo, Lejus, 1999.

Silva PereIRA, Caio Mário da, Instituições de Direito Civil - Introdução ao Direito Civil - Teoria Geral de Direito Civil, vol. I, 23 ${ }^{\mathrm{a}}$ ed. atual. Maria Celina Bodin de Moraes, Rio de Janeiro, Forense, 2010.

, Obrigações e Contratos - Pareceres de acordo com o Código Civil de 2002, Rio de Janeiro, Forense, 2011. 
Tavares, José, Os Princípios Fundamentais do Direito Civil, Vol. I, Coimbra, Coimbra, 1922.

Telles Junior, Goffredo, Estudos, São Paulo, Juarez de Oliveira, 2005.

TheOdoro Júnior, Humberto, Fraude Contra Credores - A Natureza da Sentença Pauliana, Belo Horizonte, Del Rey, 1996.

TheOdoro Júnior, Humberto, Comentários ao Novo Código Civil - Livro III - Dos Fatos Jurídicos: Do Negócio Jurídico, Vol. III, Tomo I (Arts. 138 a 184), 4ª ed., Rio de Janeiro, Forense, 2008. 